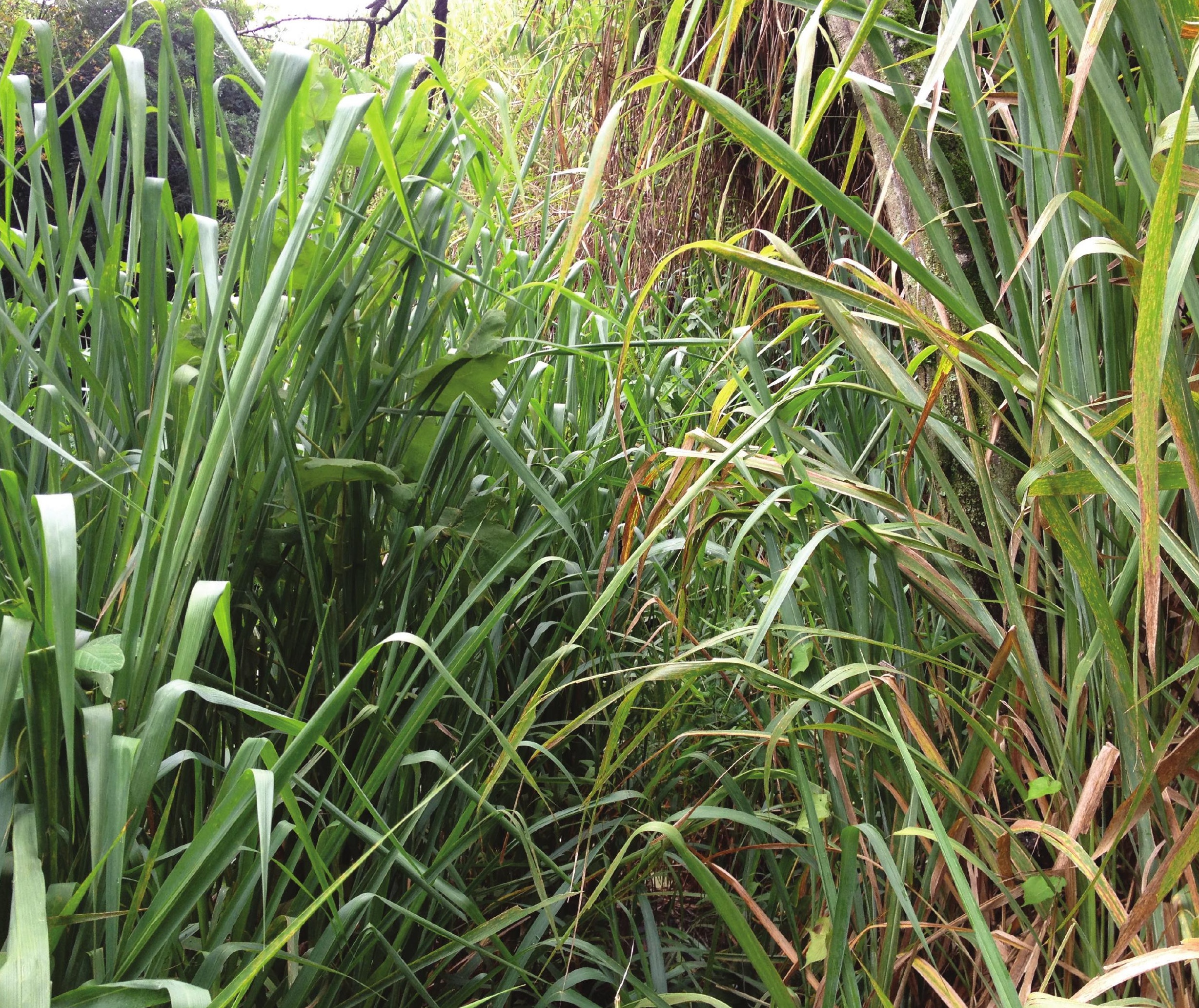





\author{
Vânia Medeiros Moreira
}

\title{
CIDADE PASSO
}

\section{Conversações entre arte, design e etnografia}

Dissertação apresentada à Faculdade de Arquitetura e Urbanismo da Universidade de São Paulo para obtenção do título de Mestre em Ciências

Programa de Arquitetura e Urbanismo

Área de Concentração: Design e Arquitetura

Orientadora: Prof ${ }^{a}$. Dr ${ }^{\mathrm{a}}$. Lara Leite Barbosa de Senne

São Paulo

2017 
Autorizo a reprodução e divulgação total ou parcial deste trabalho, por qualquer meio convencional ou eletrônico, para fins de estudo e pesquisa, desde que citada a fonte.

E-MAIL DA AUTORA: vanymedeiros@gmail.com

\begin{tabular}{|l|}
\hline Moreira, Vânia Medeiros \\
Cidade passo. Conversações entre arte, design e \\
etnografia / Vânia Medeiros Moreira. -- São Paulo, 2017. \\
109 p. : il. + anexo \\
Dissertação (Mestrado - Área de Concentração: Design e \\
Arquitetura) - FAUUSP. \\
Orientadora: Lara Leite Barbosa de Senne \\
1.Arquitetura 2.Design 3.Artes 4.Etnografia 5.Cartografia \\
6.Livros de artistas 7.Nomadismo 8.Mapas subjetivos I.Título \\
CDU 912
\end{tabular}


Nome: MOREIRA, Vânia Medeiros

Título: Cidade Passo. Conversações entre arte, design e etnografia

Aprovado em:

Dissertação apresentada à Faculdade de Arquitetura e

Urbanismo da Universidade de São Paulo para obtenção do título de Mestre em Ciências

\section{Banca Examinadora}

$\begin{array}{ll}\text { Prof. Dr. } & \text { Instituição: } \\ \text { Julgamento: } & \text { Assinatura: } \\ \text { Prof. Dr. } & \text { Instituição: } \\ \text { Julgamento: } & \text { Assinatura: } \\ \text { Prof. Dr. } & \text { Instituição: } \\ \text { Julgamento: } & \text { Assinatura: }\end{array}$


Dedico às pessoas lentas, distraídas, vagabundas, nômades, perdidas, à deriva na cidade de São Paulo, que descobrem, cotidianamente, em si mesmas e nas ruas, valiosos e secretos espaços vazios. 


\section{AGRADECIMENTOS}

À Fapesp - Fundação de amparo à pesquisa do Estado de São Paulo - cujo financiamento permitiu dedicação com profundidade à realização deste trabalho.

À minha orientadora Lara Leite Barbosa de Senne, que com sua confiança e generosidade, me encorajou a desenvolver essa pesquisa-ação com liberdade, equilibrando intuição e disciplina.

À Andrezina, minha mãe, pelo apoio confiante e amor incondicional, fundamental em tudo o que faço; a minhas irmãs Claudia e Mônica, parceiras imprescindíveis, amorosas e firmes em todos os momentos.

A Paul, meu amor, meu companheiro de viagem.

Agradeço com enorme carinho a meus entrevistados-caminhantes Zé Valdir, Ivani, Padre Enivaldo, Sandra, Felipe Julián, Anahi, Regina, Glauco, Dedê, Vinícius, Felipe Baldino, Fagner, Wesllen, Gustavo e Enilda, que me conduziram pelos percursos que dão forma ao livro Cidade Passo.

Gostaria de citar o nome de cada pessoa que faz parte da minha vasta rede de afetos, que desenham meu mapa-do-desejo onde Salvador e São Paulo fazem fronteira e são ponte pra um resto-do-mundo que é campo fértil de utopia e possibilidades. Mas são tantos nomes e a chance de esquecer apenas um deles me faz deixar em aberto essa declaração de amor! Gratidão sem limites! 
Os passos que dá um homem, desde o dia de seu nascimento até o da sua morte, desenham no tempo uma inconcebível figura. A Inteligência Divina intui essa figura imediatamente, como a dos homens um triângulo. Esse desenho tem (quem sabe) sua determinada função na economia do universo.

Jorge Luis Borges 


\section{RESUMO}

A dissertação propõe um estudo teórico-prático sobre a importância dos mapas subjetivos realizados por criadores de diversas áreas como dispositivos "táticos", capazes de propor conhecimento sobre o espaço para além da visão panóptica e impessoal da cartografia tradicional. Busca-se com a pesquisa, refletir sobre como ações de deriva e errância e seu posterior "mapa-como-relato", em diversos formatos, permitem arquitetar um espaço-tempo nômade dentro da cidade, capaz de ressignificar as relações que o indivíduo - tanto o próprio criador quanto o público/leitor/usuário - tem com a urbe. Isto ocorre uma vez que os caminhos percorridos, o "entre", é tido como um valor em si, para além dos pontos de chegada, o que cria brechas nos ditames do tempo veloz e funcional, promovendo situações de amabilidade, fruição e reflexão. Tomo como referência os mapas e livros produzidos por Guy Debord e Asger Jorn no contexto Situacionista, os livros Les dormeurs e Suite Vénitienne da artista francesa Sophie Calle, o Guia de terrenos baldios de São Paulo, de Lara Almarcegui e a trilogia I got up, I went e I met do artista conceitual japonês On Kawara. A investigação teórica se dá paralelamente à produção de um experimento prático, a criação do livro Cidade Passo, que traz o conteúdo de quinze entrevistas com moradores de cinco bairros de São Paulo em um projeto gráfico que traz à tona, visualmente, os aspectos conceituais que permeiam a pesquisa.

Palavras-chave: Arquitetura. Design. Arte. Etnografia. Nomadismo. Livro de artista. Cartografia. Mapas subjetivos. 


\section{ABSTRACT}

The dissertation proposes a theoretical-practical study about the importance of subjective maps made by creators of diverse areas as "tactical" devices capable of proposing knowledge about space beyond the panoptic and impersonal vision of traditional cartography. It seeks to reflect on how actions of drift and wandering and its subsequent "map-as-reporting", in various formats, allow the architecting of a nomadic space-time within the city, able to re-signify the relations that the individual - both the creator himself and the audience / reader / user - have with the city. This occurs because the path is taken as a value in itself, beyond the points of arrival, which creates breaches in the dictates of fast and functional time, promoting situations of kindness, fruition and reflection. I take as a reference the maps and books produced by Guy Debord and Asger Jorn in the Situationist context, the books Les dormeurs e Suite Vénitienne of the French artist Sophie Calle, The Guide of vacant lots of São Paulo (2006), by Lara Almarcegui and the trilogy I got up, I went and I met of the Japanese conceptual artist On Kawara. The research goes hand in hand with the production of a practical experiment, the creation of the book Cidade Passo, which brings the content of fifteen interviews with residents of five districts of São Paulo in a graphic project that brings to the surface visually the conceptual aspects that permeate research.

Keywords: Architecture. Design. Art. Ethnography. Nomadism. Artist's book. Cartography. Subjective maps. 


\section{SUMÁRIO}

Chãonhe-ser-me 15

Do espaço à imagem, da imagem à experiência 23

Cidade Nômade 49

Devir-artista, devir-etnógrafa, devir-designer 63

Para um novo começo 99

Referências 107

\section{ANEXO}

Livro Cidade Passo 


\section{1. chãonhe-ser-me}




\section{apetece-me des-ser-me; reatribuir-me a átomo. cuspir castanhos grãos mas gargantadentro; isto seja: engolir-me para mim poucochinho cada ve: um por mais um: areios. assim esculpir-me a barro e re-ser chão. muito chão. apetece-me chãonhe-ser-me.}

(Ondjaki, “Há prendisajens com o xão”)

A palavra "passo", possui significados ambivalentes na língua portuguesa. No sentido corriqueiro, significa "espaço percorrido cada vez que se estende ou se põe um pé diante do outro" ou "ato de passar de uma parte para outra". ${ }^{1}$ Existe ainda uma coincidência sonora com o termo "paço", usado para designar palácio, residência da corte. Dentre as pessoas dos sertões do Brasil, que têm a escrita mais ligada à sonoridade oral da língua, "passo" seria uma corruptela de "pássaro", como vemos nos versos de Patativa do Assaré, poeta popular cearense e nos de Cora Coralina, poetisa goiana.

"O sofreu e a patativa

Com o canaro e o campina

Tem canto que me cativa,

Tem musga que me domina,

E inda mais o sabiá,

Que tem premêro lugá,

É o chefe dos serestêro,

Passo nenhum the condena,

Ele é dos musgo da pena

O maió do mundo intêro."

\section{(Patativa do Assaré, "O sabiá e o gavião")}

1 "Passo", in Dicionário Priberam da Língua Portuguesa [em linha], 2008-2013, http://www.priberam.pt/dlpo/passo [consultado em 28-06-2016] 
“Ou no Evém a perseguição:

o bichinho anônimo que espia, pressente.

A formiga-cortadeira - quenquém.

A ratinha do chão, exploradeira.

A rosca vigilante na rodilha.

O passo-preto vagabundo, galhofeiro, vaiando, sirrindo...

aos gritos arrancando, mal aponta.

O cupim clandestino roendo, minando, só de ruindade."

\section{(Cora Coralina, "Poema do milho")}

Proceder através do passo neste trabalho, situa-se na busca por uma reflexão sobre os limites de três campos de conhecimento: arte, design e etnografia. Cidade Passo - Conversações entre arte, design e etnografia desdobra-se num plano de devires, de composição, que busca traçar relações ao invés de conclusões. "Um lugar onde a geografia é mais importante que a história", onde o meio é mais importante que o começo ou o fim (DELEUZE; PARNET, 1998, p.33).

Deleuze e Guattari (1997, p.18) explicam que um “devir" é, primeiramente, uma extrema proximidade que abarca duas sensações distintas. Algo que passa de um corpo a outro e que só pode ser percebido pela sensação. Uma região de indeterminações, "onde animais, pessoas ou coisas atingem um ponto infinito que antecede aquilo que faz sua diferenciação natural” (DELEUZE; GUATTARI, 1992, p. 225). Ele não deve ser encarado como uma filiação, mas como uma aliança. Os devires em Cidade Passo criam uma realidade onde há uma coexistência de elementos da arte, do design e da etnografia, em uma aliança rizomática composta de multiplicidades que fazem parte de um processo de desejo. Devir-arte, devir-design, devir-etnografia operam em uma zona de vizinhança, de copresença de partículas. Arte não se torna design e vice-versa, ambos tampouco tornam-se etnografia, mas os três entram em uma relação de movimento e repouso em uma zona de indiscernibilidade. 
Artes visuais e design são oficialmente áreas de conhecimento distintos que, ao longo da história contemporânea apresentam diversos e incessantes pontos de interseções e analogias, estabelecem trocas e conexões, que marcam a cultura visual desde o início do século XX. São campos contíguos que, por vezes, se aproximam e se assemelham, se entrecruzam e se fundem, assim como por outras, se distanciam e se separam (COSTA, 2009, p.2). Nas palavras de Flusser:

A Cultura moderna, burguesa, fez uma separação brusca entre o mundo das artes e o mundo da técnica e das máquinas, de modo que a cultura se dividiu em dois ramos estranhos entre si: por um lado, o ramo científico, quantitatível, "duro", e por outro o ramo estético, qualificador, "brando". Essa separação desastrosa começou a se tornar insustentável no final do século XIX. A palavra design entrou nessa brecha como uma espécie de ponte entre esses dois mundos. E isso foi possível porque essa palavra exprime a conexão interna entre técnica e arte. E por isso design significa aproximadamente aquele lugar em que arte e técnica (e, conseqüentemente, pensamentos, valorativo e científico) caminham juntas, com pesos equivalentes, tornando possível uma nova forma de cultura (FLUSSER, 2007, p.184).

A respeito da etnografia, Sylvia Caiuby destaca a importância da imagem (neste caso, especificamente a imagem fotográfica) como ponte entre arte, conhecimento e informação, conectando o visível e o invisível, para além de seus aspectos referenciais, por meio de uma expressividade lírica (CAIUBY, 2015, p. 10). Seu potencial de engendrar um "terceiro espaço", que não se situa exatamente nem no universo da fantasia nem propriamente no da realidade compartilhada, confere à fotografia uma essência híbrida.

[...]a história da fotografia, desde sua origem, baseia-se num equívoco estranho que tem a ver com sua dupla natureza de arte mecânica, o de ser um instrumento preciso e infalível como uma ciência e, ao mesmo tempo, inexato e falso como a arte. A fotografia, em outras palavras, encarna a forma híbrida de uma "arte exata" e, ao mesmo tempo, uma ciência artística, o que não tem equivalente no pensamento ocidental (CAIUBY, 2015, p. 14). 


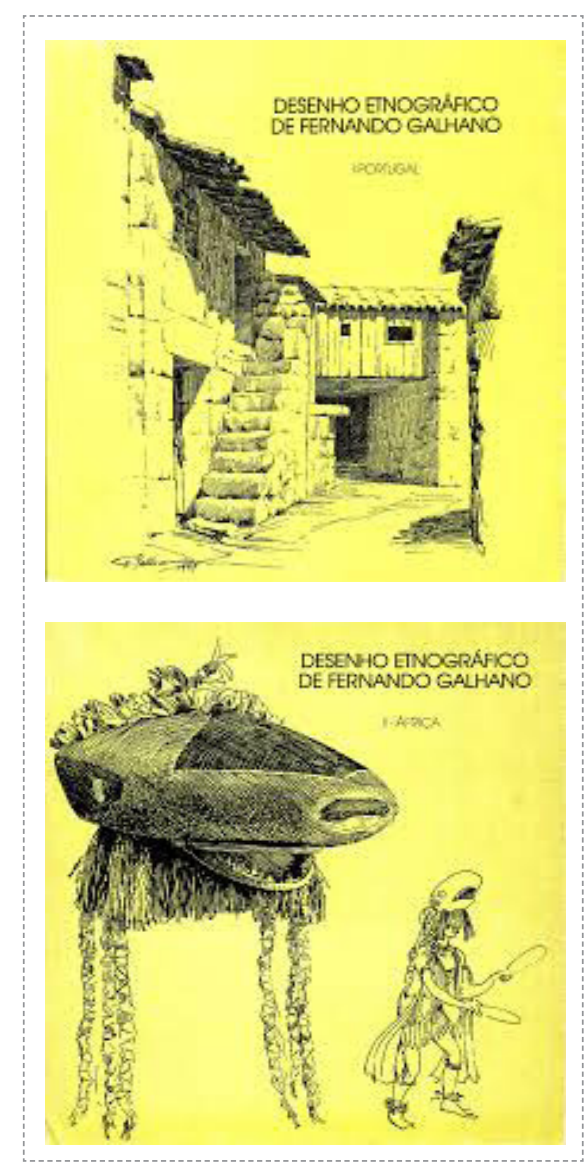

Figura 1 - Desenbo Etnográfico de Fernando Galhano (Vol I e II)/ Centro de Estudos de Etnologia e Instituto de Investigação Tropical. Museu de Etnologia. Lisboa. 1985
Para além da fotografia, nos últimos anos, alguns etnógrafos alicerçaram suas pesquisas em vultosos grafismos, que de fato borram o limite entre ciência e arte, como o português Fernando Galhano e mais recentemente o australiano Robert Powel. Ana Isabel Afonso chama de "antropologia gráfica" o tipo de investigação etnográfica que tem como alicerce a imagem (AFONSO, 2004, p. 73). O antropólogo norte americano Michael Taussig defende que o desenho no caderno de campo, no âmbito da etnografia, tem uma importância especial no processo investigativo, como "guardião da experiência" e dispositivo de contínua revisão da mesma, para além do texto escrito. Ele se questiona:

Porque desenhar em cadernos? Uma razão, em meu caso pessoal e talvez também em outros, eu suspeito, é o desespero, senão mesmo o terror de escrever, porque quanto mais escrevemos no caderno, mais adquirimos a sensação de que a realidade retratada recua, de que a escrita está empurrando a realidade pra fora da página. Talvez seja uma ilusão. Mas ilusões também são reais (TAUSSIG, 2011, p. 16, tradução nossa).

De alguns anos pra cá, muitos artistas visuais têm vindo a buscar um diálogo intenso com a etnografia, apropriando-se de seus métodos em processos que têm sido denominados "etnografia espontânea", "sensibilidade antropológica" ou antropologia paralela" (ALMEIDA, 2013, p.80). Por sua vez, os antropólogos, acompanhando o crescente nomadismo entre as disciplinas, são desafiados a estabelecerem relações com as obras dos artistas.

No presente trabalho, convidei pessoas a andarem comigo pelo seu bairro. Simplesmente caminhar e conversar, sem ter absolutamente nenhum objetivo final, nem ponto de chegada e pelo tempo que o(a) convidado(a) desejasse. A situação não esteve configurada numa dinâmica de perguntas e respostas e sim de fluxo de ideias, sem previsão. Chamei esta ação de entrevista-passo. Foram escolhidas três pessoas de cinco localidades de São Paulo, baseadas, grosso-modo, na posição destas no mapa da cidade de acordo 
com os pontos cardeais - Brás, Vila Anglo Brasileira, Perus, São Mateus e Cotia. O encontro com cada uma delas, em quase todos os casos, se deu perguntando a amigos se conheciam alguém de tal lugar escolhido (a maioria dos quais eu jamais havia ido antes). As conversas gravadas e as fotos tiradas formam o substrato que se trasformou no livro Cidade Passo.

As imagens produzidas a partir das entrevistas-passo não têm a pretensão de ser um retrato fiel, nem mesmo qualquer espécie de guia sobre os lugares. O livro é um relato de experiência, uma "narrativa errante", na definição de Paola Berenstein Jacques, uma das autoras sobre as quais me debrucei para entender conceitualmente a prática levada a cabo neste projeto. Cidade Passo, tanto do ponto de vista gráfico, quanto conf ceitual é tido como "tecido heterogêneo, dialógico, sinestésico e nada tem a ver com significar, mas com agrimensar, cartografar, mesmo que sejam regiões ainda por vir" (DELEUZE; GUATTARI 1996, p. 13).

No capítulo, Do espaço à imagem, da imagem à experiência, discorro sobre a importância dos mapas subjetivos realizados por criadores de diversas áreas como dispositivos "táticos", capazes de propor conhecimento sobre o espaço para além da visão panóptica e impessoal da cartografia tradicional. Tomo como referência os mapas e livros produzidos por Guy Debord e Asger Jorn no contexto situacionista - La Guide psychogeographique de Paris: discours sur les passions d'amour (1957), Naked City: illustration de l'bypothèse des plaques tournantes (1957), Fin de Copenhage (1957) e Mémoires (1959) - e os livros da artista francesa Sophie Calle, especificamente Les dormeurs (ação de 1979, livro editado em 2000) e Suite Vénitienne (ação de 1980, livro reeditado em 2015).

No capítulo, Cidade Nômade, reflito sobre como ações de deriva e errância e seu posterior "mapa-como-relato" (MARQUEZ, 2009, p. 16), em diversos formatos, permitem

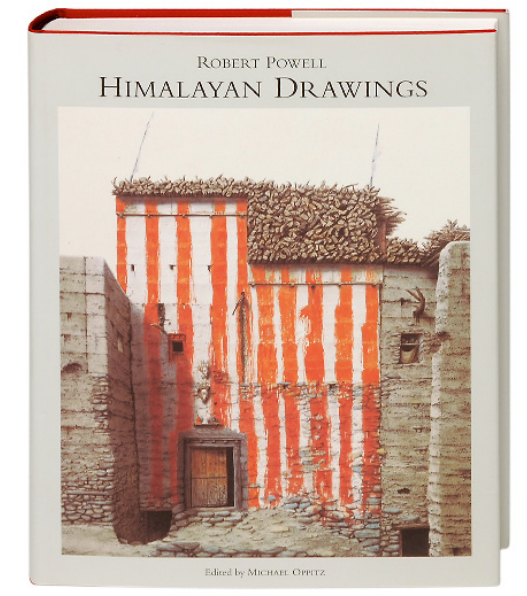

Figura 2 - Himalayan Drawings, Robert Powell/ Ethnographic Museum of the University of Zurich, 2001

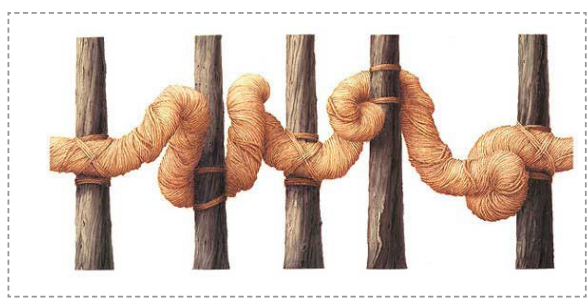

Figura 3- Tlustração interna de Himalayan Drawings

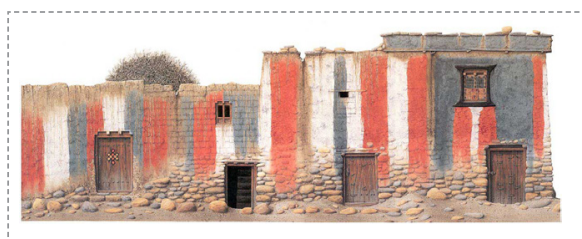

Figura 4 - Ilustração interna de Himalayan Drawings 
arquitetar um espaço-tempo nômade dentro da cidade, capaz de ressignificar as relações que o indivíduo - tanto o próprio artista quanto o público/leitor/usuário - tem com a urbe. Isto ocorre uma vez que os caminhos percorridos, ou seja, o "entre", são tidos como um valor em si, para além dos pontos de chegada, o que cria brechas nos ditames do tempo veloz e funcional, promovendo situações de amabilidade, fruição e reflexão. Trago como exemplos o Guia de terrenos baldios de São Paulo (2006), de Lara Almarcegui e a trilogia I got up, I went e I met (ações feitas entre 1968 e 1979 e livros editados em 2008) do artista conceitual japonês On Kawara.

No capítulo, Devir-artista, devir-etnógrafa, devir-designer, discorro sobre o proceso criativo que deu origem ao livro Cidade Passo, resultado prático desta investigação, que contém as imagens e textos coletados durante as entrevistas-passo, num projeto gráfico que traz à tona, visualmente, os aspectos conceituais que permeiam a pesquisa.

Por fim, em Para um novo começo, aponto alguns sentidos e contribuições que acredito que o trabalho possa trazer aos campos do conhecimento pelos quais perpassa, incluindo a própria arquitetura, como disciplina produtora de sentidos, não apenas de formas.

Nesta investigação, a teoria e a prática são indissociáveis. As relações que busco cartografar fogem a dualismos e tentam estabelecer, impulsionadas pelo desejo, a multiplicidade entre as áreas, como propõe Deleuze:

Por isso é sempre possível desfazer os dualismos de dentro, traçando a linha de fuga que passa entre os dois termos ou os dois conjuntos, o estreito riacho que não pertence nem a um nem a outro, mas os leva, a ambos, em uma evolução paralela, em um devir heterocromo (DELEUZE; PARNET, 1998, p.45). 
2.

do espaço à imagem,

da imagem à experiência 


\section{Quando enfim \\ fechássemos o mapa \\ o mundo se dobraria sobre si mesmo \\ e o meio dia \\ recostado sobre a meia noite \\ iluminaria os lugares \\ mais secretos}

(Ana Martins Marques, “O livro das semelhanças”)

Os mapas tradicionais são associados pelo senso comum a adjetivos como "imparcial", "objetivo", "científico", "neutro" e têm o estatuto de verdade sobre o espaço representado. A projeção cartográfica mais conhecida, a de Mercator, por exemplo, datada do século XVI, apresenta enormes distorções no tamanho das áreas dos continentes (como qualquer outra projeção), porém, por parte do senso comum, é considerada uma imagem verossimilhante do globo terrestre (PENA, 2016).

Ainda que sejam inúmeras as projeções - zenital, gnomónica, estereográfica, ortográfín ca, globular, cônica, cilíndrica, sinusoidal etc - e construídas, configuradas e sustentadas por várias - e bastante arbitrárias - convenções (OBRIST, 2014, p. 6), raramente, em qualquer uma delas, são delineados graficamente os processos 'invisíveis', atributos que atestem a presença humana, traços culturais, sociais, enfim, as relações constitutivas da realidade aparente. É o que Milton Santos chama de "quinta dimensão" do espaço: "a espessura, a profundidade do acontecer”, ou seja, o cotidiano (SANTOS, 1994, p.17). Os mapas pretendem plasmar em uma imagem estática a multiplicidade de processos que ocorrem continuamente, sob a premissa de promover legibilidade, síntese. São representações de um espaço sem tempo, sem duração, instantâneas e totalizadoras. "Simultaneamente instrumento de escritura e de leitura da Terra, os mapas aparecem despovoados na grandeza de sua escala que só comporta a ausência dos corpos" (MARQUEZ, 2009, p.77).

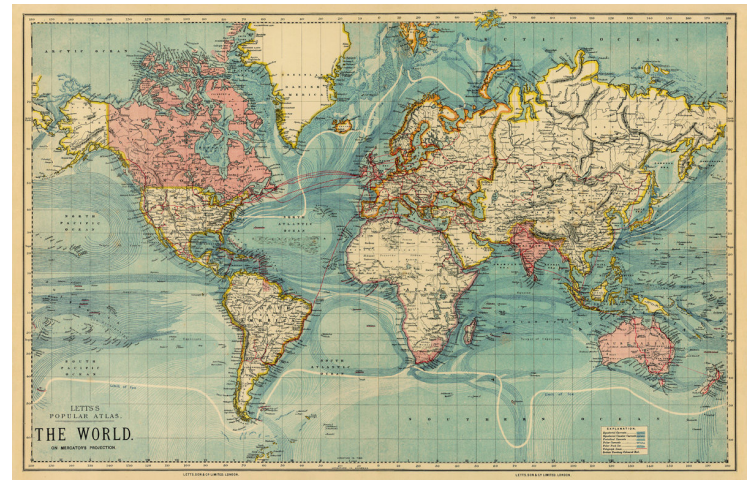

Figura 5 - Projeção de Mercator

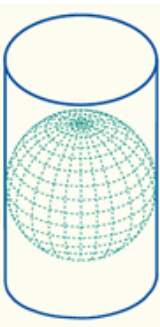

Cylindrical

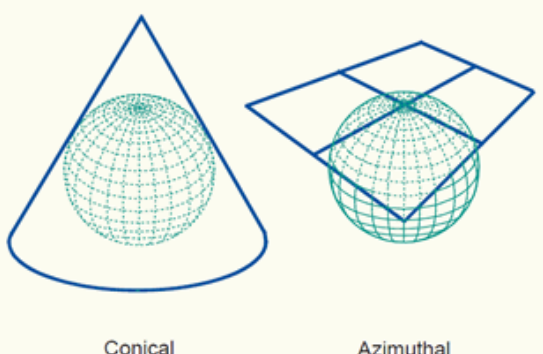

Azimuthal

Figura 6 - Exemplos de projeções cartográficas 


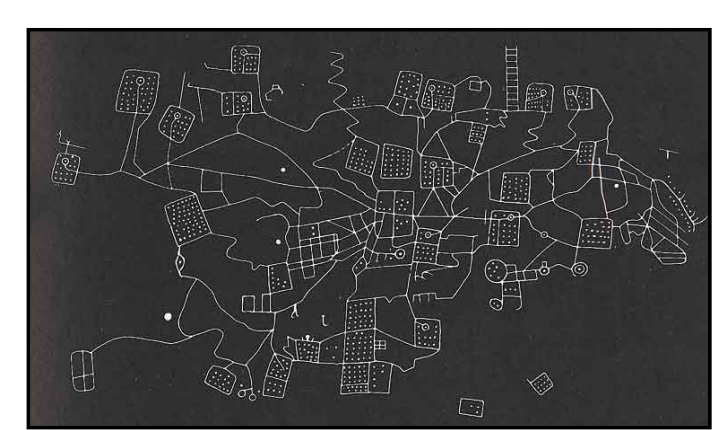

Figura 7 - Gravura rupestre, Bedolina, Val Camonica, cerca de 10.000 a.C

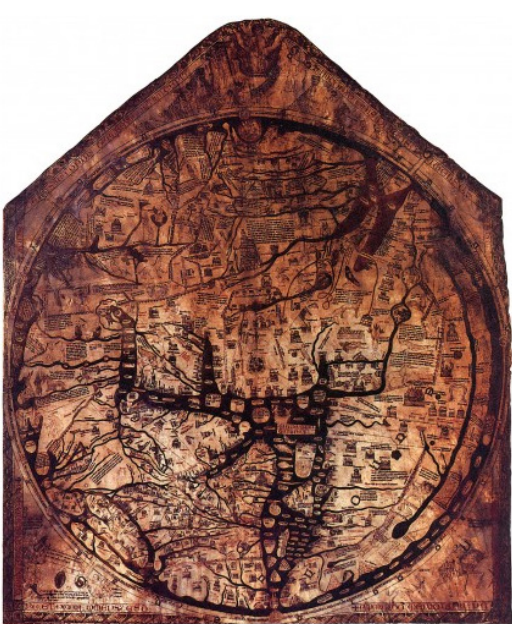

Figura 8 - The Hereford Map (1290 DC, aproximadamente)

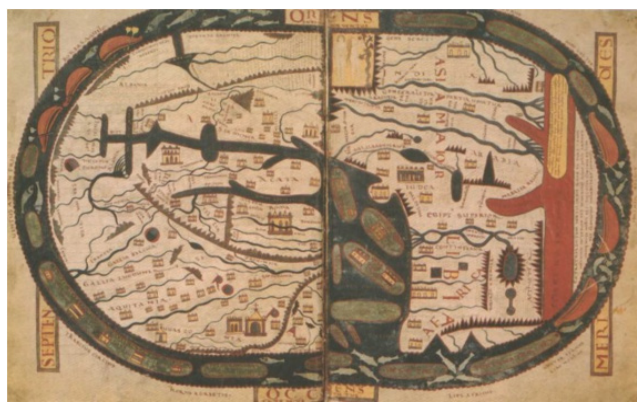

Figura 9 - The Mappa Mundi of Saint Beatus of Liébana (776 DC, aproximadamente)
Um dos primeiros mapas de que se tem registro é datado de aproximadamente 10.000 a.C., gravado em uma rocha localizada entre 400 e 1.000 metros de altitude em Val Camonica, Itália. Trata-se de uma imagem que representa o sistema de conexões da vida cotidiana em um vilarejo paleolítico. O mapa se constitui de linhas no vazio que distribuem ícones e elementos no espaço - figuras humanas, campos de cultivo, área para o gado (CARERI, 2013, p. 47).

Observa-se portanto que a necessidade de apreensão total do espaço vem desde os primórdios das sociedades humanas e seguiu ao longo da história gerando iconografias e grafismos de riqueza narrativa impressionante como no caso dos mapas medievais. A ânsia por ver o todo acompanha o desejo por controlá-lo. As tecnologias de representação sempre buscaram aprimorar a visão panóptica, de “cima”, análoga à visão celeste, dos deuses.

Hoje, esta perspectiva corresponde à do urbanista, ou do cartógrafo, aquele que não está inserido no âmbito do que analisa, projeta ou desenha, apenas observa, isolado, tendo portanto o que Michel de Certeau chama de "visão estratégica". Busca prever. Nas palavras do autor: “Chamo de 'estratégia' o cálculo das relações de forças que se torna possível a partir do momento em que um sujeito de querer e poder é isolável de um 'ambiente"' (CERTEAU, 2014, p.45). Estamos habituados a ler mapas quase sempre numa perspectiva estratégica, de cima, "oniscientes".

Segundo Certeau, oposta à estratégica, temos a visão tática, frontal. Esta seria a dos "praticantes ordinários da cidade". Os que estão "dentro" do mapa mas não são nele representados. São os "homens lentos”, na expressão de Milton Santos (SANTOS, 1993): os caminhantes, os pedestres, "cujo corpo obedece aos cheios e vazios de um texto urbano que escrevem sem poder lê-lo. Esses praticantes jogam com espaços que não se vêem; têm dele um conhecimento tão cego quanto no corpo a corpo amoroso"(CERTEAU, 2014, p. 159). O autor acrescenta ainda: "A tática só tem por lugar, o outro. Ela ai se 
insinua, fragmentariamente, sem apreendê-lo por inteiro, sem poder retê-lo à distância. Ela não dispõe de base onde capitalizar os seus proveitos, preparar suas expansões e assegurar uma independência em face às circunstâncias" (CERTEAU, 2014, p. 45-46).

Ao longo do século XX, muitos artistas ao redor do mundo utilizaram o caminhar como dispositivo de ação e reflexão sobre as relações sociais e sobre o espaço da cidade. A partir de sua experiência, foram geradas cartografias "táticas", de dentro, subjetivas, nos suportes e formatos dos mais diversos como fotografias, desenhos, instalações, vídeos, livros, pôsteres etc. Renata Marquez chama de "mapas performativos", ou "mapas-como-relato" essas construções visuais que, ao contrário da fixidez do olhar vertical que mede o território de fora dele como na cartografia tradicional, instauram um "novo olho móvel", que não encontra conforto, permanece numa condição sempre vagueante (MARQUEZ, 2009, p. 16).

O início das práticas de mapas subjetivos no século XX remontam o final dos anos 50, pós Segunda Grande Guerra. Neste período, ao passo que a influência dadaísta e surrealista - sintetizada sobretudo na poética ready made de Marcel Duchamp - se desdobra nos Estados Unidos em uma arte "objetual" como a pop art e o minimalismo, na Europa, essas escolas disparam reflexões que levaram a ações no âmbito do urbano (MADERUELO, 2008, p. 163). Crescia em importância a discussão sobre a crescente alienação dos espaços públicos como lugar de convivência, na medida em que o automóvel começava a ganhar cada vez mais importância nas escolhas urbanísticas das cidades. Essa ambiência suscita questionamentos por partes de artistas e intelectuais, que se inclinam a ver a cidade para além de seus aspectos puramente morfológicos e econômicos, mas como cenário específico de relações humanas, de intercâmbio de ideias, de cotidianidades particulares, sendo portanto um rico manancial de interesses existenciais e estéticos.

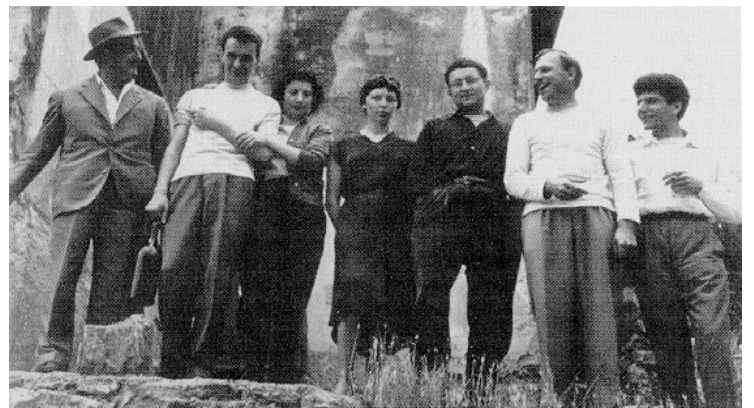

Figura 10 - Fundadores da Internacional Situacionista em Cosio d'Arroscia, Itália, abril de 1957. Da esquerda para a direita: Guiseppe Pinot Gallizio, Piero Simondo, Elena Verrone, Michele Bernstein, Guy Debord, Asger Jorn, e Walter Olmo. 
É nesse contexto que criadores reunidos na Internacional Situacionista ${ }^{2}$, em Paris, especialmente o escritor Guy Debord, propuseram o caminhar como método "passional objetivo" de exploração da cidade (CARERI, 2013, p. 85). O intuito era opor-se ao funcionalismo moderno, racional, que priorizava o fluxo de carros e construções de grande escala em detrimento do espaço relacional, lento, humano, do pedestre. Os situacionistas elaboraram o que se chamou de "teoria da deriva", que tomava o "perderse" como um valor analítico, crítico e poético. A deriva seria a apropriação do espaço urbano pelo pedestre através da ação do andar sem rumo, obedecendo a uma geografia afetiva, pessoal, que Debord chamou de "psicogeografia". Em suas palavras:

A geografia, por exemplo, explica a ação determinante de forças naturais gerais, como a composição dos solos ou os regimes climáticos, sobre as formações econômicas da sociedade e, por isso, sobre o conceito de mundo que esta pode ter. A psicogeografia seria o estudo das leis exatas e dos efeitos precisos do meio geográfico, planejado conscientemente ou não, que ajem diretamente sobre o comportamento afetivo dos indivíduos. $\mathrm{O}$ adjetivo psicogeográfico, que guarda uma imprecisão interessante, pode portanto ser aplicado aos dados estabelecidos por esse gênero de pesquisa, aos resultados de sua influência sobre os sentimentos humanos e até, de modo mais geral, a qualquer situação ou conduta que pareçam provir do mesmo espírito de descoberta (DEBORD apud JACQUES, 2003, p. 39).

Os situacionistas propunham o uso do tempo e do espaço da cidade de forma não utilitária, e essa prática era estruturante em seu projeto de "preparar uma revolução fundada no desejo" (CARERI, 2013, p. 98). Estar perdido torna-se, portanto, um valor, porque é quando se deixa de exercer controle e domínio, e se é dominado pelo próprio espaço. Perder-se pode ser praticado, portanto, como forma de adquirir novos estados de consciência.

${ }^{2}$ A Internacional Situacionista (IS) foi um grupo de artistas, pensadores e ativistas reunidos nos anos 50, de diversos países da Europa, que lutava contra a não-participação, a alienação e a passividade da sociedade decorrente do sistema capitalista. O interesse dos Situacionistas pelas questões urbanas foi uma consequência da importância dada por estes ao meio urbano como terreno de ação, de produção de novas formas de intervenção e de luta contra a monotonia ou ausência de paixão da vida cotidiana moderna. 
A criação de mapas esteve diretamente associada às práticas de deriva. As caminhadas eram registradas de diversas maneiras - textos, desenhos, fotografias, filmagens etc - e a partir deste material eram feitas composições que pouco ou nada tinham da cartografia tradicional, mas que pretendiam trazer representações de trajetos possíveis dentro da cidade. Para além do registro das experiências pessoais vividas no espaço urbano, imagens conceituais foram criadas. Destaco aqui: Guide psychogeographique de Paris: discours sur les passions de l'amour ${ }^{3}$ (1957), Naked City: illustration de l'hypothèse des plaques tournantes ${ }^{4}$ (1957) e os livros Fin de Copenhague ${ }^{5}$ (1957) e Mémoires ${ }^{6}$ (1959).

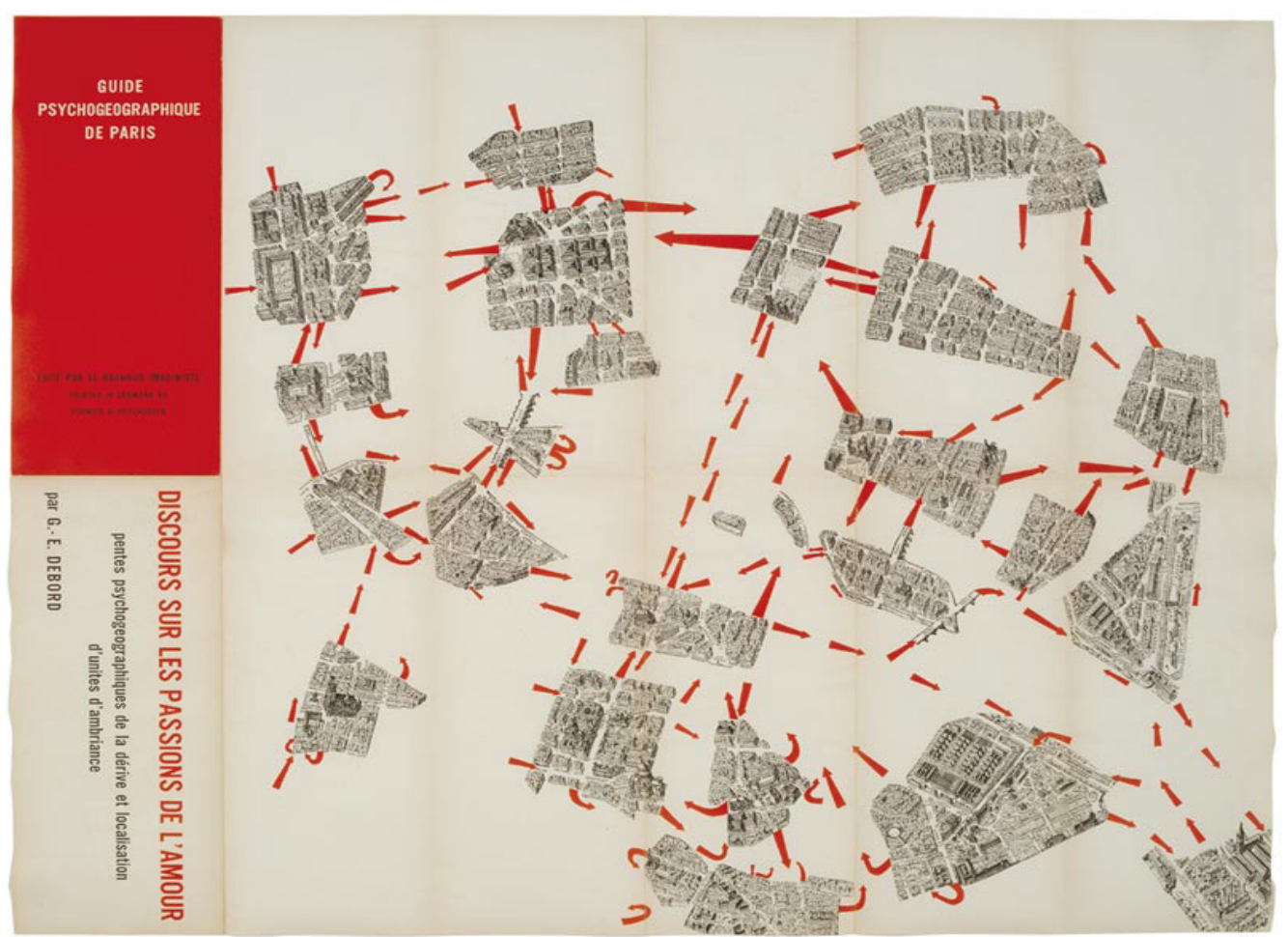

Figura 11 - Guide psychogeographique de Paris : discours sur les passions de l'amour (1957), Guy Debord

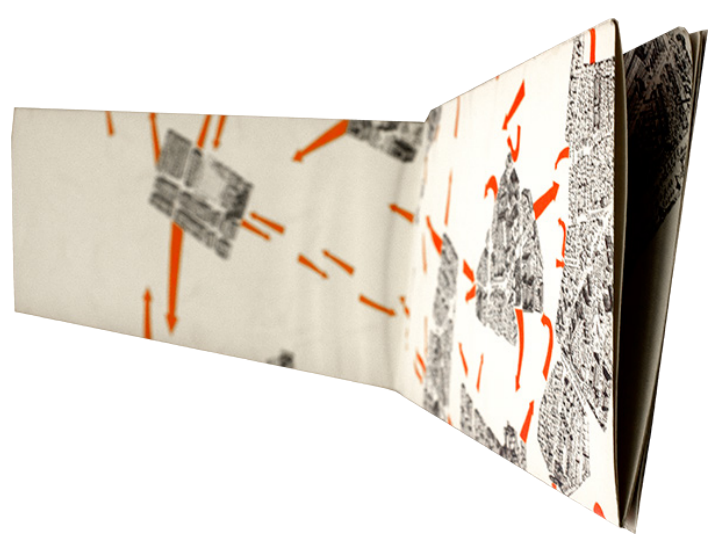

Figura 12 - Guide psychogeographique de Paris/ dobra

${ }^{3}$ Guia psicogeográfico de Paris: discurso sobre as paixões do amor (tradução nossa)

${ }^{4}$ Cidade nua: ilustração da hipótese das placas giratórias (tradução nossa)

5 Adeus, Copenhague (tradução nossa)

${ }^{6}$ Memórias (tradução nossa) 

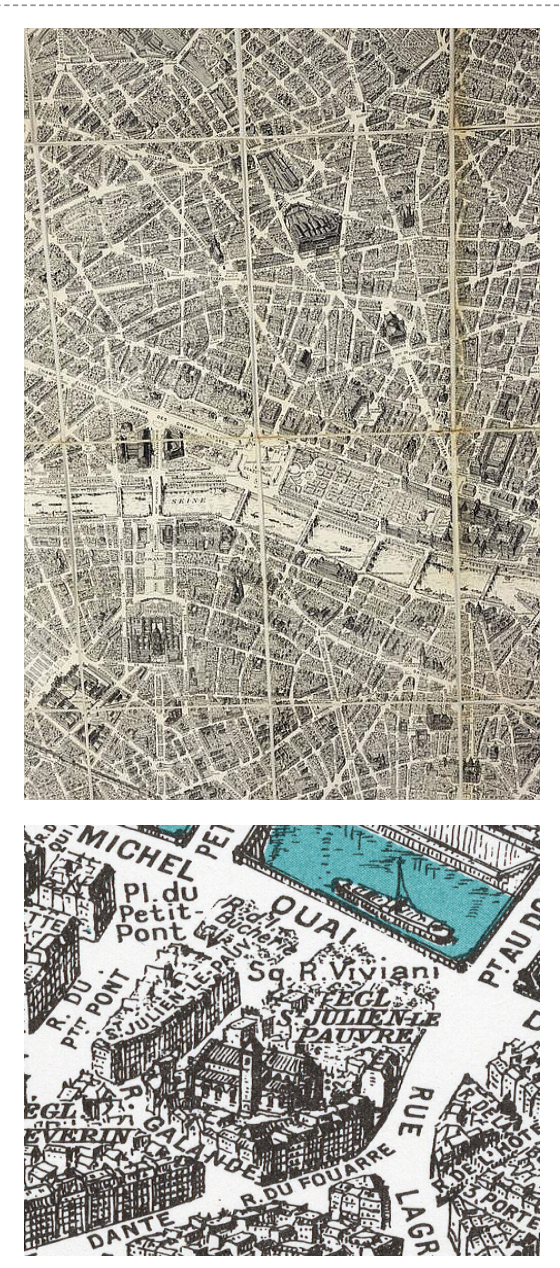

Figura 13 - Detalhes de Plan de Paris à vol d'oisean, Georges Peltier
Guide psychogeographique de Paris : discours sur les passions de l'amour, de Guy Debord, foi o primeiro mapa psicogeográfico pensado de fato para uso de um público.

Está concebido para ser um mapa dobrável para ser distribuído aos turistas; mas é um mapa que convida a perder-se. (...) Ao abrirmos esse estranho guia, encontramos Paris explodida em pedaços, uma cidade cuja unidade foi completamente perdida e na qual reconhecemos apenas fragmentos da cidade histórica que flutuam num espaço vazio. O hipotético turista deve seguir as setas que unem unidades de ambiente, zonas homogêneas determinadas com base em relevos psicogeográficos (CARERI, 2013, p. 92).

Para produzir o seu Guide Psychogeographique, Debord utilizou o mapa Plan de Paris à vol d'oiseau desenhado por Georges Peltier, que representa uma vista aérea de Paris extremamente detalhada, feita à mão. Este mapa é um plano clássico da capital francesa e sua feitura durou 20 anos, tendo sido iniciada em 1920 e finalizada em 1940.

A operação de Debord no mapa de Peltier corresponde a um movimento de desestruturação de uma imagem contínua, totalizante da cidade e sugere ao observador uma desorientação, ao separar as regiões em pequenas ilhas ou "unidades de ambiência", conectadas arbitrariamente, subvertendo a noção de proximidade, distância, fronteiras. O objetivo de Debord era distribuir esse guia aos pedestres para que eles pudessem se perder na cidade, e que o mapa fosse refeito com novas derivas.

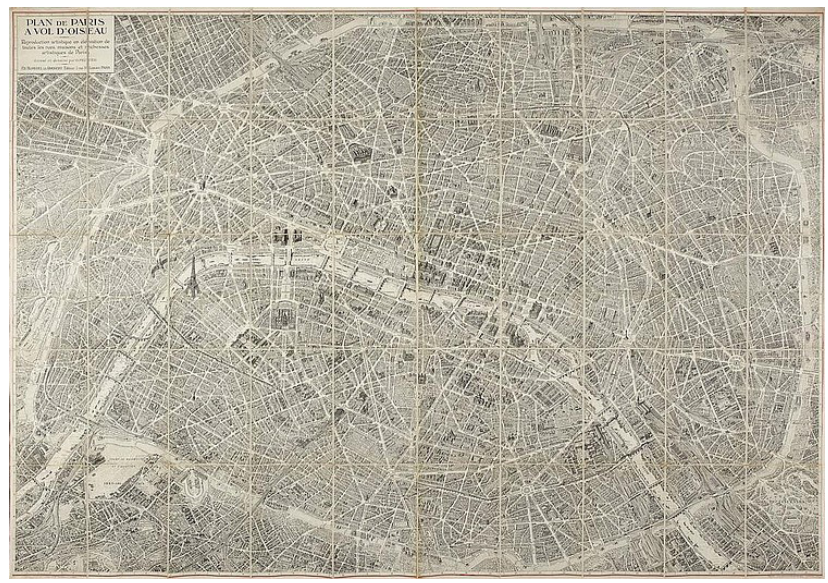

Figura 14 - Plan de Paris à vol d'oisean, Georges Peltier 


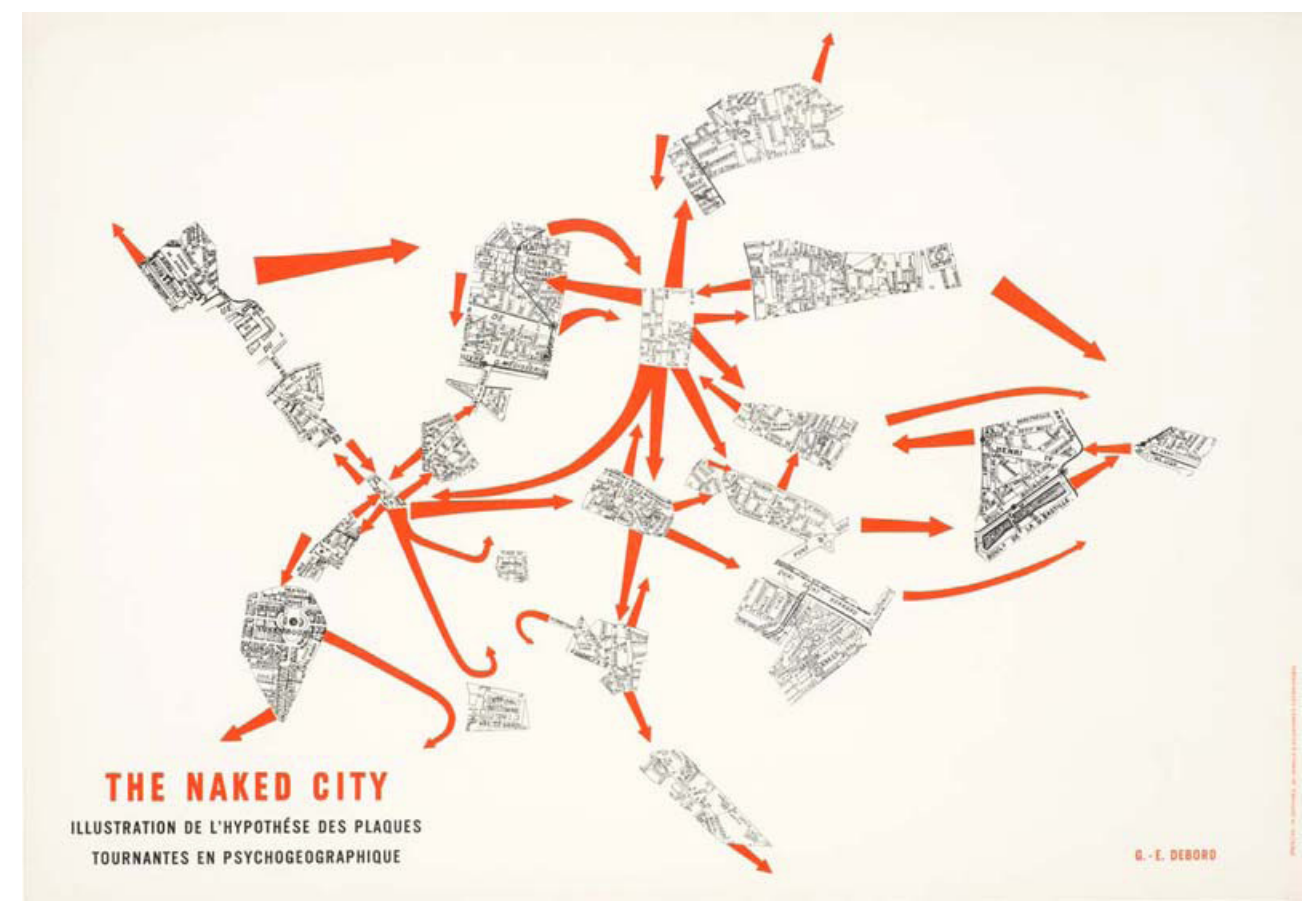

Figura 15 - Naked City: illustration de l'hypothèse des plaques tournantes (1957), Guy Debord

Já Naked City: illustration de l'hypothèse des plaques tournantes, também de 1957, outro mapa realizado por Debord partindo do mesmo princípio de fragmentação, está composto por dezenove partes de um plano oficial da área central que está no Guide Taride de Paris.

Flechas em vermelho com densidades variadas indicam as direções espontâneas dos segmentos psicogeográficos, com suas forças de atração e repulsão entre as placas urbanas sinalizando graus de intensidade e comprimento dos relacionamentos surgidos durante a deriva entre essas áreas. Caminhar usando esses mapas significa navegar sobre os vazios de uma paisagem psíquica para encontrar as nossas próprias conexões, refazendo a nossa orientação sobre a cidade e seu planejamento (MESQUITA, 2003, p. 20).

O título "Naked City" faz referência ao filme noir homônimo de Jules Dassin, filmado em 1948, cuja cidade (Nova York) em si mesma é o personagem principal. A narração na película se conclui com a fala icônica: "Existem oito milhões de histórias na cidade nua. Esta foi uma delas".

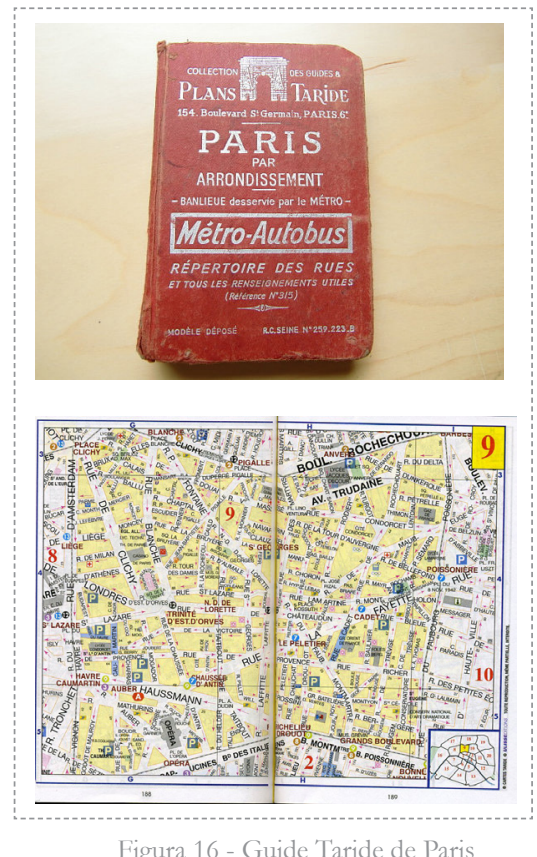

Figura 16 - Guide Taride de Paris 


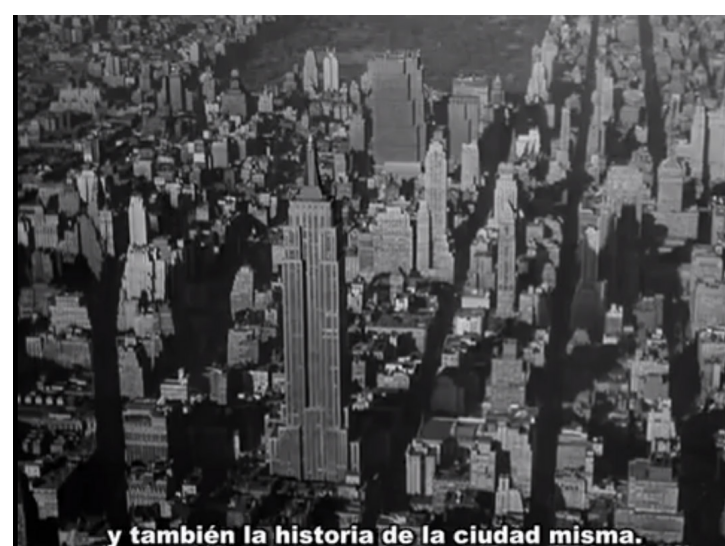

Figura 17 - Frame do filme Naked City (1948), de Jules Dassin

A pergunta subjacente aos mapas citados não é “aonde?” esses dispositivos cartográficos podem nos levar, mas "a que estado?”. Os usos implícitos ali estão para além da racionalidade, exigem que outros sentidos sejam ativados.

O que ocorre quando o mapa deixa de pretender apresentar uma visão onisciente, neutra, e se transforma em relato de experiência, para além da sua função instrumental de ser legível? Sua propriedade comunicacional desdobra-se de leitura técnica, que visa transmitir conhecimento "consolidado" para uma proposição aberta, construtiva, uma prática espacial. Renata Moreira Marquez chama esse tipo de procedimento de "extravio cartográfico", uma vez que nele, o mapas podem ser "reinstrumentalizados como manual, dispositivo de relato novo, guia para navegações cotidianas que vão além do seu lugar-matriz (MARQUEZ, 2009, p.84).

Através dessas cartografias subjetivas, as potências dos espaços construídos, fixos, são atualizadas e transformadas em relação viva, real, fluida. Sobre esse fazer cartográfico, a autora continua:

A sua mobilidade desafia a formação de um conhecimento estável e estático e propõe a construção de redes de conhecimento fundamentado em suas relações subjetivas. Nota-se um esforço de habitar o mapa, de invadir as suas linhas geometrizadas com o ímpeto do corpo, com as suas histórias de reconhecimento dos espaços, com a sua capacidade performativa cotidiana (ibid., p. 16).

Para além de um aparato técnico geográfico, Deleuze e Guattari propõem o mapa como um conceito filosófico, a imagem de um fenômeno em curso e não uma representação final. O mapa é mais o "processo que a imagem formal, é o próprio movimento, o germinar, o crescimento, o ímpeto" (JACQUES, 2003, p. 108). Nas palavras dos autores:

Se o mapa se opõe ao decalque é por estar inteiramente voltado para uma experiência ancorada no real. O mapa não reproduz um inconsciente fechado sobre ele mesmo, 
ele o constrói. Ele contribui para a conexão dos campos, para o desbloqueio dos corpos sem órgãos, para sua abertura máxima sobre um plano de consciência. Ele faz parte do rizoma. O mapa é aberto, é conectável em todas as suas dimensões, desmontável, reversível, sucetível de receber modificaçoes constantemente. Ele pode ser rasgado, revertido, adaptar-se a montagens de qualquer natureza, ser preparado por um indivíduo, um grupo, uma formação social. Pode-se desenhá-lo numa parede, concebê-lo como obra de arte, construí-lo como uma ação política ou como uma meditação (DELEUZE; GUATTARI, 1995, p.22 ).

Fin de Copenhague é um livro editado em 1957, primeira colaboração entre Guy Debord e Asger Jorn, também membro da Internacional Situacionista. A autoria é creditada a Asger Jorn e tem Debord listado como “Conselheiro técnico em 'détournement”" (devio).

Composto por camadas de cores vibrantes, a publicação traz textos pontuais em inglês, francês, alemão e dinamarquês, bem como ilustrações de garrafas de whisky, cerveja, cigarros, aviões, barcos, desenhos de mulheres bem vestidas e muitos mapas de Copenhague. Cada página está coberta com uma segunda camada de gotas e manchas de tinta. O livro termina com o texto: “Corra! Corra! Corra! Conte-nos em não mais que 250 palavras porque sua garota é a mais doce na cidade."

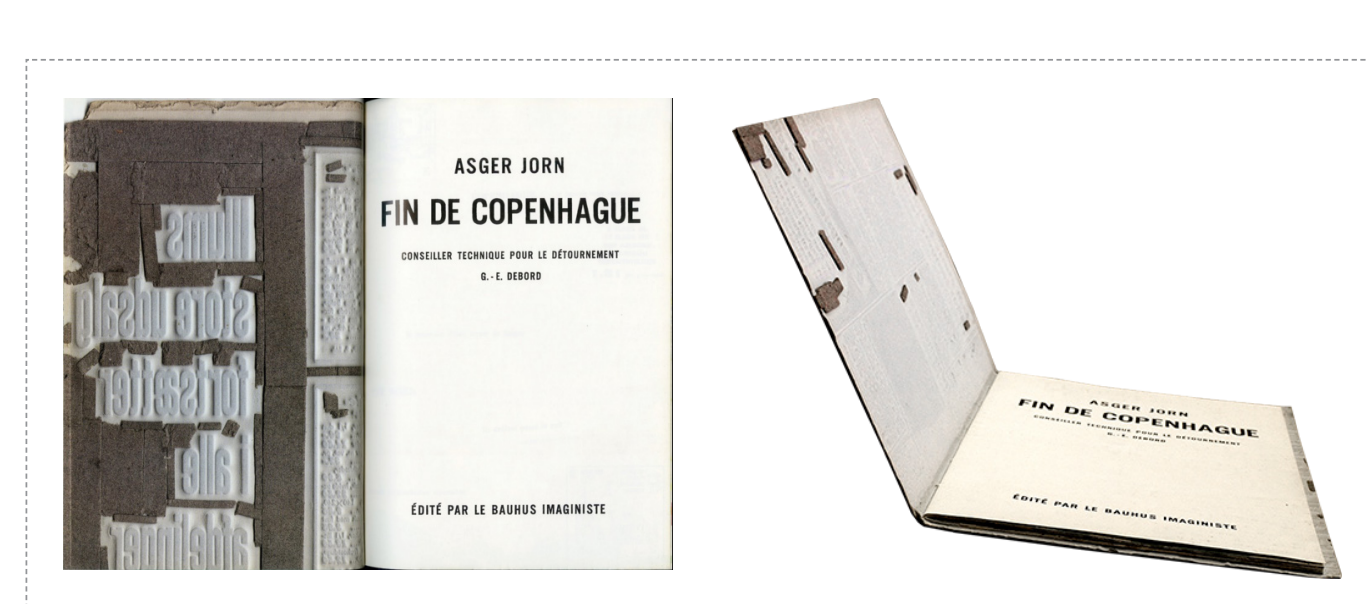

Figura 18 - Fin de Copenhague (1957), Guy Debord e Asger Jorn
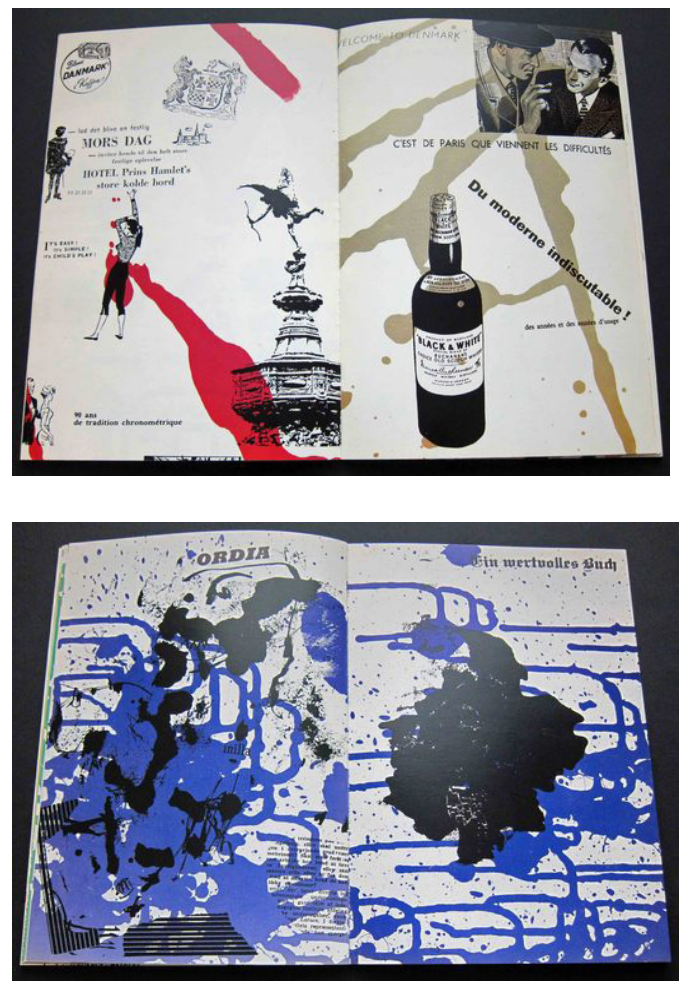

Figura 19 - Páginas de Fin de Copenbague 


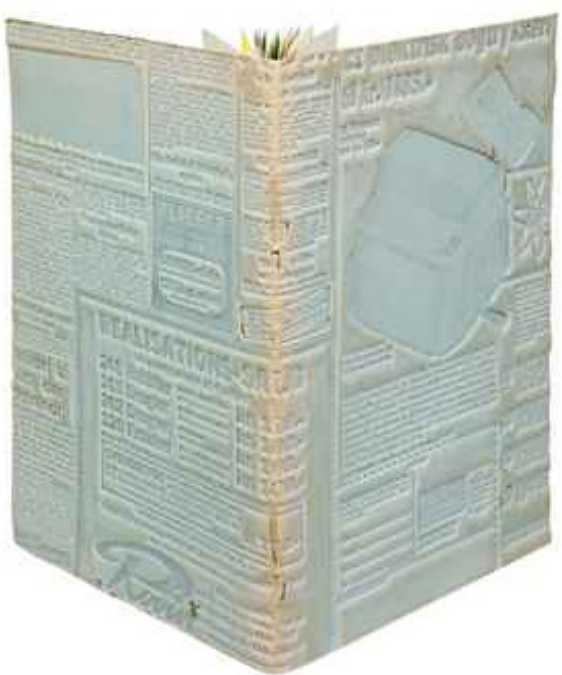

Figura 20 - Capa de Fin de Copenhague
Ao chegar em Copenhague, Jorn e Debord roubaram uma enorme quantidade de revistas e jornais e passaram a tarde a beber e produzir colagens. No seguinte dia eles chegaram aos impressores com 32 colagens, que transferiram para placas litográficas. Então, Jorn sentou em cima de uma escada sobre as placas de zinco, derramando um copo de tinta indiana após o outro sobre elas. As placas foram gravadas e impressas sobre os textos e imagens em preto. A capa era uma imagem em altíssimo relevo de um anúncio de lâmina de barbear. Originalmente impresso em 1957, em uma edição de 200 exemplares pela Bauhaus Imaginiste, Fin de Copenhague foi reimpresso pelas Editions Allia, em 2001 (NOLLE, 2016).

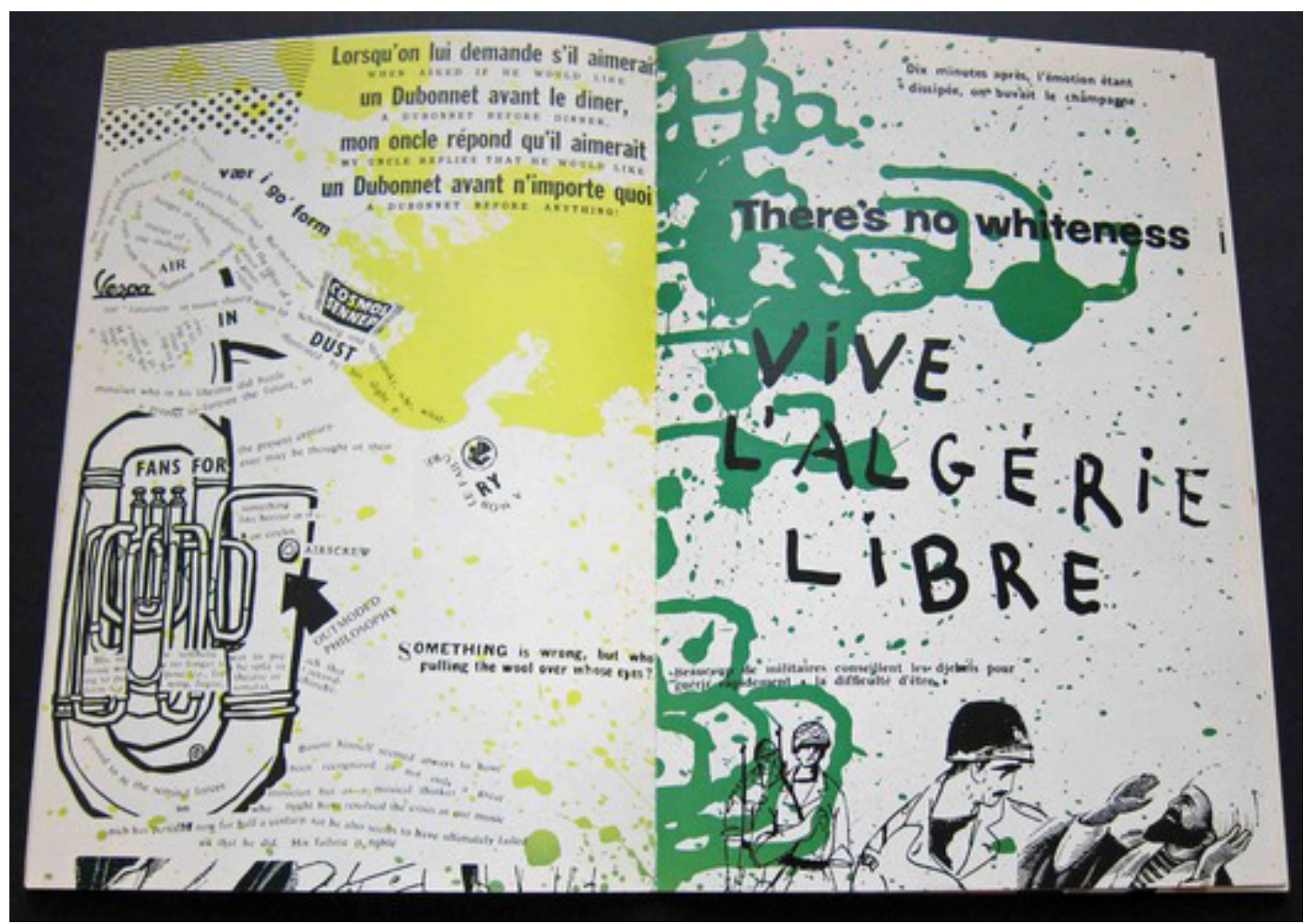

Figura 21 - Fin de Copenhague (1957), Guy Debord e Asger Jorn 


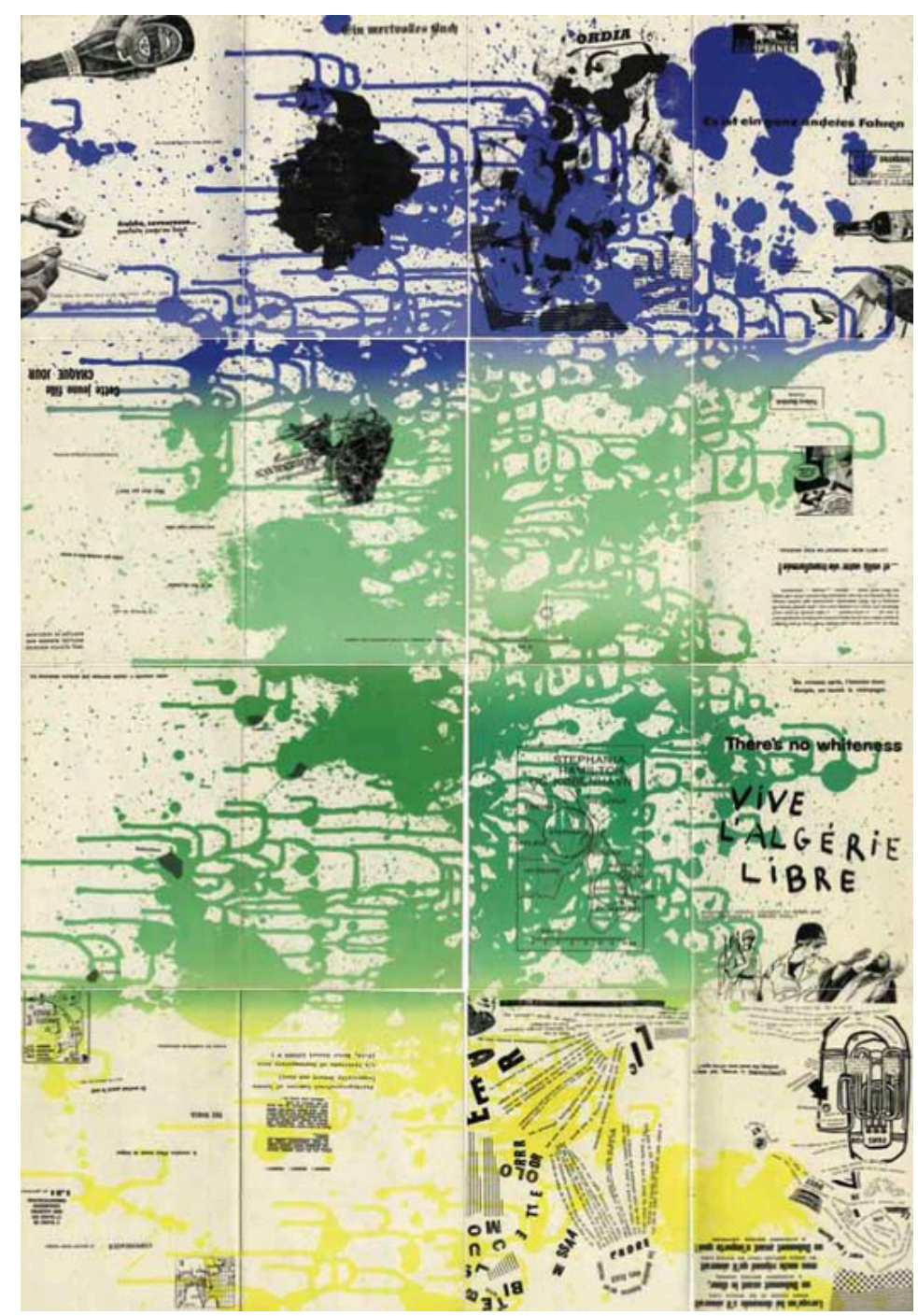

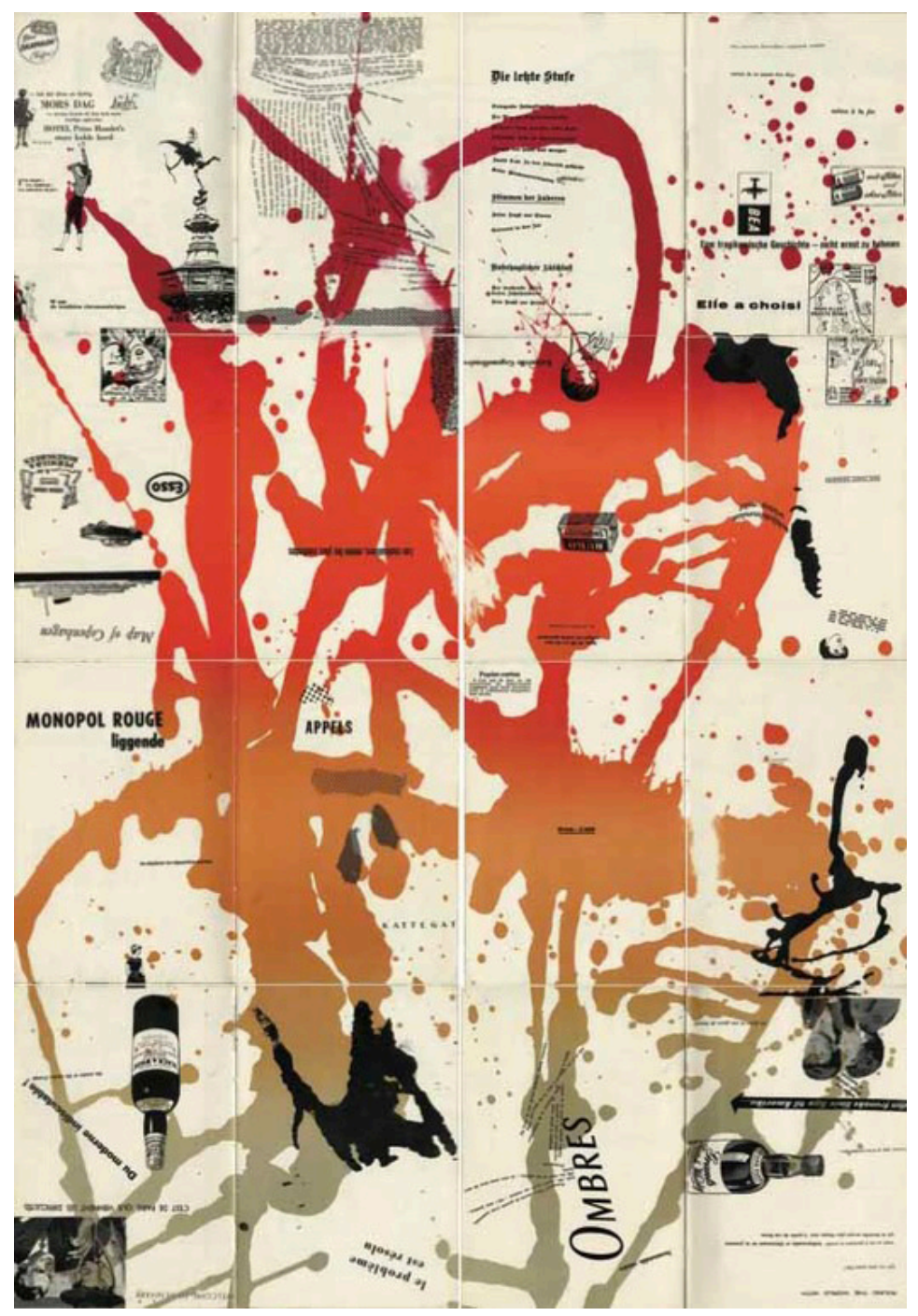

fig 22 - Impressões das placas de Fin de Copenhague antes da montagem 


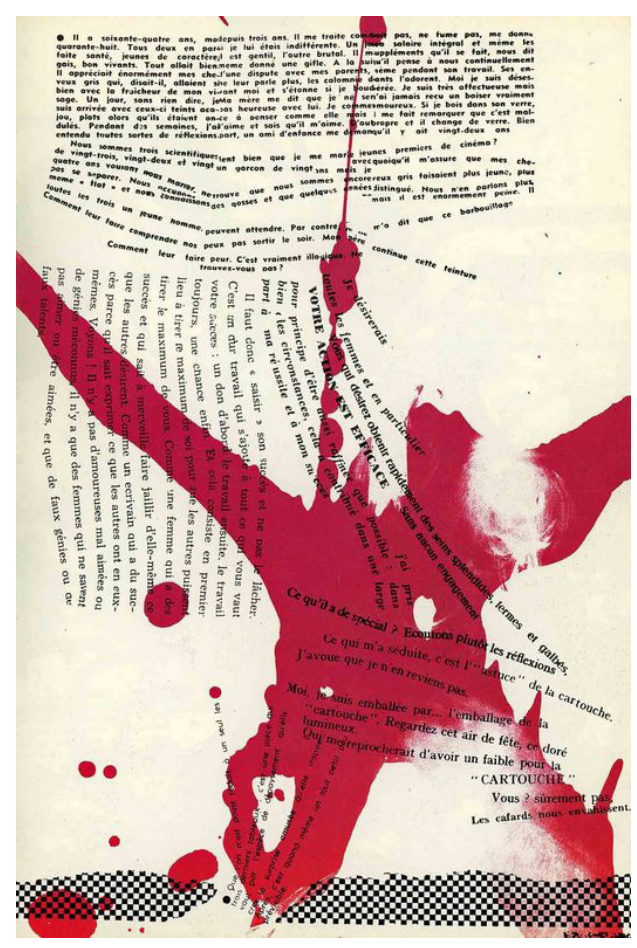

Figura 23-Mémoires (1959), Guy Debord e Asger Jorn

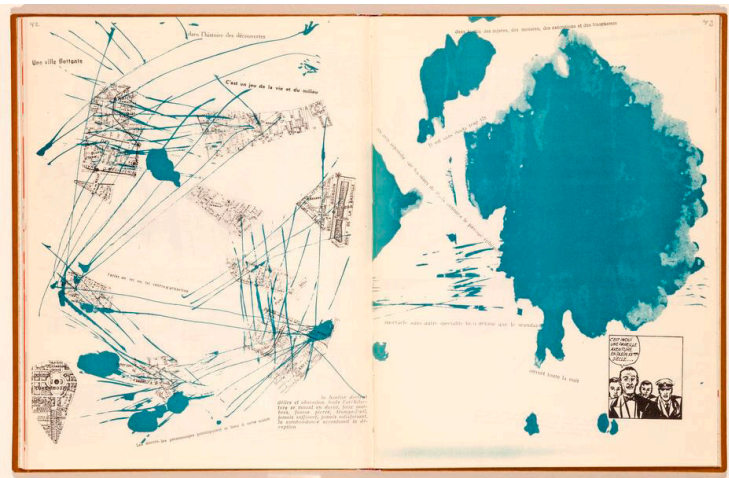

Figura 24 - Mémoires (1959), Guy Debord e Asger Jorn

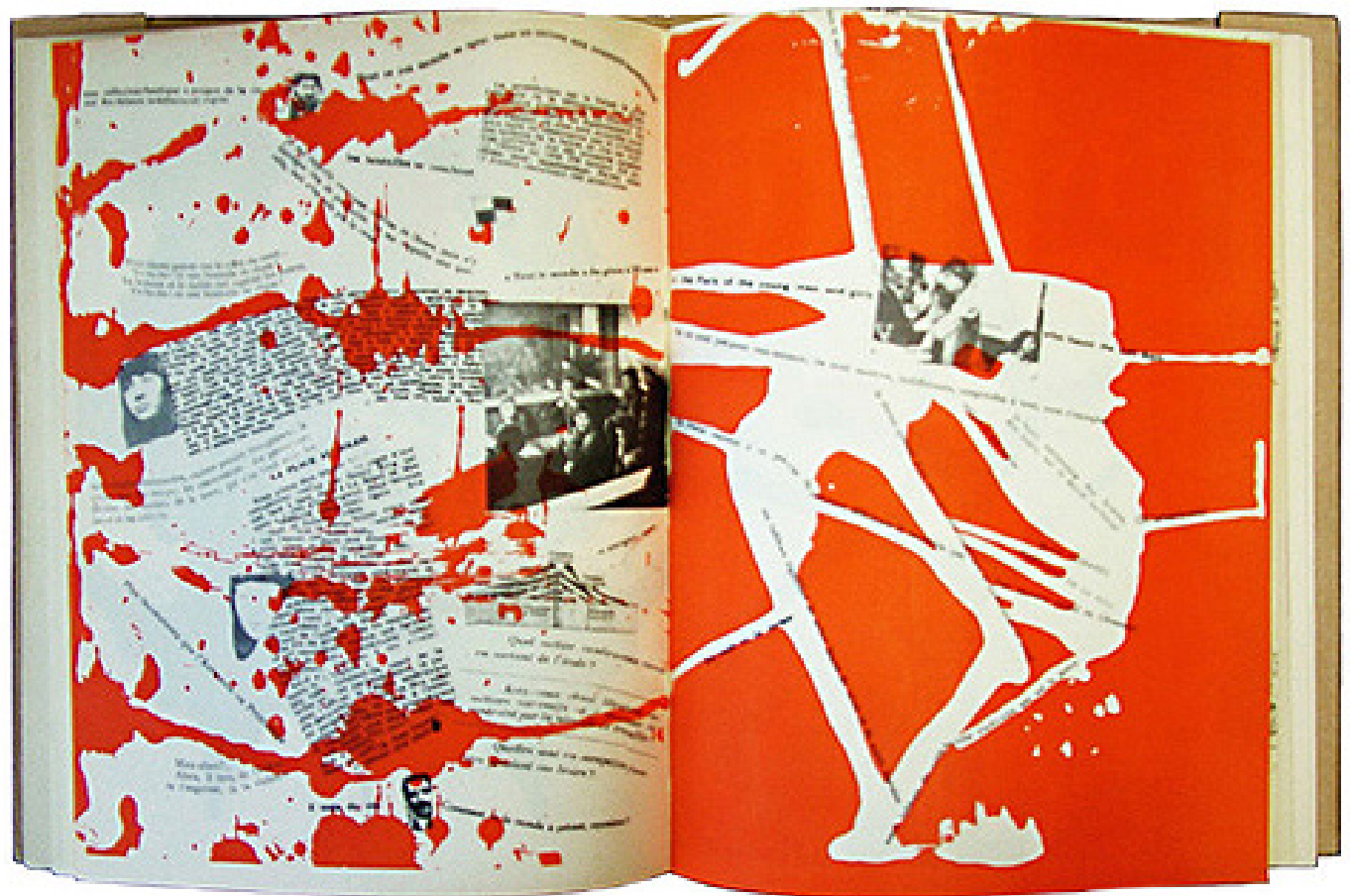

Figura 25 - Mémoires (1959), Guy Debord e Asger Jorn

O livro de artista Mémoires é a segunda colaboração entre Debord e Jorn, impresso em 1959. O trabalho contém duas camadas separadas. A primeira é impressa em tinta preta, reproduzindo textos e gráficos encontrados em revistas e jornais. A segunda utiliza tintas coloridas, jogadas entre as páginas, às vezes conectando imagens e textos, outras cobrindo-os e por vezes ainda desconectados da composição. A camada em preto contém fragmentos de textos, mapas de Paris e Londres, reproduções de obras clássicas e perguntas como "Como você se sente no momento, Senhor?". Outras páginas têm mais a ver com temas mais específicos, como referências à deriva, com textos e colagens justapostas caoticamente e sem preocupação estrita com a legibilidade. A última página é uma mancha laranja, sobre o qual se lê a seguinte sentença: "Eu gostaria de falar a bela língua do meu século" (ibid., 2016). 
A capa foi feita com uma lixa de grau pesado. Sobre a intenção e efeito deste material, o editor ironiza: "Você pode imaginar o resultado quando o livro é pousado sobre uma mesa polida de mahogany, ou quando é inserido ou tirado de uma estante de livros" (ibid., 2016).

Mémoires também foi impresso em Copenhague, pela Éditions Situationist International. Em 1999, foi reimpresso por Jean-Jacques Pauvert aux Belles Lettres.

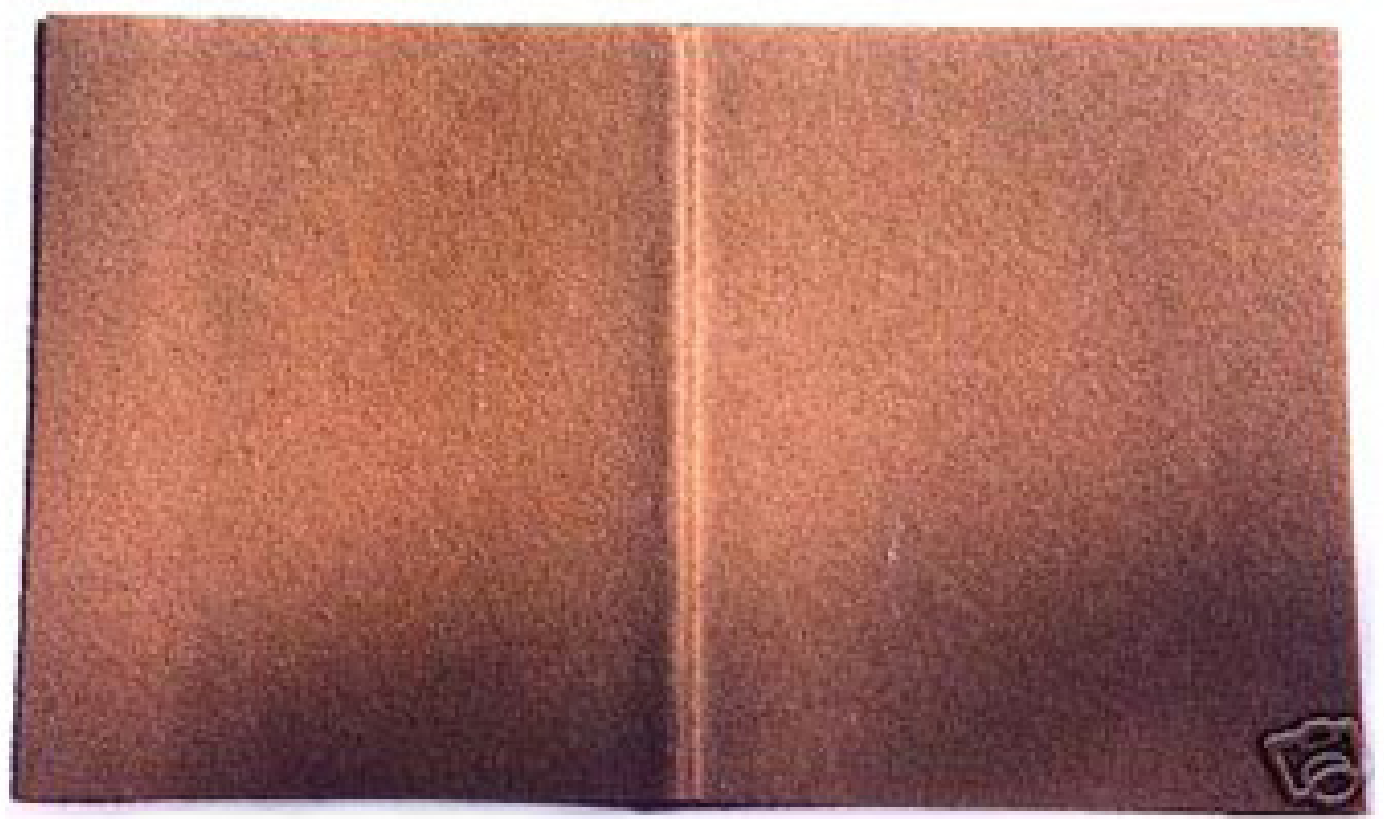

Figura 26 - Capa de Mémoires (1959), Guy Debord e Asger Jorn

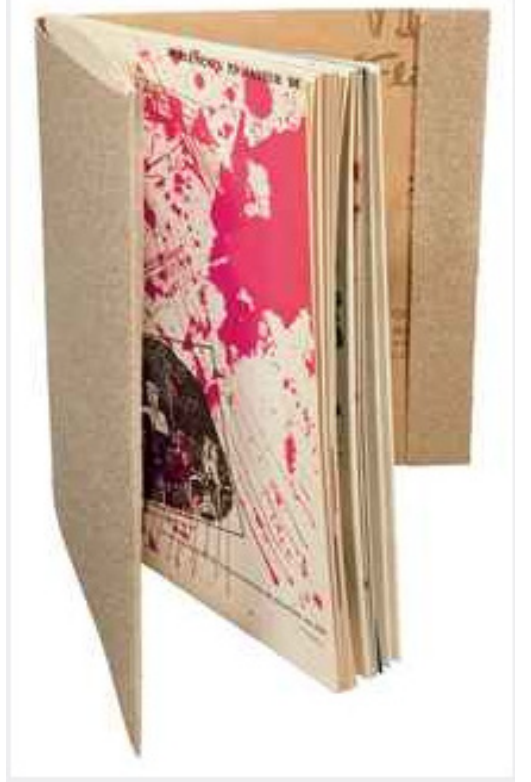

Figura 27 - Mémoires (1959), Guy Debord e Asger Jorn

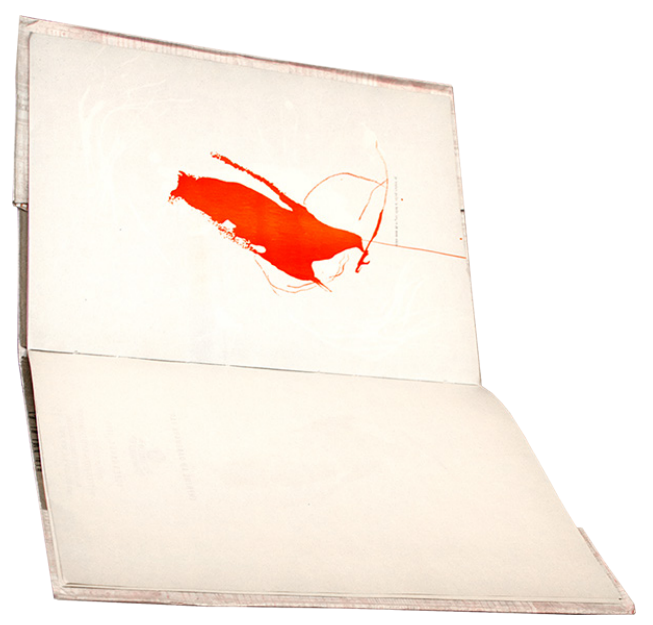

Figura 28 - Última página de Mémoires (1959), Guy Debord e Asger Jorn 
Nos quatro trabalhos gráficos Situacionistas citados, a imprevisibilidade da forma final é fundamental no processo criativo. Tanto nas colagens como nas aplicações aleatórias de camadas de tinta, existe a presença central do acaso, dos acidentes de percurso, não existe um "projeto" estritamente definido e sim uma intenção conceitual. O erro é elemento chave nesses trabalhos e leva, tanto o criador quanto o espectador a inventar “sentidos aventureiros", não calculados, na expressão de Rosane Preciosa. Tomando as palavras desta autora, podemos dizer que o criador Situacionista é:

Um laboratório pulsante que não se isola do mundo para melhor senti-lo. Ao contrário, monta sua "pesquisa de sensações" à beira de seus próprios abismos. Algo decerto perturbador, mas liberador também, porque dai surgem formas imprevistas, que forçam sujeito e linguagem a se desacomodar, e inventar sentidos aventureiros, que ultrapassam o registro da mera comunicação de algo (PRECIOSA, 2010, p. 16).

A “construção de situações" era, para os situacionistas, uma ferramenta política para a transformação concreta da vida das pessoas, ou em suas palavras "a construção concreta de ambientes momentâneos da vida e sua transformação em uma qualidade passional superior" (DEBORD, 1957).

A partir da noção de psicogeografia, segundo a qual o ambiente em que vive um indivíduo atua diretamente sobre seu comportamento afetivo, o desejo do grupo era desenvolver um urbanismo unitário como programa para a transformação integral da vida, tendo a construção de situações como ferramenta conscientemente subordinada a este programa:

A vida de um homem é um cúmulo de situações fortuitas, e se nenhuma delas é similar a outra, ao menos estas situações são, na imensa maioria, tão indiferenciadas e sem brilho que dão perfeitamente a impressão de similitude. O corolário deste estado de coisas é que as escassas situações destacáveis conhecidas em uma vida, retêm e limitam rigorosamente esta vida. Temos que tentar construir situações, isto é, ambientes coletivos, um conjunto de impressões que determinam a qualidade de um momento. Se tomamos o exemplo simples de uma reunião de um grupo de indivíduos durante um tempo dado, terá que estudar, tendo em 
conta os conhecimentos e os meios materiais de que dispomos, a organização do lugar, a eleição dos participantes e a provocação dos acontecimentos que convém ao ambiente desejado (DEBORD, 1957).

A artista francesa Sophie Calle, que começa sua carreira artística anos depois do fim do movimento Situacionista, no final dos anos 70, traz em seu trabalho intenções e procedimentos que dialogam com a ideia de construção de situações momentâneas dentro do ambiente geográfico e afetivo. As ações de Calle quase sempre são apresentadas em forma de exposição e em seguida, publicadas em livros cuidadosamente editados, dispositivos potentes de leitura e fruição das situações criadas pela artista. Destaco aqui dois deles: Les Dormeurs ${ }^{7}$ (ação de 1979, livro editado em 2000) e Suite Vénitienne (ação de 1980, livro reeditado em 2015).

Em Les Dormeurs, primeira obra de Calle, não existe deslocamento da artista no espaço urbano e sim exatamente o contrário: ela convida 28 pessoas diferentes, entre conhecidos e desconhecidos, para dormir em sua cama. Calle criou uma situação que transforma os sentidos e afetos do espaço cotidiano mais íntimo, seu próprio leito, através da imprevisibilidade que traz o trânsito ininterrupto de pessoas. A ação foi por muito tempo um trabalho de exposição em galerias e museus: na parede, as fotos em preto e branco, formato paisagem, pontuadas por textos breves e, em frente às fotos, pousado numa mesa, um livro com relatos mais detalhados sobre cada adormecido. Publicado como livro pela editora francesa Actes Sud, Les Dormeurs apresenta-se numa caixa com dois volumes: em um deles, as fotos, pontuadas com as notas manuscritas e no outro, o texto integral da performance, que fora apresentado na mesa, no contexto da exposição.

Nas páginas iniciais do livro de texto, a artista resume em uma frase o que apresenta na sequência e que define todo o seu trabalho: "Provocação de situações arbitrárias que tomam a forma de um ritual: Os adormecidos".

\footnotetext{
${ }^{7}$ Os adormecidos (tradução nossa)

${ }^{8}$ Suíte veneziana (tradução nossa)
}

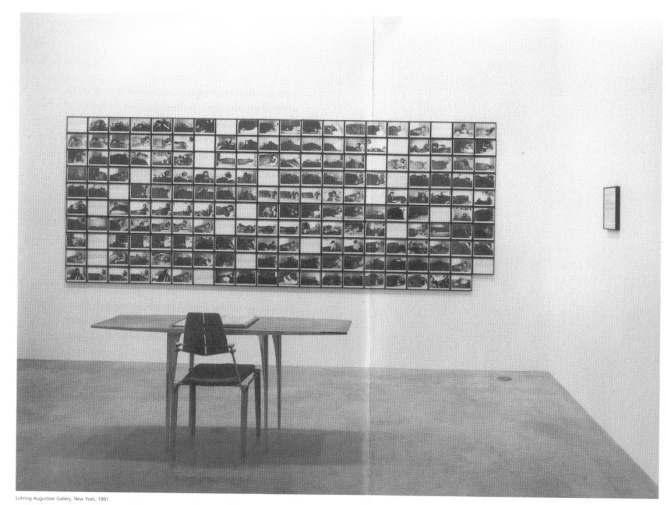

Figura 29 - Espaço expositivo de Les Dormeurs

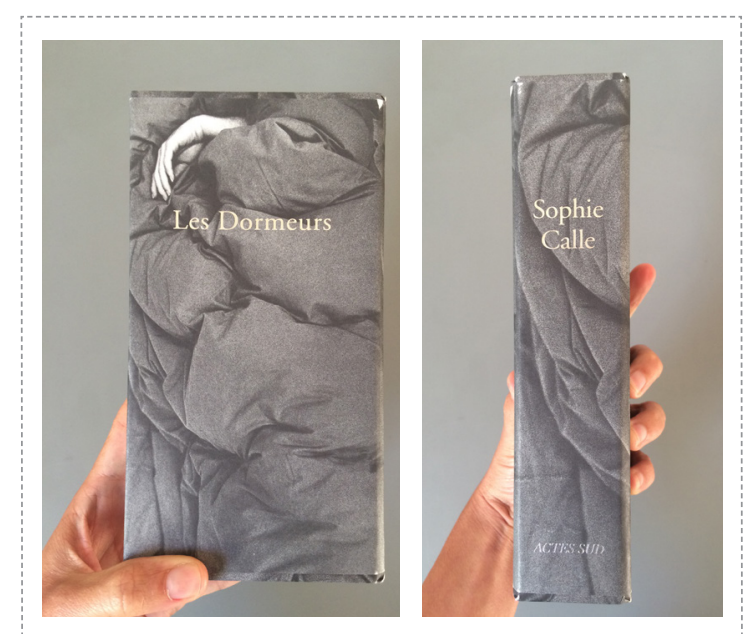

Figura 30 - Capa e lombada de Les Dormeurs 


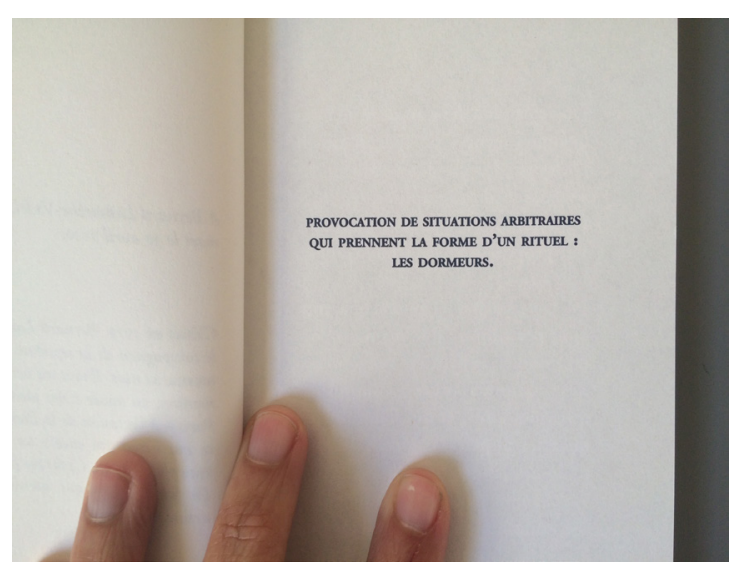

Figura 31 - Abertura de Les Dormeurs

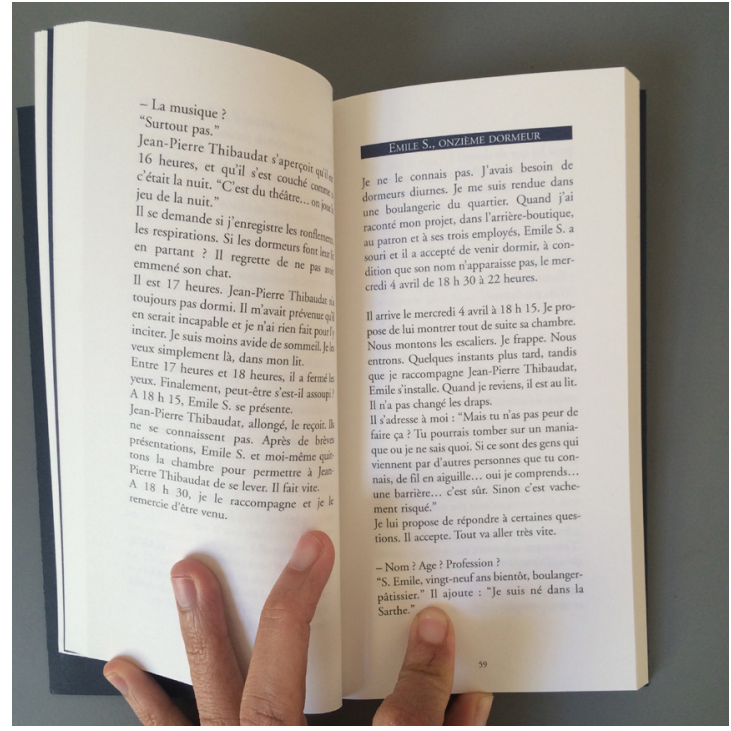

Figura 32 - Livro de texto de Les Dormenrs
Em seguida, ela explica como se deu a ação: "Pedi a algumas pessoas que me concedessem algumas horas do seu sono...", e detalha o procedimento: como fez para contactar as pessoas, quantas aceitaram, quantas recusaram etc. "Meu quarto deveria se transformar em um espaço constantemente ocupado durante oito dias, os adormecidos se sucederiam em intervalos regulares" (CALLE, 2000, p.10). Durante uma semana - de 1 de abril às 17 h a 9 de abril às 10:30 da manhã -, 28 pessoas se sucederam de maneira ininterrupta em sua cama. Amigos e desconhecidos, (indicados por conhecidos ou convidados por Calle), jornalistas, sua mãe, um aprendiz de padeiro do bairro, um ator, um cão que acompanha um dos participantes, uma babá... Calle aplica também um questionário a cada pessoa, para saber seu nome, idade, profissão, saber se dorme bem, se gostaria de mudar a roupa de cama etc. A artista tirou fotos dos adormecidos a cada hora.

Os textos no livro são breves, divididos em tópicos, por participante. A escritura é minimalista, sem grandes movimentos líricos e interpretativos. A artista descreve, conta, sem julgar.

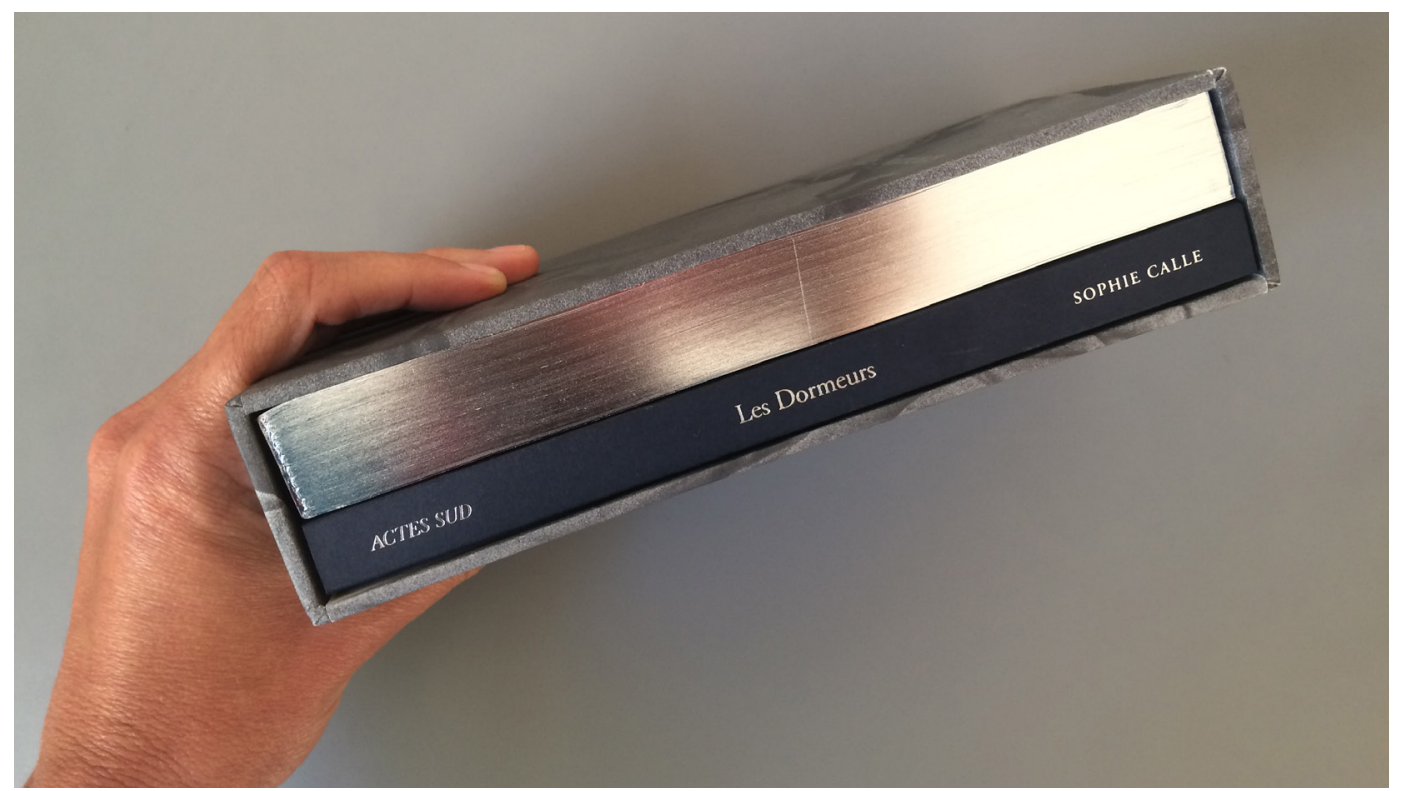

Figura 33 - Lombada prateada em Les Dormeurs 
SOPHIE CALLE

\section{Les Dormeurs}

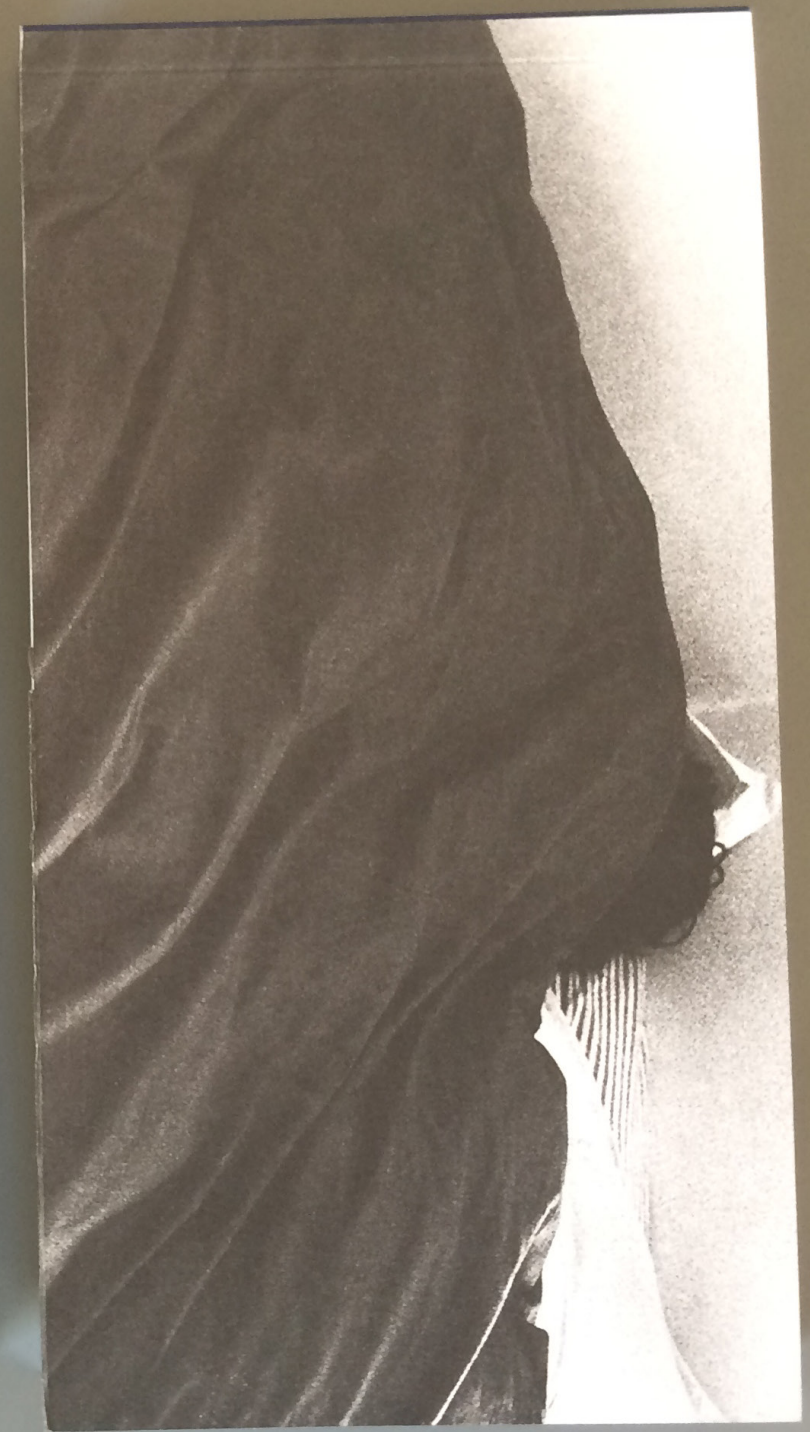


A caixa com os dois volumes tem $10,5 \times 20 \times 4,5 \mathrm{~cm}$ e traz o título gravado em relevo prateado sobre uma foto dos lençóis. Preto, branco, azul escuro e prateado são as únit cas cores presentes. Os textos aparecem em uma fonte serifada discreta e as anotações ao lado das fotos aparecem manuscritas com a letra de Calle. A lombada do livro de fotos é tingida de prateado, conferindo refinamento a este volume.
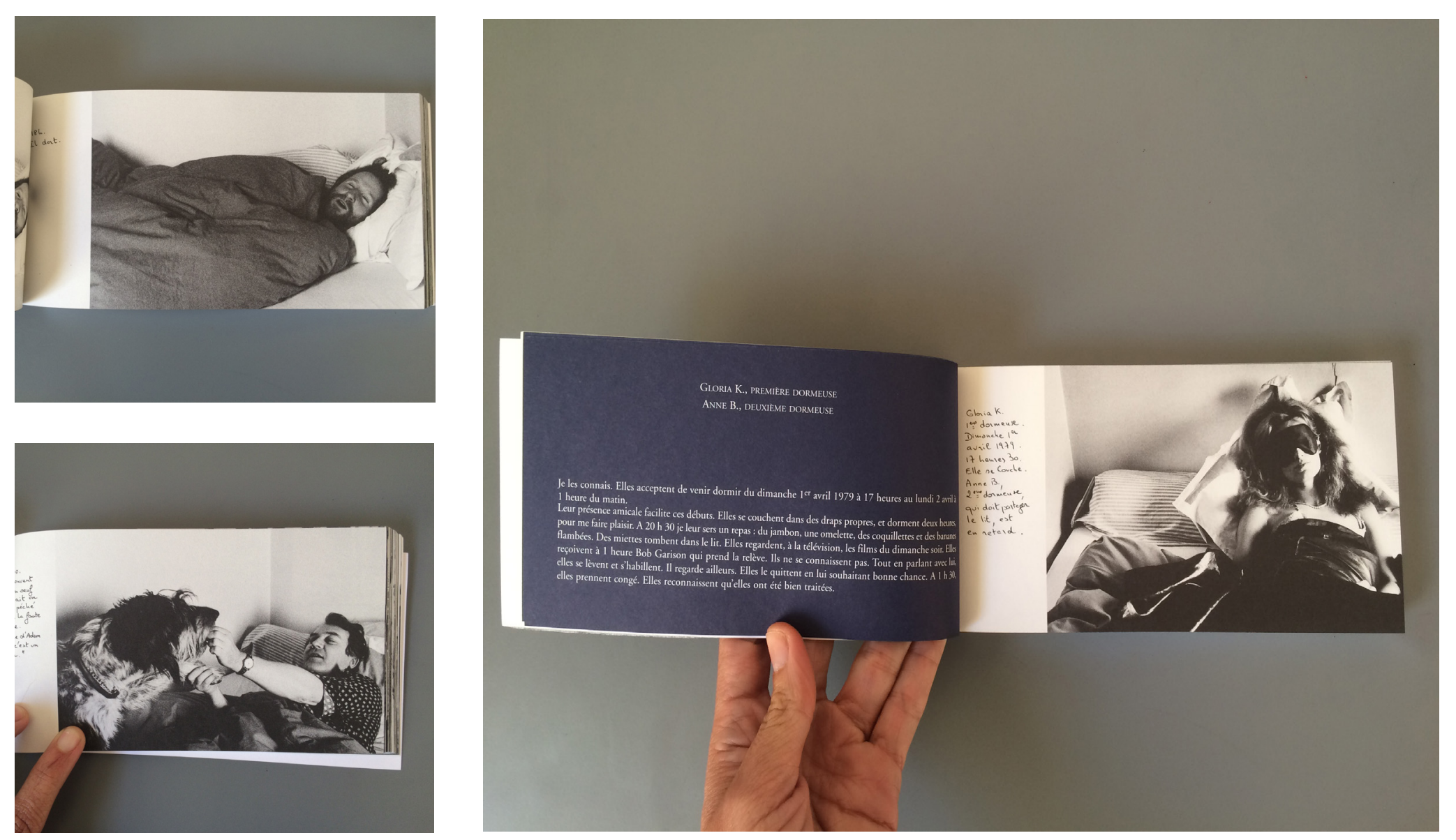

Figura 35 - Imagens internas do livro de fotos de Les Dormenrs 
Em seu texto, "As estratégias editoriais de Sophie Calle: Livros de fotografias, fotorromance, livros de artista", Cécile Camart (2015) descreve a reviravolta que a edição francesa sofre a partir de 1981, principalmente no que diz respeito à fotografia, consequência de inovações na produção artística que abrem espaço para uma nova forma de narrativa fotoliterária. A autora situa Sophie Calle nesse contexto, demonstra seu papel nesta renovação e sua relação com outros fotógrafos emblemáticos tais como Denis Roche e Bernard Plossu. Camart destaca que sua obra, ao mesmo tempo em que apresenta elementos do imaginário popular, do fotorromance, das mídias de massa, também apresenta sua porção de relíquia, do precioso, da coleção, combinando elementos autobiográficos com a ficção, trazendo resoluções plásticas que provêm de cadernos de estudo, iniciados por Calle na metade dos anos 1970.

Em Suite Vénitienne, na primeira página do livro a artista resume a situação que dá origem ao trabalho:

Por meses, eu segui estranhos na rua. Pelo prazer de segui-los, não porque eles particularmente me interessassem. Eu os fotografei sem que soubessem, tomei notas de seus movimentos e por fim os perdi de vista e os esqueci.

No final de janeiro de 1980, nas ruas de Paris, eu segui um homem ao qual perdi de vista alguns minutos depois na multidão. Naquela mesma noite, ele me foi apresentado em uma abertura de exposição. Durante nossa conversa, ele me contou que estava planejando uma viagem iminente para Veneza. Eu decidi segui-lo (CALLE, 2015, p. 1).

Durante duas semanas em Veneza, Calle anota os fatos ocorridos durante sua vigilância a Henri B., bem como suas próprias emoções enquanto procura-o, acha-o e segue-o através dos labirintos de Veneza.
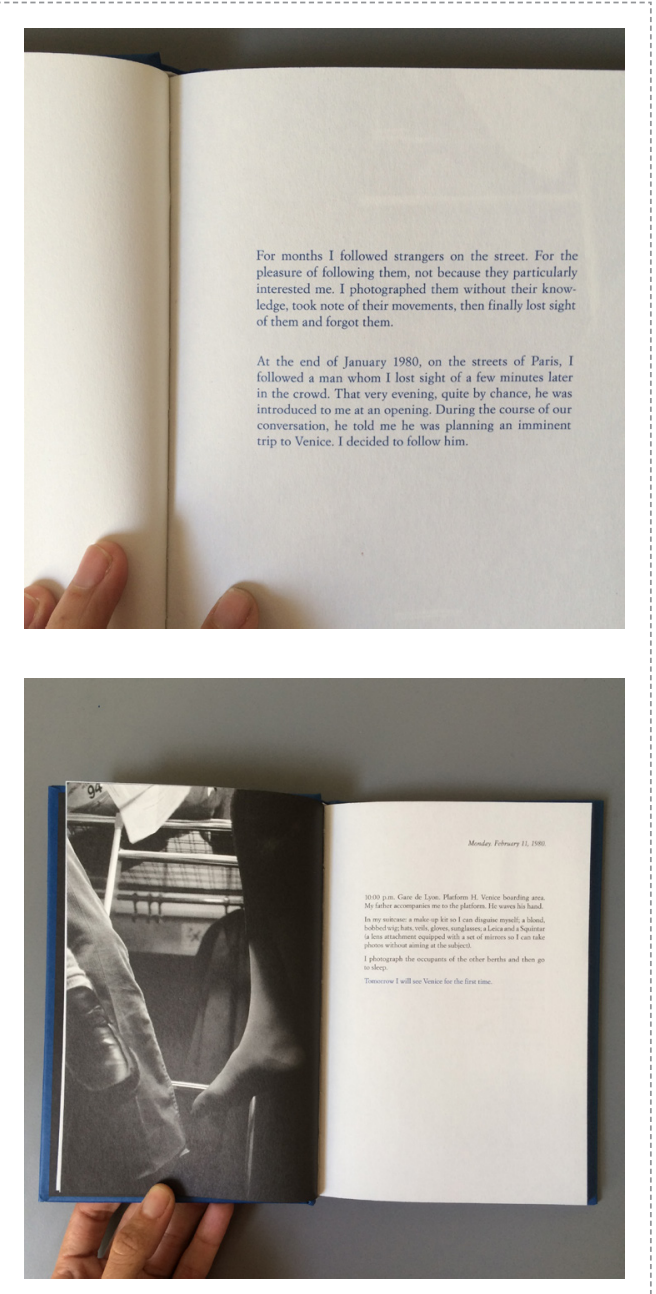

Figura 36 - Páginas internas de Suite Vénitienne 

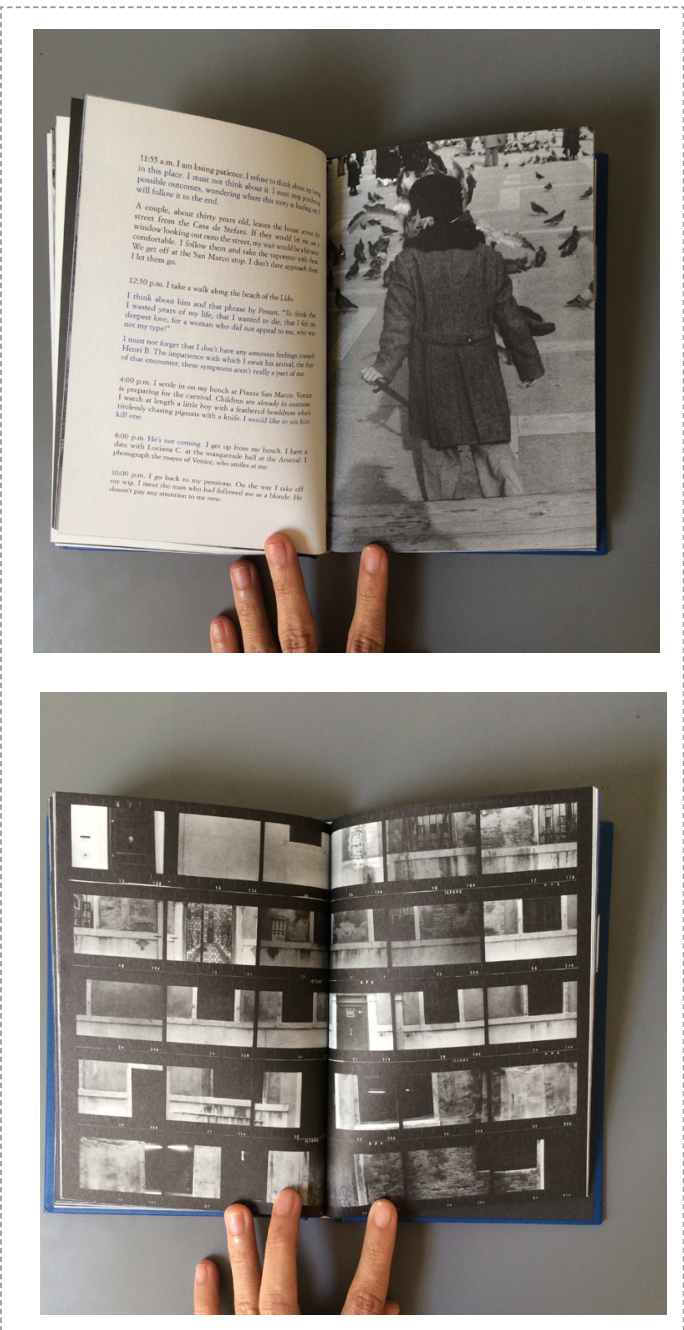

Figura 37- Páginas internas de Suite Vénitienne
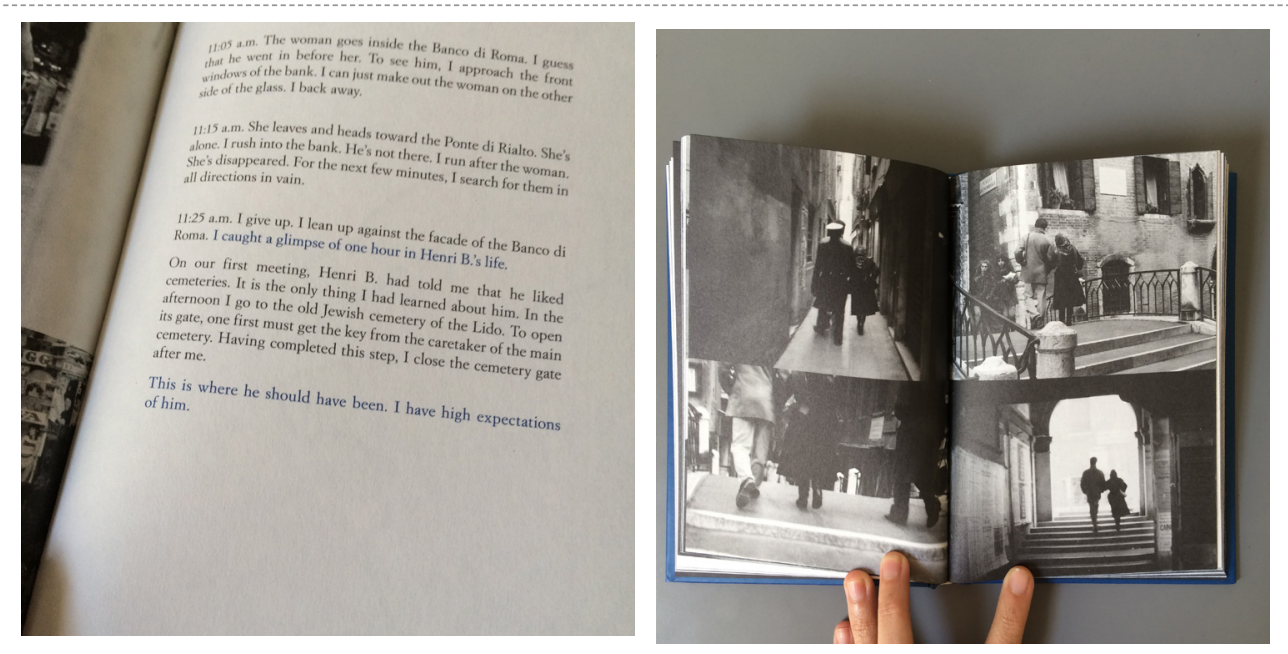

Figura 38 - Páginas internas de Suite Vénitienne

O livro é sobre o ato de seguir. O leitor se vê seguindo Sophie, que segue Henri B., num caminho trilhado à pé. As decisões de Henri B. dão o passo. As decisões de Calle - sua forma de narrar, as fotografias que escolhe apresentar - transformam a trilha em narrativa.

Mais uma vez, a imprevisibilidade, o erro, está no cerne conceitual do trabalho. Calle se preocupa em seguir, esse é o jogo. As imagens captadas são, durante o processo, um mistério para a artista, que só será desvendado no final, quando a experiência acabar. Paola Berenstein Jacques fala sobre a cegueira do "estado de corpo errante", que sente o espaço percorrido sem poder calcular os passos subsequentes, sem enxergar estrategicamente o que está sendo trilhado.

O estado de corpo errante pode ser cego, já que imagens e representações visuais não são mais prioritárias para a experiência errática. Para o errante, são sobretudo as vivências e ações que contam, as apropriações, com seus desvios e atalhos. A cidade é apreendida pela experiência corporal, pelo tato, pelo contato, pelos pés (JACQUES, 2012, p. 272). 

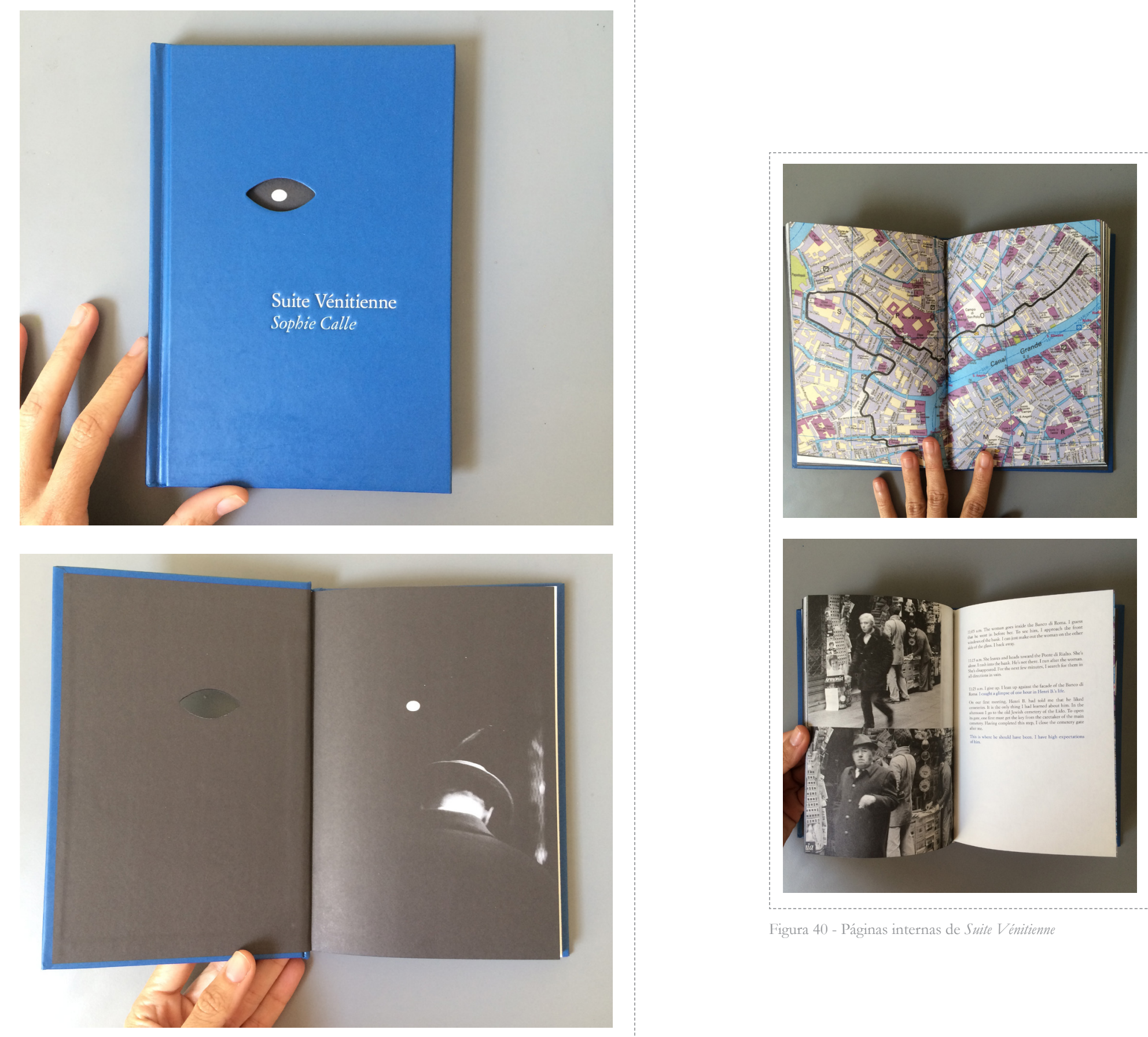

Figura 40 - Páginas internas de Suite Vénitienne 
A artista não está interessada naquele homem específico, mas sim, no encadeamento de situações a partir da ação de segui-lo. Henri poderia ser qualquer um. É impressionante como, ao olhar as imagens e o texto descritivo no livro, o interesse central da narrativa é o que não é revelado. Onde estaria Sophie Calle para conseguir tal enquadramento? Como ela fez para não ser vista? Como caminhava durante o ato de seguir? São questionamentos que permeiam toda a leitura.

Suite Vénitienne, foi lançado pela primeira vez em 1988 e ficou muito tempo fora de catálogo. Em 2015 foi relançado pela editora norte-americana Sigilo Press, em língua inglesa, tendo o design sido feito em colaboração direta com a artista. A capa dura traz um corte em forma de olho e o volume apresenta a lateral tingida de azul. O miolo contém 56 imagens em preto e branco entre fotos e ilustrações que acompanham a narrativa, impressas sobre papel japonês.

Deleuze e Guattari (1995) refletem sobre o próprio livro como mapa, multiplicidade móvel, feito de diferentes datas e velocidades, problematizando a noção de autoria como obra de um "eu". Seria, portanto, o contrário de um decalque da realidade, uma vez que não há um único sentido para a sua experimentação, são múltiplas as entradas, fazendo deste dispositivo, em si, uma cartografia pulsante.

Um livro não tem objeto nem sujeito; é feito de matérias diferentemente formadas, de datas e velocidades muito diferentes. Desde que se atribui um livro a um sujeito, negligencia-se este trabalho das matérias e a exterioridade de suas correlações. Fabrica-se um bom Deus para movimentos geológicos. Num livro, como em qualquer coisa, há linhas de articulação ou segmentaridade, extratos, territorialidades, mas também linhas de fuga, movimentos de desterritorialização e desestratificação (DELEUZE; GUATTARI, 1995, p. 12).

Podemos dizer que, para estes autores, um mapa, assim como um livro, não seria uma representação cristalizada, mas um elemento propositor de ações (ou "situações") sobre 
o "real”. É através dele que é possível desenharmos conexões, projetarmos movimento, entendermos através de que cadeias, pontos distantes podem se interligar. Um indivíduo que pega um mapa ou um livro lança sobre ele intenções pessoais, subjetivas, desejos, e estes são diferentes dos desejos de outros.

As ações de Calle e as derivas situacionistas expressas graficamente através dos mapas e livros citados materializam um tipo de experiência cada vez mais rara nas cidades contemporâneas: a experiência da alteridade. São "narrativas errantes", na expressão de Paola Berenstein Jacques. As derivas e errâncias poderiam permanecer na dimensão pessoal da vida do indivíduo que a praticou, mas o feito de transformá-las em relato, nas diversas formas possíveis, transmite a experiência ao expectador convertendo este em um participante ativo do percurso construído, ou seja, praticante desta arquitetura efêmera engendrada discursivamente. A narrativa, o relato, como diz Michel de Certeau, "não exprime uma prática. Não se contenta em dizer o movimento. Ele o faz." (CERTEAU apud JACQUES, 2012. p. 17). O mesmo autor diz que 'todo relato é um relato de viagem, uma prática do espaço.” (ibid., p.17) Deste modo, quem lê a bela edição de Les Dormeurs vela pelos adormecidos na companhia de Calle ao passo que cada leitor de Suite Venitienne caminha com a artista pelas ruas de Veneza, recriando o mapa feito inicialmente por ela e assim mantendo-o vivo.

Nas palavras de Jacques:

Essas narrativas errantes são narrativas menores, são micronarrativas diante das grandes narrativas modernas; elas enfatizam a questão da experiência, do corpo e da alteridade na cidade e, assim, reafirmam a enorme potência da vida coletiva, uma complexidade e multiplicidade de sentidos que confronta qualquer "pensamento único" ou consensual como o promovido hoje por imagens midiáticas luminosas e espetaculares das cidades (JACQUES, 2012, p. 20-21). 
No processo do narrar, do cartografar o deslocamento do corpo na pólis, a cidade-imagem, virtual, imaginada, previsível, estratégica e desabitada dá lugar à cidade-nómos, tática, tátil, sensorial, palpável, surpreendente, feita para pessoas. 
3.

Cidade Nômade 
ai, andei andei, não corro mais cada passo que eu dou me leva a calma chegou folha não partiu um pingo caiu, mas não machucou cada passo que eu dou me leva (Alessandra Leão, “Andei”)

Vimos que os trabalhos de Calle, bem como os dos Situacionistas Debord e Jorn, se desenvolvem em dois momentos: a concepção e desenvolvimento da estratégia de deriva e a posterior transformação da situação vivida a partir dela em narrativa. As ações arquitetam um espaço-tempo nômade dentro da cidade, através do percurso, que se torna perene através do relato. Careri busca desmentir o imaginário antiarquitetônico do nomadismo e, portanto do caminhar, propondo uma noção de arquitetura não como construção física do espaço, mas como construção simbólica do território. Nas palavras do autor:

A cidade nômade é o próprio percurso, o sinal mais estável dentro do vazio, e a forma dessa cidade é a linha sinuosa desenhada pelo subseguir-se dos pontos em movimento. Os pontos de partida e de chegada têm um interesse relativo, enquanto o espaço intermediário é o espaço do ir, a essência do nomadismo, o lugar em que cotidianamente se celebra o rito da eterna errância (CARERI, 2013, p. 42).

Sobre a noção de "percurso", ele explica:

Com o termo "percurso" indicam-se ao mesmo tempo o ato da travessia (o percurso como ação do caminhar), a linha que atravessa o espaço (o percurso como objeto arquitetônico) e o relato do espaço atravessado (o percurso como estrutura narrativa) (ibid., p. 31).

Quando Calle segue Henri B. pelas ruas de Veneza e os Situacionistas, por sua vez, criam estratégias para perder-se no espaço urbano, a cidade sedentária perde seus pontos de referência estáveis, fixos, orientadores. Em Cidade Passo, ao escolher de forma aleatória cinco bairros e sair em busca de pessoas que morassem neles para "entrevistar", elaborei 
um plano para criar meu próprio espaço nômade temporário, um percurso inédito, meu próprio "objeto arquitetônico".

A cidade é um campo demarcado, delimitado, com suas linhas de orientação fixas e funções determinadas. Deleuze e Guattari chamam essa zona de "estriada", própria da cultura sedentária. Porém, dentro do mesmo espaço estriado, existem zonas residuais, não funcionais, esquecidas, ditas "lisas" pelos autores, próprias do praticar nômade. O espaço estriado é visualmente reconhecível, determinado discursivamente, o liso, se vale de outros sentidos para ganhar significados, "é um espaço táctil, ou antes, "háptico", e um espaço sonoro, muito mais que visual" (DELEUZE; GUAT'TARI, 2012, p. 57).

Em seu Tratado de nomadologia: A máquina de guerra (2012), Deleuze e Guattari denotam que, diferente do praticado pelos habitantes da pólis - os sedentários -, para os nôh mades, os trajetos não estão subordinados aos pontos de chegada. O deslocamento não é um momento secundário na vida. Ele é central. Seu ethos, porém, se define por sua relação com o espaço e não propriamente por seu deslocamento puro e simples. Segundo os autores:

(...) ainda que os pontos determinem trajetos, estão estritamente subordinados aos trajetos que eles determinam, ao contrário do que sucede no caso sedentário. (...) um trajeto está sempre entre dois pontos, mas o entre-dois tomou toda a consistência e goza de uma autonomia bem como de uma direção próprias. A vida do nômade é intermezzo. Até os elementos de seu habitat estão concebidos em função do trajeto, que não para de mobilizá-los (DELEUZE; GUATTARI, 2012, p. 53).

\footnotetext{
${ }^{9} \mathrm{O}$ tato é uma modalidade sensorial cujos receptores estão espalhados por todo o corpo e que possui uma qualidade de ser uma próximo-recepção, sendo seu campo perceptivo equivalente à zona de contato. A percepção ótica se caracteriza pela organização do campo em figura e fundo. Já a percepção háptica é uma visão próxima, em que não vigora a organização figura-fundo. Os componentes se conectam lado a lado, se localizando em um mesmo plano, igualmente próximo. $\mathrm{O}$ olho tateia, explora, rastreia, o mesmo podendo ocorrer com o ouvido ou outro órgão. (KASTRUP, 2009, p. 41)
} 
Milton Santos (2009) chamou esses espaços indeterminados, nômades ou lisos de "opacos", considerando-os como abertos ao aproximativo e à criatividade, em oposição aos luminosos, considerados como fechados na exatidão, racionalizados e racionalizadores. O grande jogo do caminhar errante seria então a busca pelas opacidades dentro da cidade luminosa.

O nomadismo, na realidade, viveu sempre em osmose com a sedentariedade, e a cidade atual contém em seu interior espaços nômades (vazios) e espaços sedentários (cheios), que vivem uns ao lado dos outros num delicado equilíbrio de recíprocos intercâmbios (CARERI, 2013, p. 30).

A artista espanhola Lara Almarcegui, em seu projeto Guia de descampados (Guia de terrenos baldios) fotografa e cataloga espaços vazios no meio das cidades, terrenos que têm sua existência relacionada a "planos de urbanismo do futuro ou do passado que, por diversas razões, estão parados” (ALMARCEGUI, 2006). O guia foi feito em diversos países, inclusive em São Paulo, por ocasão da $27^{a}$ Bienal $^{10}$, em 2006.

Para a artista, os terrenos baldios são lugares em que "quase tudo é possível, porque neles não há nada, são lugares da possibilidade em que o cidadão pode se sentir livre” (ibid., 2006).

Os terrenos baldios (ditos terrain vagues) são espaços lisos e opacos por excelência. Esquecidos pelo mercado ou em situação de especulação, de espera, são microuniversos caóticos e indisciplinados dentro da ordem rígida do urbanismo.

Frequentemente nos terrenos baldios a natureza é muito selvagem e os terrenos podem ser utilizados para a observação de animais e plantas. Como os terrenos costumam carecer de manutenção, neles se podem observar processos naturais de decadência, mistura e entropia que se escondem no resto da cidade (ALMARCEGUI, 2006).

$1027^{\text {a }}$ Bienal de São Paulo. Como viver junto. Curadoria de Lisette Lagnado, Rosa Martinez, Adriano Pedrosa, Cristina Freire, Jochen Volz, José Roca (co-curador).

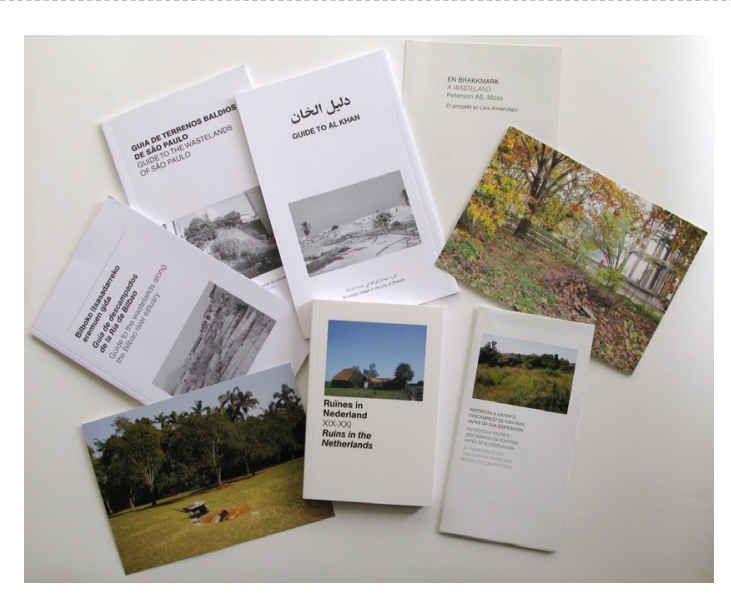

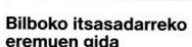

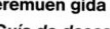

Guia de descampado

Guide to the wastelands along

Guide to the wastelands alon
the Bilbao river estuary

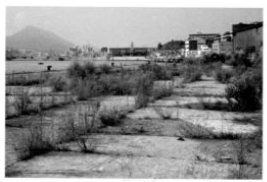

Figura 41 - projeto Guia de descampados, de Lara Almarcegui

ناخل GUIDE TO AL KHAN

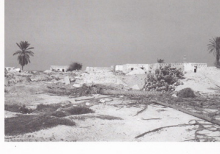

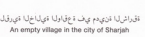

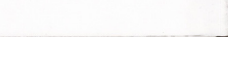



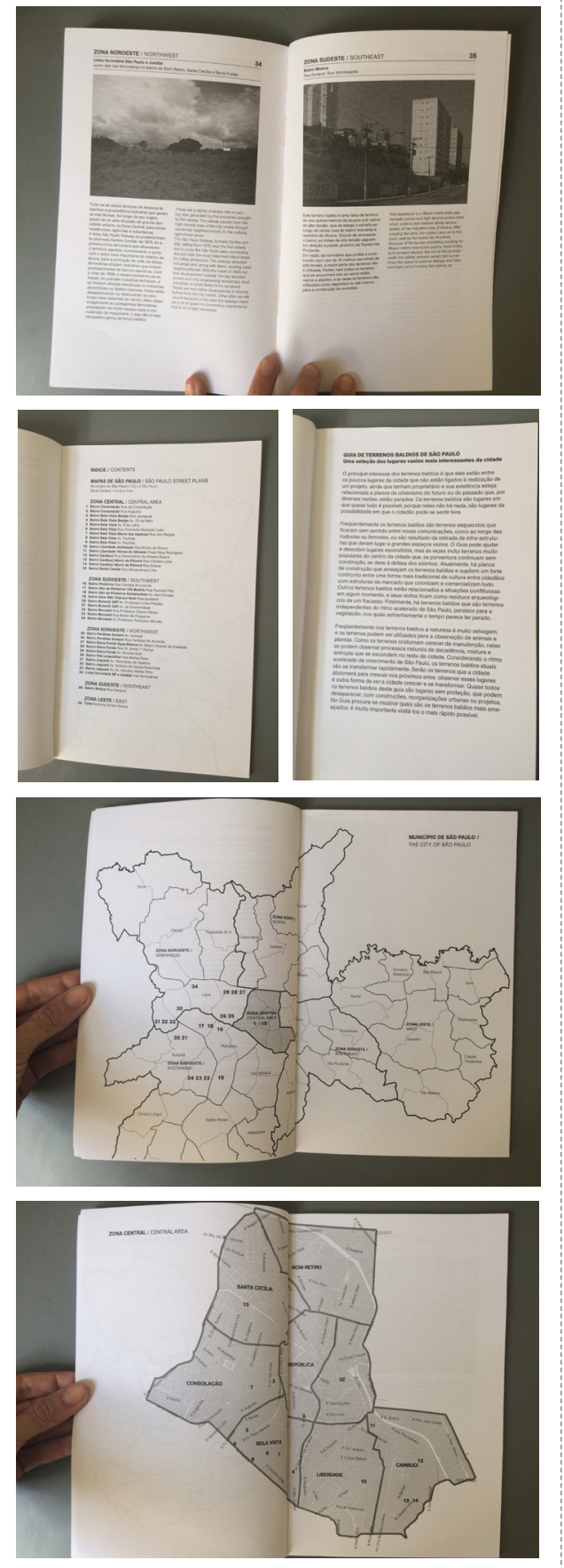

Figura 42 - Páginas internas de Guia de terrenos baldios de São Paulo

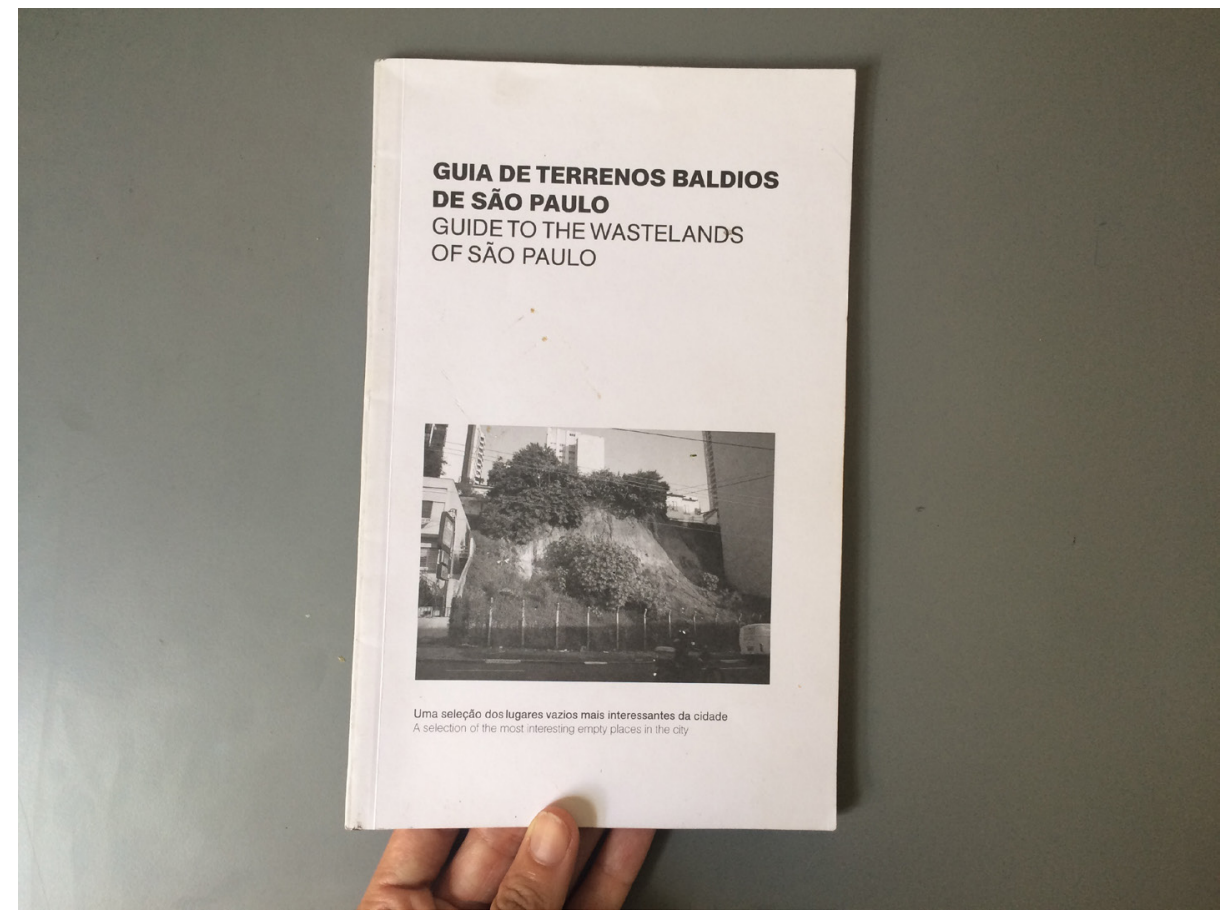

Figura 43 - Capa de Guia de terrenos baldios de São Paulo

Os guias são pensados para de fato serem utilizados pelo público. Trazem detalhada a localização dos terrenos catalogados (bairro, rua, número e indicação no mapa), o tamanho, quem é o proprietário e um pouco da história de cada um. Além disto, consta no texto uma descrição de como acessá-lo (por exemplo, "é fácil ter acesso pulando um muro que dá para a rua" ou "uma escada ao longo de sua lateral facilita o acesso"). A artista finaliza seu texto de apresentação com um convite: "No Guia, procura-se mostrar quais os terrenos baldios mais ameaçados: é muito importante visitá-los o mais rápido possível."

O trabalho tem um projeto gráfico bastante simples, impresso em preto e branco, em estilo "documental", sem rebuscamentos estilísticos. O guia ganha formato expositivo através de uma mesa onde são postos os impressos, que podem ser levados gratuitamente pelo público. Algumas vezes, também foram expostas as fotos em cores. 
Os terrain vagues são interstícios, brechas, zonas não estriadas na urbe, funcionam como “ilhas internas desabitadas" no espaço sedentário. São como seu avesso, seu contrário.

Parece, enfim, como a contraimagem da cidade, seja no sentido de uma crítica sua, seja no sentido do indício de uma sua possível superação. [...] A relação entre a ausência de utilização e o sentimento de liberdade é fundamental para compreender toda a potência evocativa e paradoxal do terrain vague na percepção da cidade contemporânea. $\mathrm{O}$ vazio é ausência, mas também a esperança, o espaço do possível. O indefinido, o incerto também é a ausência de limites, uma sensação quase oceânica, para retomar um verbo de Freud, a espera da mobilidade e da errância (SOLA-MORALES apud CARERI, 2013, p.43).

Ao listar e apontar no mapa esses vazios urbanos, Almarcegui cria uma espécie de "atlas" de espaços nômades, lugares sem espetáculo, não formatados como mercadoria e sem discursos de uso pré-determinados. Os terrenos baldios, em sua “inutilidade", são convites à experiências de corpo aproximativas à criatividade e à natureza.

Paola Berenstein Jacques apresenta como uma das "dinâmicas processuais errantes" a "incorporação", ou seja, o surgimento de um sujeito que "resiste à abstração dos números, ao império das estatísticas, à desmaterialização dos fluxos comunicacionais, ao comando do tempo sincrônico, à velocidade, à aceleração contínua da existência" (JACQUES, 2012, p.292).

O artista japonês On Kawara realizou, entre os anos de 1968 e 1979, os trabalhos I got up, I went e I met. Kawara realiza com esta longa série uma catalogação de eventos do cotidiano, conferindo importância e perenizando situações de seu corpo na cidade que normalmente seriam completamente esquecidas no tempo. Nestes eventos, o artista, que é sobretudo um viajante, sempre expressa um diálogo sutil com a urbe em que está naquele momento e deixa registrados os pequenos e grandes deslocamentos pelos quais passa durante a vida.

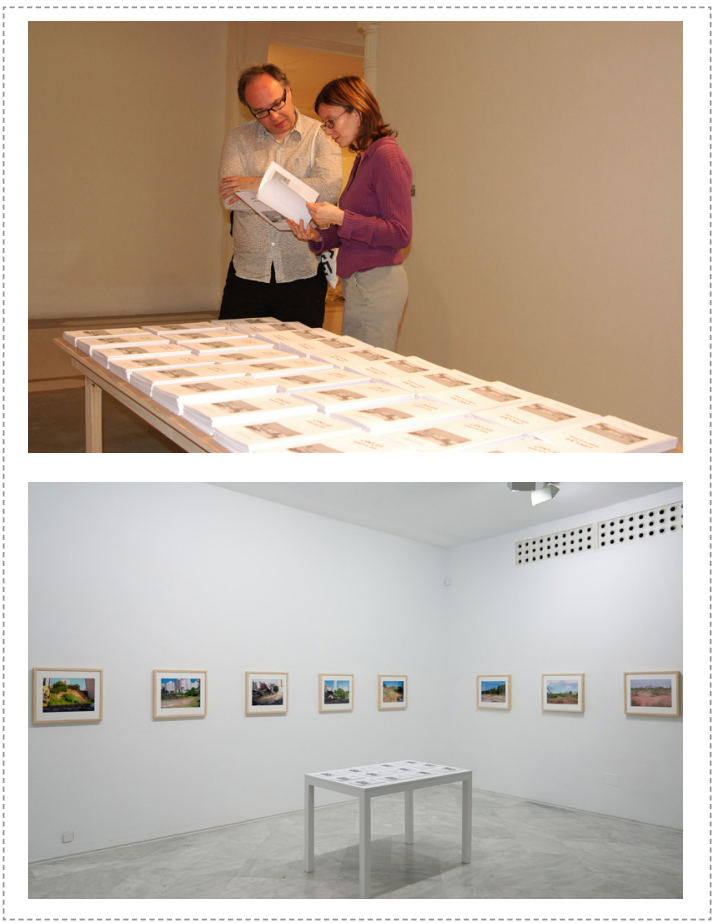

Figura 44 - Espaco expositivo de Guia de descampados 

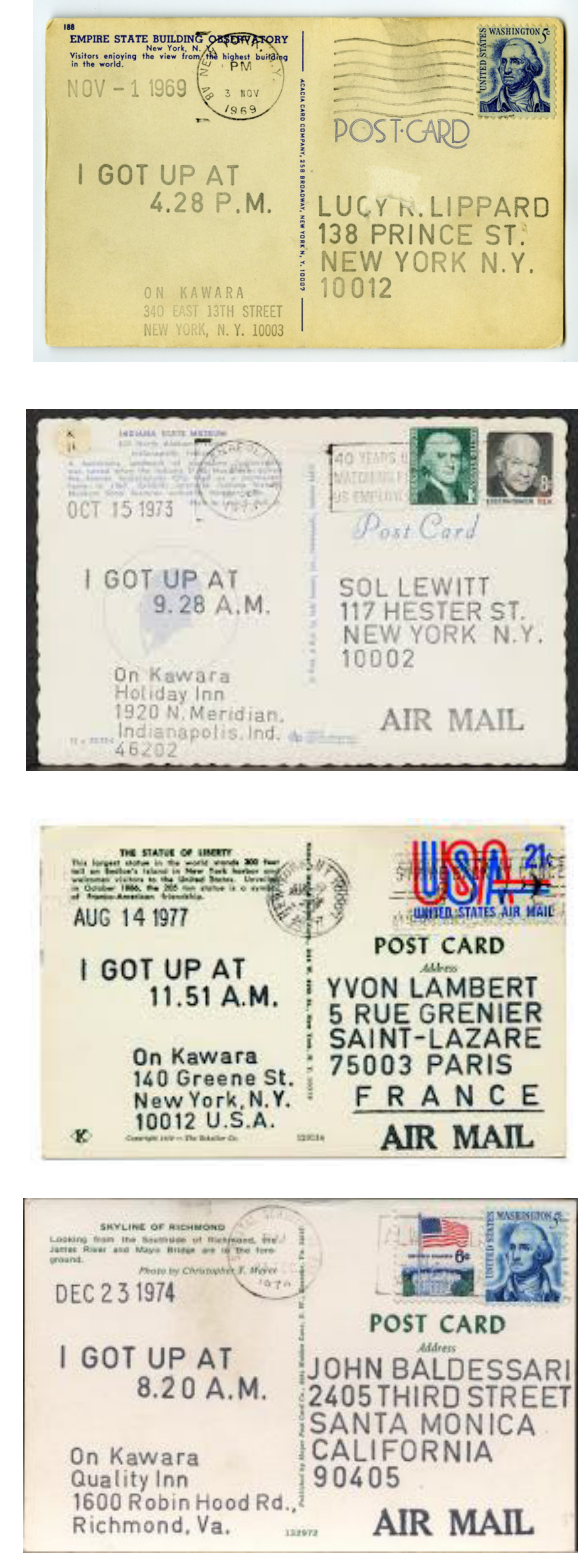

Figura 45 - Postais de I got up de On Kawara
Em I got up, Kawara enviou diariamente durante uma década um cartão postal da cidade onde estava a algum amigo ou amiga. No verso de cada, ele carimbou as palavras "I GOT UP AT" (eu acordei às), seguido do horário no qual despertou. A data, seu nome e o do destinatário encontram-se também carimbados. Muitos estão destinados a artistas e intelectuais renomados como John Baldessari, Sol Lewitt e Lucy Lippard.

Em I went, o artista guardou em fichários com folhas plásticas soltas, fotocópias de mapas com os percursos realizados por ele diariamente, traçados em linha vermelha. Cada dia deste período de 11 anos está catalogado em 20 volumes totalizando 4740 páginas.

Em I met, também diariamente, Kawara anotou, de maneira cronológica, o nome das pessoas com quem conversou. $\mathrm{O}$ artista anotava em cadernos e, quando não compreendia o nome dito pela pessoa por questões de diferenças de idioma, pedia para que ela anotasse ou lhe desse seu cartão de visitas.

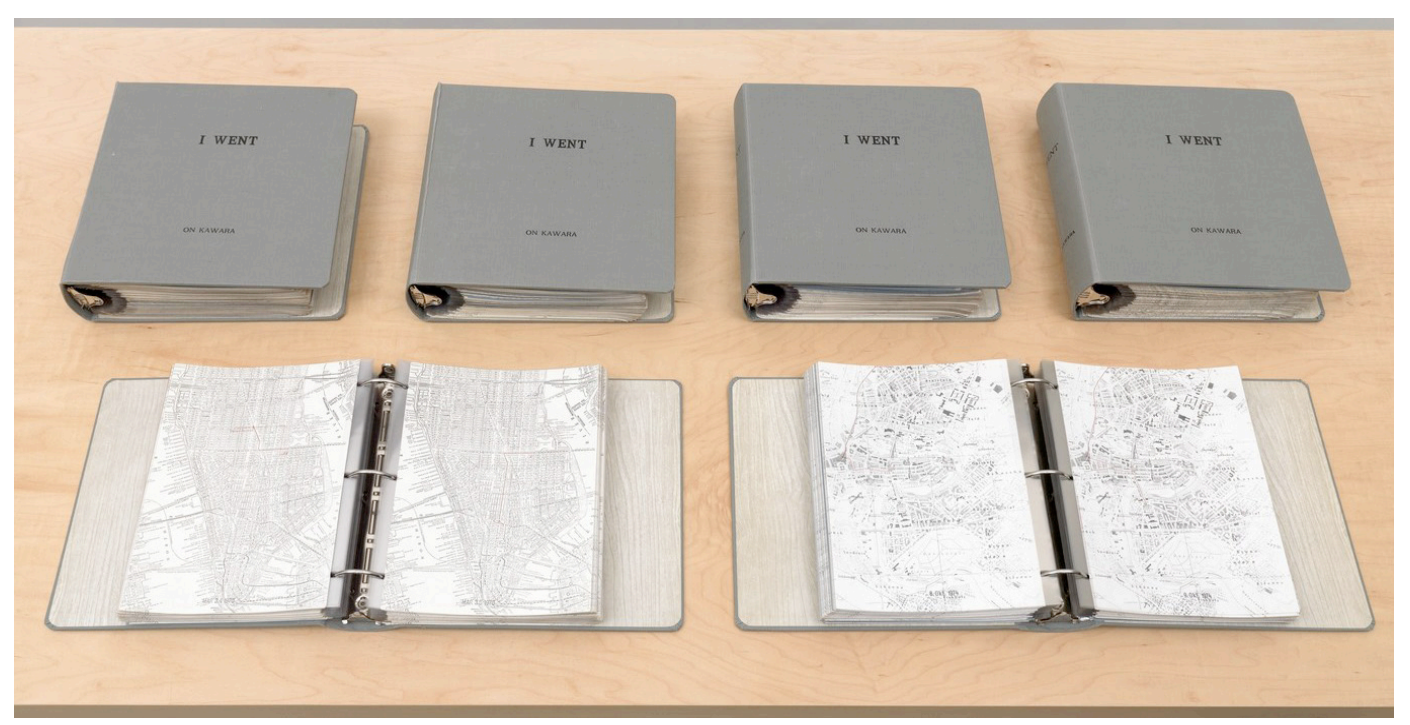

Figura 46- Originais de I went, de On Kawara 


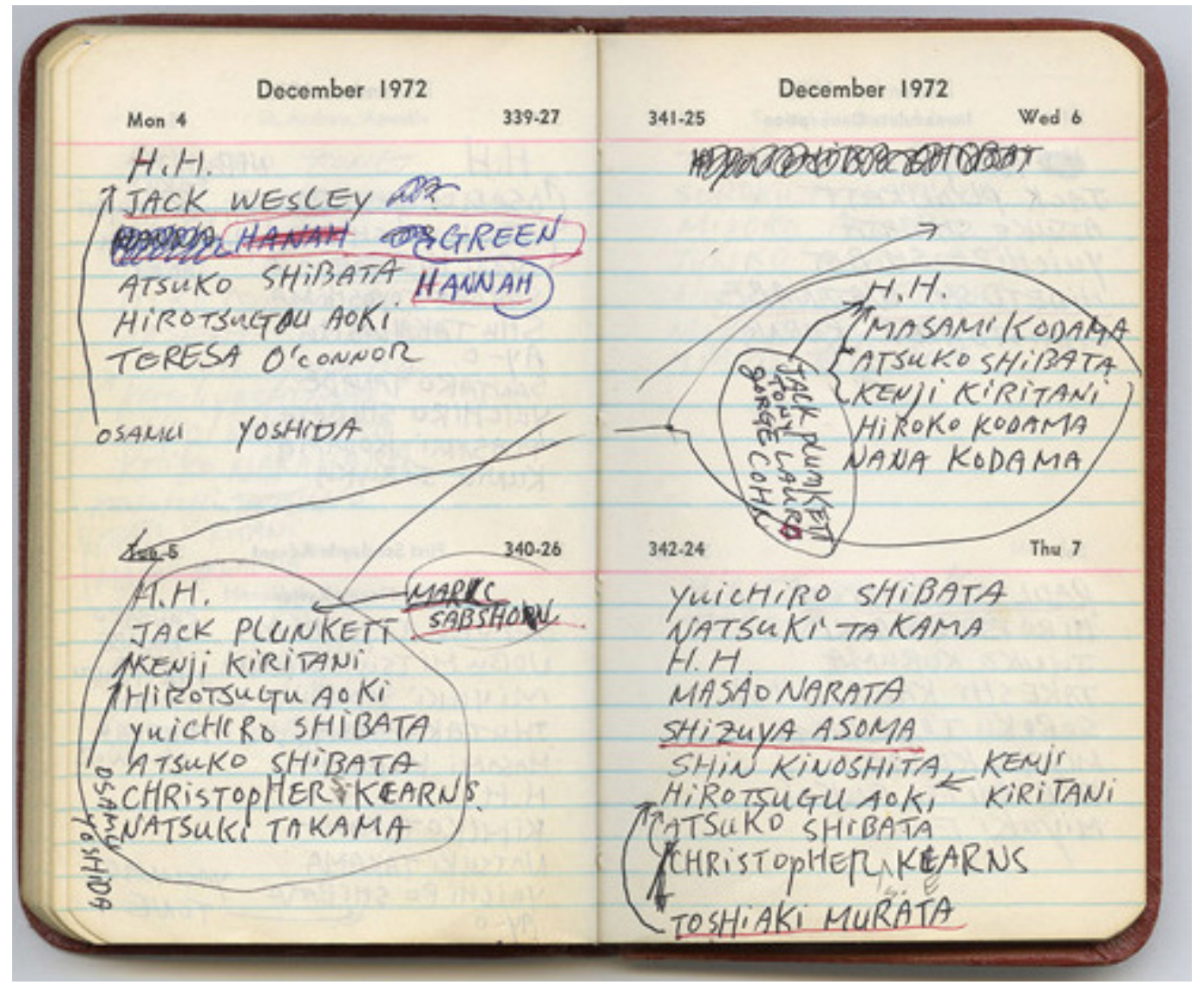

Figura 47 - Caderno de de I met, de On Kawara

Ao registrar sua rotina íntima nas metrópoles por onde passa, o artista desloca-se de sua condição de "praticante ordinário da cidade", de invisível, e realiza uma espécie de "cartografia corporificada", incorporando sua história pessoal a da própria cidade. Isto cria memória e ao mesmo tempo que abre possibilidades para ficções por parte de quem frui esse enorme material. 
I got up, I went e I met foram expostos em museus e hoje fazem parte de coleções importantes como a do museu Guggenheim. Recentemente, em 2008, toda a trilogia foi publicada pela editora de livros de artista Mfc-michèle didier, de Bruxelas. Cada uma das três partes está numerada e assinada pelo artista e a tiragem é de 90 cópias para cada um. Cada série tem encadernação em capa dura cinza com o título gravado em relevo e vem acomodada em uma caixa de madeira.

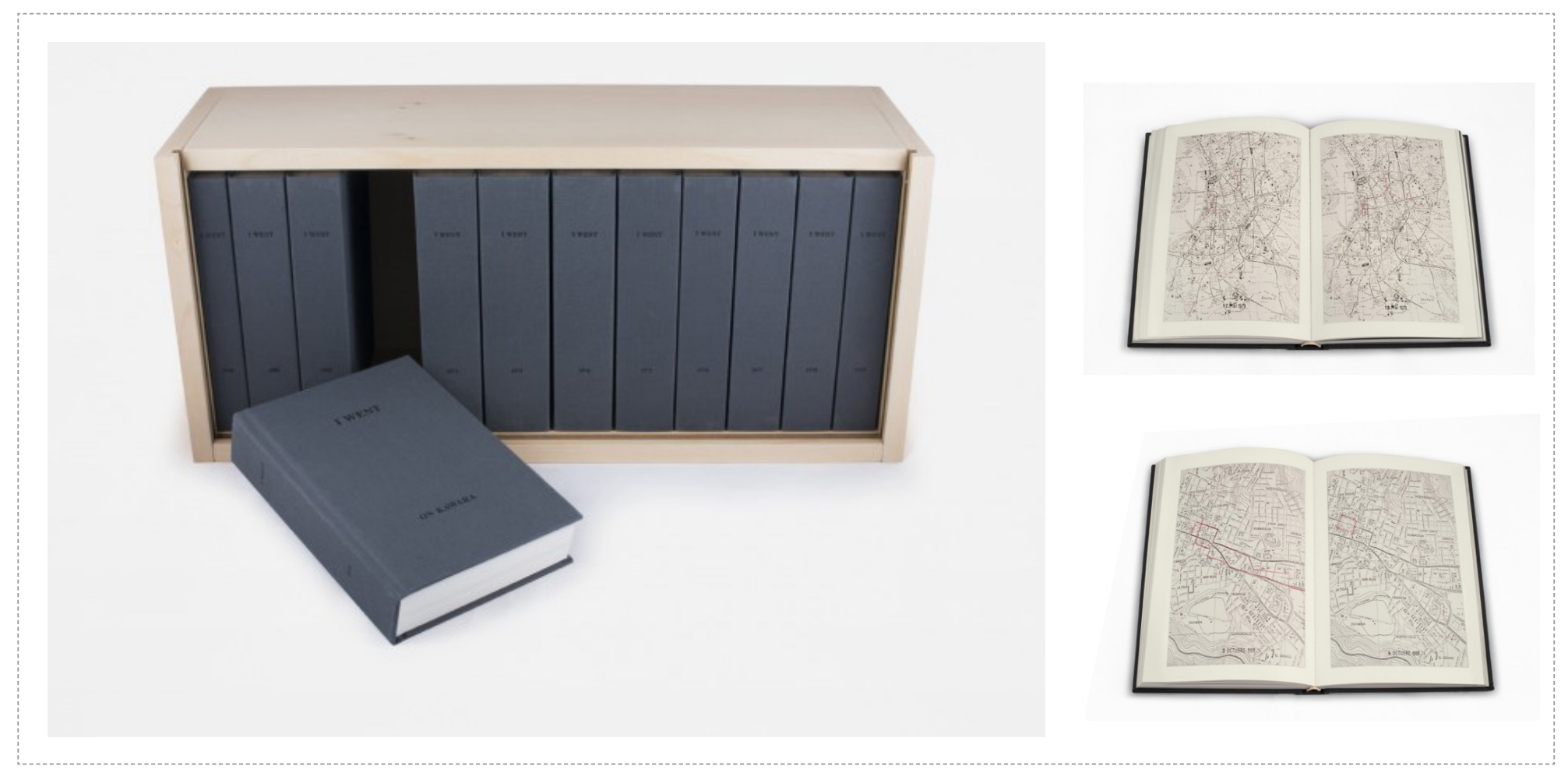

Figura 48 - Edição de I went, publicada pela editora Mfc-michèle didier, 2008 

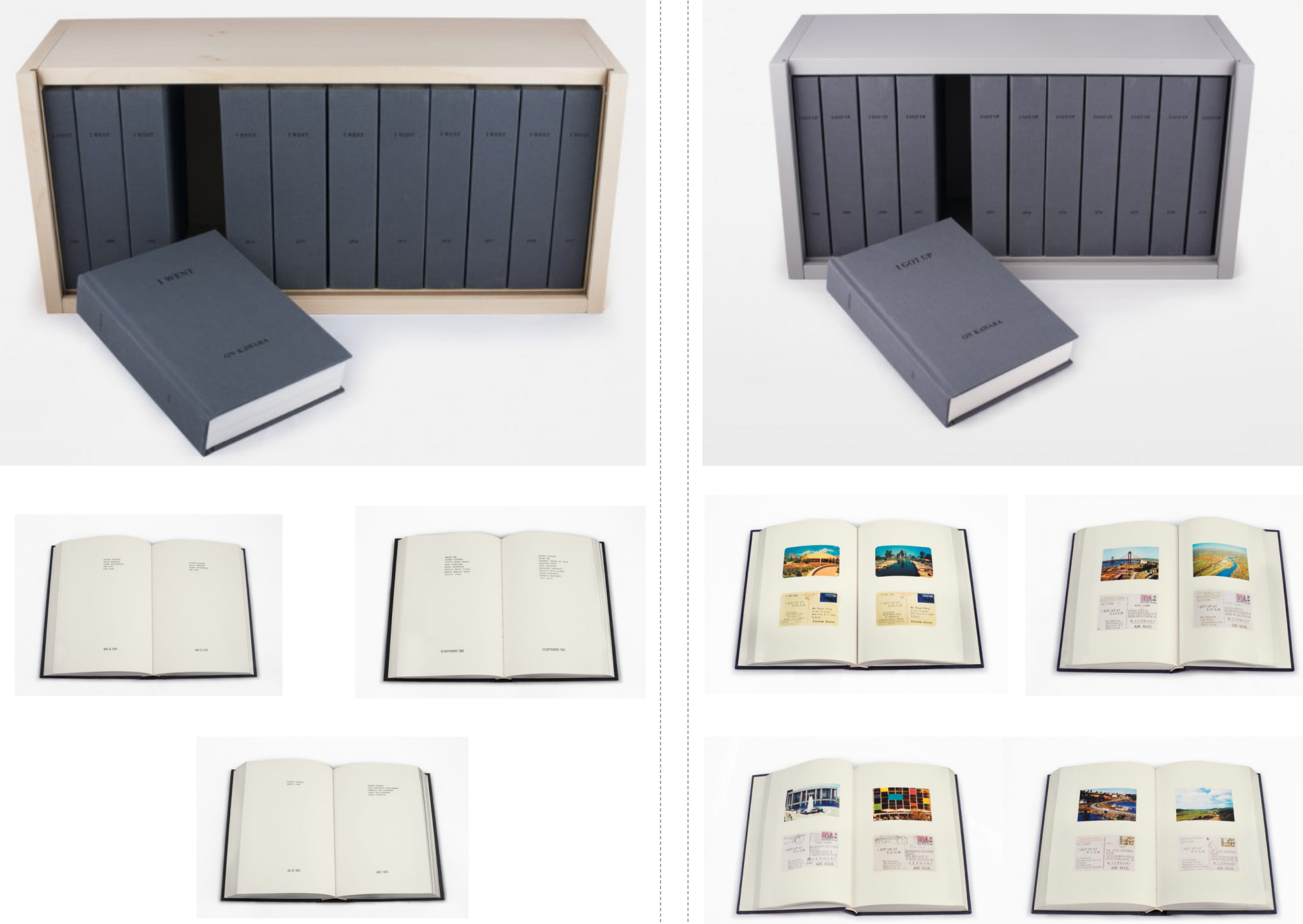
Em suas ações e seus subsequentes livros-mapas, tanto Almarcegui, quanto Kawara, instauram o mencionado nomadismo temporário, indo no sentido desejado por Debord quando defende a "construção concreta de ambientes momentâneos da vida e sua transformação em uma qualidade passional superior" (DEBORD, 1957). Ao permitir-se essa fruição, tanto o artista, quanto o público/ leitor/ usuário desenvolvem sentidos mais atentos, operam trocas mais carinhosas e lentas, menos predatórias com o espaço. Lara Leite Barbosa de Senne defende que, justamente em sua lógica de trocas com o ambiente, em lugar do acúmulo e descarte tipicamente sedentários, o nomadismo tem enormemente a agregar às estratégias de sustentabilidade das cidades. Do mesmo modo, o olhar mais detido e, por conseguinte, mais afetivo para o entorno pode ser um disparador de um novo tipo de consciência crítica. "O despertar da consciência regional é, antes de tudo o resgate de sentimentos, pensamentos e ações ecológicas" (BARBOSA, 2012, p.75).

Esse "resgate de sentimentos" refere-se à empatia com o espaço, prenhe de história e memória na medida em que é olhado sem que lhe seja imposto o ditame da "velocidade". Adriana Sansão Fontes cunha o termo "amabilidade urbana" para definir certos tipos de relações tecidas nos e com os espaços urbanos, a partir de determinadas ações:

Amabilidade significa a ação ou a qualidade de amável, o ato ou estado de comportamento que pressupõe a generosidade, o afeto ou a cortesia com o outro. É um termo que evoca a "proximidade" e a "abertura", seja em seu uso corrente, seja aplicada aos espaços urbanos, tal e qual aqui desejo cunhá-la: a amabilidade urbana. Nesse sentido, poderia considerá-la como um atributo do espaço amável, daquele que promove ou facilita o afeto e a proximidade, opondo-se ao individualismo por muitas vezes característico das formas de convívio coletivo contemporâneas (FONTES, 2011, p.24).

Por sua vez, Milton Santos ressalta que a imposição da velocidade às ações e ao pensamento humanos deteriora o sentimento de amabilidade, uma vez que não permite o tempo da identificação, do pertencimento: 
O mundo de hoje parece existir sob o signo da velocidade. O triunfo da técnica, a onipresença da competitividade, o deslumbramento da instantaneidade na transmissão e recepção de palavras, sons e imagens e a própria esperança de atingir outros mundos contribuem, juntos, para que a ideia de velocidade esteja presente em todos os espíritos e a sua utilização constitua uma espécie de tentação permanente. Ser atual ou eficaz, dentro dos parâmetros reinantes, conduz a considerar a velocidade como uma necessidade e a pressa como uma virtude. Quanto aos demais não incluídos, é como se apenas fossem arrastados a participar incompletamente da produção da história (SANTOS, 2001).

Thierry Davila(2002) traça um signo de equivalência entre caminhar e criar, e propõe o termo "cineplástica" (cineplastique, tradução nossa), entendendo o próprio movimento do corpo que anda como dotado de dimensão estética e significante. O andar - ou seja, traçar percursos em velocidade e escala humanas - pode ser visto não apenas como um simples deslocar-se, mas como um meio privilegiado para pôr-se em estado de escuta diante do mundo. O caminhante, ao percorrer o espaço, recria-o e cria-se. A cineplástica seria um processo de criação no movimento. No passo-a-passo inventa-se um agenciamento que será, ao mesmo tempo, um trajeto e a criação de uma forma corporal (DAVILA, 2002, p. 16, tradução nossa).

O fazer arquitetônico nômade tem como substrato, portanto, os caminhos percorridos, que ganham materialidade através dos relatos, das "narrativas errantes", que perenizam sua forma e multiplicam a experiência. O caminhante-arquiteto, ao fazer sua construção em movimento, tática, sem projeto, desestabiliza a fixidez do concreto urbano, ao mesmo passo em que recria sua própria forma corporal, seu ritmo de olhar e escutar, cria novos desejos em seu corpo-a-corpo com a cidade, que a cada encontro exige novos modos de existir e estar junto. 


\section{4. \\ devir-artista \\ devir-etnógrafa \\ devir-designer}


(Siegfried Kracauer)

O "homem lento" de Santos ou o "praticante ordinário da cidade", de Certeau, aquele que passeia sem destino ao sabor de um tempo sem pressa, foi consagrado na literatura por Charles Baudelaire como flâneur, mesmo antes da teoria da deriva Situacionista. O flâneur se lança à cadência dos acontecimentos no espaço urbano a "vagabundear", andar sem rumo, a seu bel prazer, incógnito, em meio à multidão. A flânerie surge no contexto da modernização das cidades no século XIX e resiste aos ditames do tempo acelerado inaugurado com a revolução industrial.

A multidão é seu universo, como o ar é dos pássaros, como a água, o dos peixes. Sua paixão e profissão é desposar a multidão. Para o perfeito flâneur, para o observador apaixonado, é um imenso júbilo fixar residência no numeroso, no ondulante, no movimento, no fugidio e no infinito. Estar fora de casa, e contudo, sentir-se em casa onde quer que se encontre; ver o mundo, estar no centro do mundo e permanecer oculto ao mundo, eis alguns dos pequenos prazeres desses espíritos independentes, apaixonados, imparciais, que a linguagem não pode definir senão toscamente. $\mathrm{O}$ observador é um príncipe que frui por toda parte o fato de estar incógnito (BAUDELAIRE apud JACQUES, 2012, p.40).

Nadja Monnet (2013) traça um paralelo entre a figura do flanêur e a do etnógrafo, considerando que ambos se colocam no lugar de escuta e observação do entorno, tendo a caminhada como uma técnica exploratória. Os antropólogos urbanos que se valem do caminhar, transformam esta prática de trabalho de campo num verdadeiro corpo-acorpo com a cidade, assim como o flâneur. O corpo físico do(a) pesquisador(a) toca e encontra o corpo da urbe nos espaços públicos da cidade.

O etnógrafo é aquele que se propõe o exercício do ver e do ouvir as dinâmicas de determinada cultura, num pretenso deslocamento de sua própria. O intento do pesqui- 
sador é se situar no interior do fenômeno por ele observado, através da participação efetiva nas formas de sociabilidade por meio das quais a realidade investigada se the apresenta. A interação é a condição da pesquisa, o encontro com a alteridade é o elemento primordial para desencadeá-la. Este não se dá de forma neutra, e pressupõe um registro seguido de uma narrativa. Uma escritura, que nunca é imparcial, sempre parte de um lugar de fala contaminado pelas vivências e intenções daquele que observa. Neste sentido, o método etnográfico e a arte se encontram, uma vez que necessariamente apresentam uma recriação da realidade vivida.

Sônia Vespeira de Almeida (2013) demonstra que o diálogo entre arte e antropologia tem assumido denominações várias - "etnografia espontânea", "sensibilidade antropológica”, ou "antropologia paralela" -, expressões que buscam traduzir as profícuas contaminações entre as duas áreas. Nesses processos artísticos-etnográficos, os recursos da antropologia são mobilizados nas práticas de arte em contextos experimentais que por vezes se aproximam de análises mais críticas do mundo, outras lançam proposições mais abertas, menos interpretativas. Traçam-se zonas de sobreposição. Os artistas operam recortes da realidade, através da criação de situações nas quais se apropriam de procedimentos etnográficos, e criam obras que são difundidas nos meios artísticos e editoriais.

Um exemplo desse tipo de apropriação é a chamada artetnografia, criada pela pesquisadora em artes cênicas Luciana Lyra, no âmbito do teatro. A artetnografia constitui-se como "um operador que promove contaminação entre atores/ atrizes e comunidades, sendo que estas são delimitadas a partir das dinâmicas pessoais dos artistas no processo de criação" (LYRA, 2013, p.29). O intuito do método não é propor análises e conclusões sobre o etnografado pelo artista, mas promover uma impregnação do mesmo com o que foi vivido naquela comunidade. Poderíamos dizer que o artista cria para si uma situação de etnógrafo, apropriando-se de metodologias como a pesquisa de campo, a observacão participante, entre outros, para a criação de seu personagem. 
Em meu próprio estado de devir artista-etnógrafa, descobri que, há alguns anos tem sido usadas técnicas de "entrevistas caminhantes", as walking interviews, em processos etnográficos, especialmente em pesquisas ligadas a comunidades nômades e estudos de antropologia urbana. A escolha desta abordagem baseia-se no argumento de que este tipo de procedimento, em certos casos, gera dados mais ricos, uma vez que os entrevistados são levados a dar respostas menos "prontas", estimulados pelos acontecimentos do entorno e pela paisagem (EVANS; JONES, 2011, p. 449).

Os autores afirmam ainda que, de maneira geral, as walking interviews foram estruturadas com o mínimo de questões prontas, feitas apenas para manter o ritmo da narrativa sobre as experiências do entrevistado no espaço, limitando-se a questionamentos baseados em coisas mencionadas no caminho (ibid., p. 851).

Comecei a materializar o trabalho com uma "pesquisa de campo" na forma do que chamei de entrevistas-passo. Estas se deram inspiradas livre e intuitivamente no método da cartografia, formulado por Gilles Deleuze e Félix Guattari. Não houve, portanto, coleta de dados, mas uma producão dos dados da pesquisa no sentido de provocar e acompanhar processos. Não se buscou estabelecer um caminho linear para atingir um fim. No método cartográfico, "objeto, sujeito e conhecimento são efeitos coemergentes do processo de pesquisar" (KASTRUP, 2009, p. 18). De fato, durante os encontros marcados quase sempre às cegas, os percursos, tanto do passo, quanto das conversas, foram sendo construídos ao sabor do acaso e das memórias de cada convidado. A partir disto, foram surgindo as formas e o próprio conceito do trabalho.

A cartografia como método de pesquisa-intervenção pressupõe uma orientação do trabalho do pesquisador que não se faz de modo prescritivo, por regras já prontas nem com objetivos previamente estabelecidos. (...) A diretriz cartográfica se faz por pistas que orientam o percurso da pesquisa sempre considerando os efeitos do processo do pesquisar sobre o objeto da pesquisa, o pesquisador e seus resultados (KASTRUP, 2009, p. 17). 

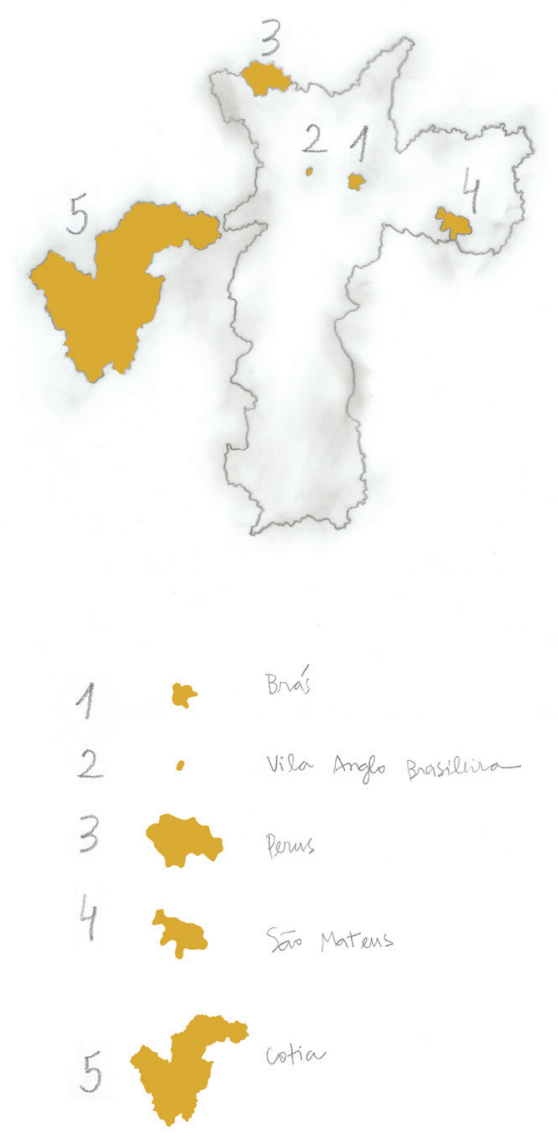

Figura 51 - Mapa de Cidade Passo
As escolhas iniciais do campo foram arbitrárias. Cinco localidades, em regiões aproximadas de norte, sul, leste e oeste de São Paulo. Ao todo foram feitas quinze entrevistas-passo. Três pessoas em cada lugar. Foram eles: Brás, Vila Anglo Brasileira, Perus, São Mateus e Cotia. As maneiras como encontrei cada um dos entrevistados foram diversas. No Brás conhecia um dos moradores, amigo de longa data e caminhante aficcionado, que me indicou os outros dois; na Vila Anglo, conhecia os três dos entrevistados, e nos demais lugares, não conhecia pessoalmente nenhuma das pessoas. Elas me foram indicadas por terceiros, em conversas informais.

O contato inicial com cada um se deu por telefone, e-mail ou rede social, em forma de convite a uma caminhada pelo bairro de residência de cada um, pelo trecho desejado por ele(a), durante o tempo que quisesse. Não houve nenhum tipo de critério na escolha das pessoas e todos os convidados aceitaram participar. O intuito único dessa estratégia foi conseguir que uma pessoa, sem roteiro prévio ou nenhum tipo de "programa”, aceitasse me levar para caminhar por lugares onde eu, por vontade própria, não poderia ter escolhido.

Nos encontramos sempre na data e local determinado pelo(a) convidado(a). As falas foram gravadas e as fotos foram feitas em um fluxo livre durante o trajeto, com a câmera do celular, sem grandes rebuscamentos técnicos. Não houve questionário prévio. Questões gerais iniciais eram colocadas como "você mora neste bairro há muito tempo?" ou "você costuma caminhar pelo seu bairro?" e a continuidade da conversa era dada pelas falas que surgiam no caminho. O percurso e duração foram de total decisão do(a) convidado(a).

A detecção e apreensão de material, em princípio desconexo e fragmentado, de imagens e discursos durante as entrevistas-passo, requereram uma concentração sem focalização, não-seletiva, sem objetivos prévios. Um estado de "espreita", aberto. Eu não 
sabia o que seria "aproveitado" daqueles registros, apenas me entreguei ao acaso de cada experiência, sem foco específico.

Em seu texto Os estados de atenção no trabalho do cartógrafo, Virgínia Kastrup define quatro variedades de atenção possíveis para o trabalho da cartografia: o rastreio, o toque, o pouso e o reconhecimento atento. Identifico o estado em que me encontrei nas entrevistas-passo como próximo ao rastreio. Nas palavras da autora:

O rastreio é o gesto de varredura do campo. (...) Em realidade entra-se em campo sem conhecer o alvo a ser perseguido; ele surgiria de modo mais ou menos imprevisível, sem que saibamos bem de onde. (...) A atenção do cartógrafo é, em princípio, aberta e sem foco, e a concentração se explica com uma sintonia fina com o problema. (...) O objetivo é atingir uma atenção movente, imediata e rente ao objeto-processo, cujas características de aproximam da percepção háptica (KASTRUP, 2009, p. 40).

Após as caminhadas, foi o momento de juntar todo o material e transformá-lo em um produto gráfico comunicante, relato da errância vivida através de um projeto de design de livro que não cristalizasse a experiência, mas que funcionasse como um convite a reverberações dos leitores.

Gui Bonsiepe descreve um conceito de designer enquanto propositor não apenas de formas, mas de processos. Processos que gerem discursos sobre o real, que problematizem a sociedade em que vivem, com uma postura crítica, para além da indiferença e do conformismo (BONSIEPE, 2011, p.36).

Projetar significa expôr-se e viver com paradoxos e contradições, mas nunca camuflá-los sob um manto harmonizador. $\mathrm{O}$ ato de projetar deve assumir e desvendar essas contradições em uma sociedade torturada por contradições, o design também está marcado por essas antinomias” (idem, p. 25). 
Nas entrevistas-passo pude apreender a cidade através de sensações sutis, vividas em lugares de beleza fora do padrão hegemônico, pasteurizado, "espetacularizado", gentrificado, que acabou se tornando imagem identitária de São Paulo. Ao digitarmos "São Paulo" na busca do google, o que aparece são fotografias aéreas, na qual se vêem arranha-céus, panorâmicas, quase sempre desprovidas de pessoas. Tive a oportunidade de caminhar, graças aos entrevistados(as), por uma urbe completamente distinta deste clichê. Bonsiepe considera uma virtude no design o respeito à alteridade (ibid., p. 39). A investigação para a produção do livro Cidade Passo foi uma entrega completa ao passo do outro.

Minha primeira caminhada foi com José Valdir, meu amigo de longa data, morador do bairro do Brás há mais de 10 anos. Eu já conhecia as ruas mais movimentadas do bairro: Gasômetro, Rangel Pestana, Piratininga. Nos encontramos em frente ao prédio dele (justamente na esquina da Rangel Pestana com a Piratininga) e saímos caminhando para fora do fluxo intenso. Entramos por ruas paralelas às avenidas, onde eu nunca havia pisado. De súbito, parecia que havíamos cruzado um portal pra outro lugar e mesmo outro tempo. Rua do Lucas, rua Vadico... Zonas com vilas de casas e prédios baixos de dois ou três andares pintados de amarelo claro, cor-de-rosa, com fachadas decoradas de rococós, mosaicos... a maioria decadentes, mas ainda delicadas, com arranjos de plantas nas grandes janelas. Chegamos a comentar, em pleno Brás, que aquilo parecia Paris, pela elegância das construções. José Valdir me indicou para as próximas entrevistas-passo Ivani, sua amiga e Enivaldo, padre da igreja Bom Jesus do Brás, morador de seu prédio.

Ivani escolheu começar pela zona cerealista - onde aproveitou para fazer compras para si - e em seguida me mostrar a igreja que frequenta e onde acontecem as festas típicas do bairro, a casa Lucce e a festa em homenagem a São Vito, resquícios da migração italiana. Me chama atenção a quantidade de vendedores ambulantes e de veículos de 
"tração humana", carrinhos de todos os tipos puxados por pessoas. Ao final, paramos para tomar uma água de coco e batemos papo com o vendedor que vem todos os dias de Santo André comercializar frutas no Brás.

Com Enivaldo, padre da igreja Bom Jesus do Brás há mais de dez anos, mal saímos da sacristia e, de cada três pessoas que passavam, uma o cumprimentava com simpatia. Ele pergunta se eu estou com fome e paramos para tomar um café com leite e bolo em uma padaria. Entramos em várias lojas para cumprimentar os vendedores e vendedoras, onde era sempre muito bem recebido. Parece que ele entende que, mostrar o bairro é mostrar as pessoas. Na rua do Gasômetro, entramos na loja de madeira de um conhecido dele e ali ficamos o resto do tempo juntos, ouvindo as histórias daquele homem sobre o bairro, sendo rodeados por um gato.

Na Vila Anglo Brasileira eu conhecia as três pessoas entrevistadas: Sandra, Felipe e Anahi. O bairro é basicamente residencial, de casas simples, baixas, muitas ainda sem muro alto na frente, nas quais se pode ver um pouco da parte interna, pedacinhos de intimidade através das cortinas. Por ser enladeirado, ali pude sentir na pele a "corporeidade lenta” que menciona Milton Santos.

Com Sandra, que é musicista e performer, tendo feito inúmeros trabalhos no espaço urbano, foi interessante discutir a potência possível de ações na rua, que geralmente são feitas em lugares de grande circulação, em locais como aquele bairro. Passamos por algumas pracinhas muito agradáveis e arborizadas, uma delas com paineiras altas, imponentes, cantinhos convidativos a sentar e ficar um tempo. Observamos os grafittis que preenchem muitos dos muros do bairro, alguns muito poéticos.

Felipe Julián começou me mostrando os "bares hipotéticos" que ele construiria no bairro, lugares que ele considera agradáveis para estar. Passamos pela travessa Roque 

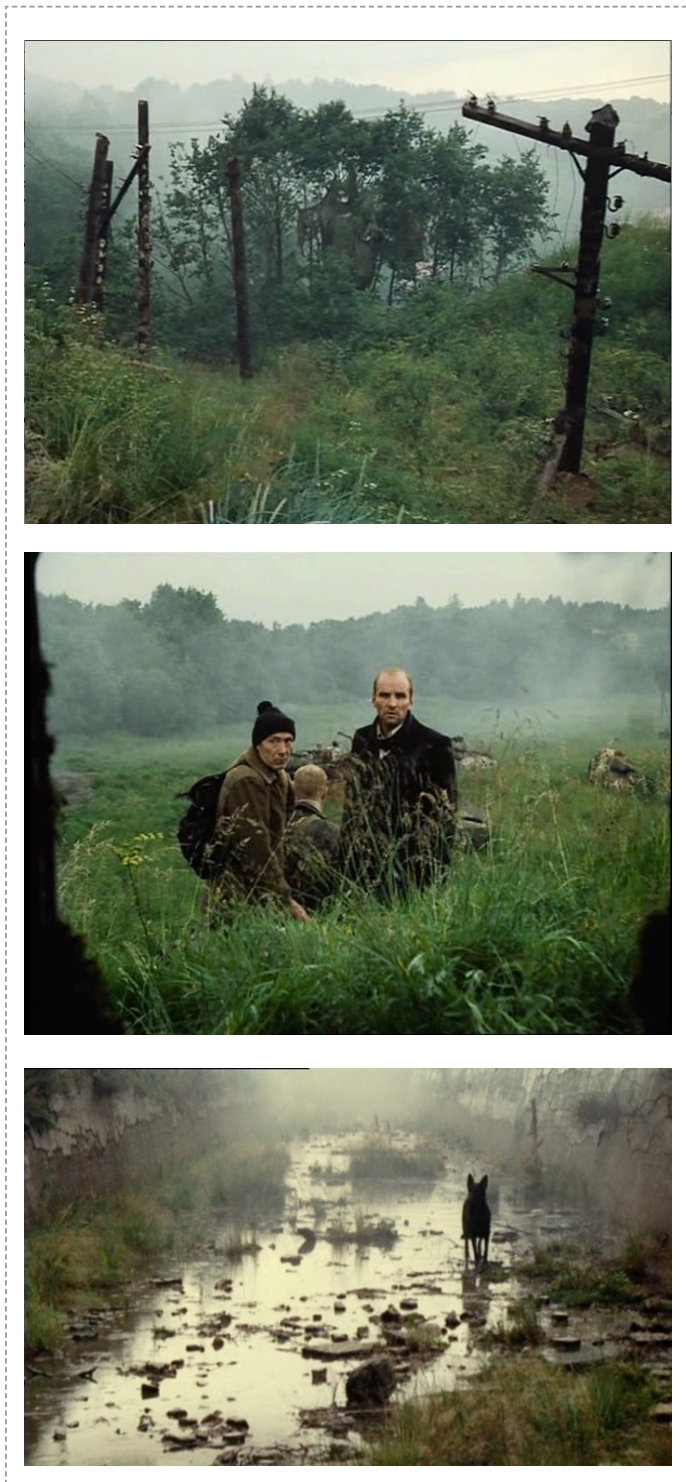

Figura 52 - Frames do filme Stalker, de Andrei Tarkovsky, 1979.
Adóglio, ruela cheia de graffitis por onde, no carnaval, passa um bloco chamado "Água Preta”. O nome é dado por conta do rio que flui por baixo do calçamento, de mesmo nome. Pegamos atalhos, ruazinhas sem asfalto, de terra e mato, pequenos vazios, lugares sem nome.

Com Anahi, que também é artista e tem uma pesquisa pessoal sobre os rios canalizados na região, discutimos o percurso do córrego Água Preta e as formas de reconhecer as nascentes urbanas que são muitas em toda a cidade de São Paulo, em especial na Vila Anglo.

Em Perus, fiz minha primeira entrevista-passo com Regina, professora e mulher extremamente ligada aos movimentos sociais naquele bairro. Quem me passou o contato dela foi uma colega do mestrado, que a conhecia. Regina foi criada em Perus e me contou sobre as transformações sofridas pela região ao logo dos anos, desde sua infância até hoje. A falta de cuidado, o lixo que se acumula, a poluição do córrego Ribeirão Perus, onde se banhava quando criança... Regina conta como isso destrói a afetividade por aquele espaço. No meio da caminhada com ela conheci Glauco e o convidei para a próxima entrevista-passo. Ao final do trajeto, fomos visitar o espaço cultural Quilombaque, que realiza inúmeras ações na comunidade, onde conheci Dedê (Clébio) que foi meu terceiro convidado de Perus.

Glauco escolheu me levar para um lugar não urbanizado em meio às construções, um terrain vague, abandonado, entregue à anarquia e exuberância da natureza. Fomos até o terreno de uma fábrica de cimento desativada, que foi muito importante para Perus nos anos 80 - inclusive foi o que trouxe o caráter militante que marca o bairro devido ao movimento sindical que existia ali. Essa caminhada me lembrou enormemente o filme Stalker, do diretor russo Andrei Tarkovsky. Os vazios, o verde, o silêncio, parecíamos estar muito distantes da urbe... em uma espécie de subconsciente da cidade.

Meu último convidado de Perus foi Clébio. Fomos até o Recanto dos Humildes, região no bairro com forte história política porque suas primeiras casas foram construídas 
em regime de mutirão, em 1989, apoiado pelo governo de Luisa Erundina. O Recanto começou com a implantação de um conjunto habitacional para abrigar famílias procedentes das áreas de risco da região, a maioria delas diretamente ligadas aos movimentos de luta pela moradia de São Paulo. Com a entrada de Paulo Maluf em 1992, a prefeitura interrompeu os processos de mutirão e ainda ameaçou as famílias de despejo. Foi cortada a verba para o programa, o que obrigou as pessoas a custearem sua própria casa. Isso proporcionou a ocupação de maneira desorganizada e a formação de diversas pequenas vilas, provocando um inchaço populacional no local. Em muitos momentos lembro de Salvador nesta caminhada pelo Recanto, sua urbanização desordenada, casas sem reboco, ladeiras íngremes e o calor daquele dia.

Em São Mateus, minha primeira caminhada foi com Vinicius, de 16 anos. Quem me passou o contato dele foi um rapaz que conheci em uma festa. Vou encontrá-lo em sua casa e, em princípio, ele demonstra uma certa preguiça, típica dos adolescentes, de sair para fazer a caminhada comigo. Eu insisto. Andamos nos arredores de sua casa e ele me mostrou o lugar que considera sua "segunda casa", a academia onde faz exercícios... Neste dia, na casa de Vinicius conheci Felipe Baldino, que me levou para a segunda entrevista-passo no bairro. Fomos para outra parte de São Mateus: o parque Zilda Arns, completamente abandonado pelo poder publico. Novamente penso em Stalker e o "subconsciente da cidade". A vegetação desordenada cobre o calçamento com um vigor impressionante. Baldino me conta que tem o sonho de ocupar aquele lugar com projetos culturais, música, poesia...

Fagner foi o terceiro convidado de São Mateus - me foi indicado por Clébio, de Perus - e a deriva com ele foi um tour pelos campos de futebol de várzea impressionantes do bairro. Ele começou me levando pra caminhar em um grande terreno particular, espécie de parque onde brincou durante sua infância. Caminhamos muito por aquele descampado cheio de ladeiras, relevo irregular, onde o mato cresce selvagem entre 
bancos e mesas de concreto espalhados, campinhos de várzea e quadras de esporte indefinido... Ali o gramado é capinado apenas em alguns lugares, sendo que em outros o mato é alto. A combinação confere um aspecto surreal ao lugar.

Cotia foi o último dos lugares onde derivei. Lembro-me que o escolhi pelo nome: "Cotia". Achei curioso. Um amigo comentou que sua mãe era de lá e fiquei com aquilo na cabeça. Peguei o contato dela, que veio a ser a última entrevista-passo, Enilda. Achei que Cotia era um bairro de São Paulo e só na primeira entrevista descobri que era outro município.

Gustavo foi o primeiro dos convidados em Cotia. Ele me foi indicado por uma amiga que participa da mesma banda musical que ele. Nos encontramos no metrô Butantã e de lá fomos. Passamos primeiro na casa de sua família, tomamos água, conhecemos seu quintal generoso e partimos pra explorar os arredores onde ele cresceu. Por indicação de um senhor que encontramos no caminho, fomos visitar uma árvore majestosa que havia perto dali... Terminamos no CEMUCAM, um parque maravilhoso, maior que o Ibirapuera, cheio de gente desfrutando da natureza.

Gustavo me indicou Wesllen, que mora no Mirante da Mata, periferia de Cotia, bem distante de seu bairro. Desci no fim de linha e esperei por ele em um bar onde os motoristas de ônibus ficam jogando sinuca. A deriva com Wesllen também evocou muitas memórias de sua infância de menino crescido na periferia, brincando solto na rua. Passamos por muitas crianças ocupando as calçadas com suas brincadeiras, jogando futebol.

Enilda foi a última pessoa com quem me encontrei. Seu bairro é o mais distante de todos, peguei um metrô e dois ônibus para chegar, em uma longa viagem pela Avenida Raposo Tavares. Nos encontramos em frente à padaria do bairro e saímos para caminhar em um dia quente de muito sol. Enilda conhece a todos na região, é cumprimentada 
com muita simpatia. Entramos primeiro na casa de seu irmão para tomar uma água e depois na de seu filho para tomar uma cerveja. Enilda me conta muitas coisas de sua vida pessoal e no final, me oferece um delicioso almoço - macarrão com calabresa - em sua cozinha, onde conversamos sobre coisas da vida (essas não estão transcritas no livro).

Terminada a "pesquisa de campo", me deparei com o desafio de elaborar o design de um livro que abarcasse um processo de encontro tão pessoal, rico e sinestésico como o das entrevistas-passo. O livro, em si, é uma experiência visual, ocular, mas em enorme medida, também tátil, também háptica. A textura do papel, o cheiro da tinta, o peso do objeto, o som das páginas sendo folheadas mediam a relação com o que está sendo visto/ lido. O designer, ao elaborar o projeto de um livro a partir de uma experiência de seu próprio corpo no espaço, fala deste, mas também fala também de si, de sua própria sensibilidade e cultura.

Existe uma série de exemplos de livro-objeto, cuja forma subverte a leitura canônica e busca ativar novas dinâmicas de relação, porém, para falar das entrevistas-passo, intui que o encontro com o leitor deveria ser da maneira mais simples possível. Escolhi propor para Cidade Passo o formato do códice ${ }^{11}$ - uma vez que reconheço a relação proporcionada por este como muito próxima a um passo-a-passo, a uma caminhada. Abri, contudo, a possibilidade para que o usuário não fique preso a ele. O livro é montado na forma de um arquivo-fichário, com folhas que podem se soltar a depender da vontade. Não é imprescindível à experiência movê-las, mas é possível que cada um promova sua própria leitura em deriva, caso queira.

${ }^{11}$ Códice (do latín codex, -icis) é o formato de livro mais comum que conhecemos. Se compõe de cadernos colados, costurados e encadernados. O códice surge na antiguidade como um avanço ao rolo de pergaminho, e gradualmente foi substituindo este último como suporte de textos e imagens. 

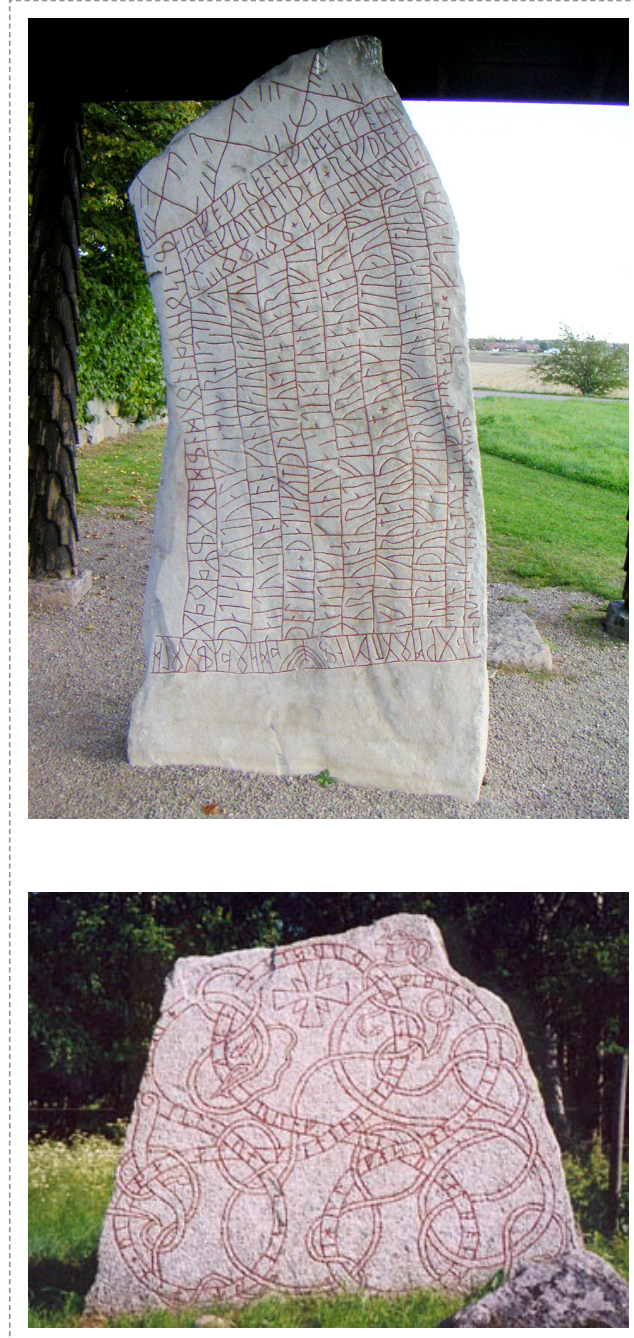

fig. 53 - Pedras rúnicas do século IX e século XII encontradas na escandunávia
O material coletado foi basicamente fotográfico e de texto (áudios transcritos), mas, no desenvolvimento da investigação sobre grafismos dos mapas, uma certa iconografia ficou presente no meu imaginário, que é a do que chamo de "cartografias do intangível”. Sistemas cartográficos divinatórios, que buscam delinear trajetos para além do espaço-tempo presente, que espelham desejos, possibilidades, transcendendo o espaço, ampliando seus sentidos. Um desses sistemas em especial aparece citado na apresentação do livro, de maneira metafórica: As runas.

As letras rúnicas ou simplesmente runas ${ }^{12}$ são alfabetos usados para escrever nas línguas germânicas da Europa do Norte, principalmente na Escandinávia, ilhas Britânicas e Alemanha (regiões habitadas pelos povos germânicos) desde o séc. II até ao séc. XI. Estes caracteres têm sido encontrados majoritariamente inscritos em pedras, e em menor número, em ossos e peças de madeira, assim como em pergaminhos e placas metálicas.

O livro traz como imagem da capa uma analogia à essa antiga escritura, uma espécie de São Paulo "rúnica", fragmentada, cujos trechos das caminhadas feitas nas entrevistas-passo se misturam com outros feitos por mim em outros momentos da vida. Esses fragmentos, essas linhas, formam figuras, desenhos, que poderiam, se fizermos um exercício lúdico, trazer sentidos divinatórios. A capa é portanto um convite a imaginar a cidade mesma enquanto oráculo possível.

$\mathrm{Na}$ quarta capa, a imagem de um matagal, fotografia feita na entrevista-passo de Perus. O mato aparece aqui como representação de um espaço não-domesticado, "liso" (Deleuze/ Guattari) ou “opaco" (Milton Santos), aberto a possibilidades e a imprevisibilidades.

\footnotetext{
${ }^{12}$ Segundo a lenda da criação mítica das runas, o deus Odin após longo sacrifício (permanecer imóvel e sozinho durante nove noites, atado a uma àrvore, de ponta cabeça), teve um vislumbre e trouxe para a humanidade essa escrita alfabética antiga, cujas letras possuíam nomes significativos e sons também significativos, e que eram utilizadas na poesia, nas inscrições e nas adivinhações, mas que nunca chegaram a ser uma língua falada.
} 

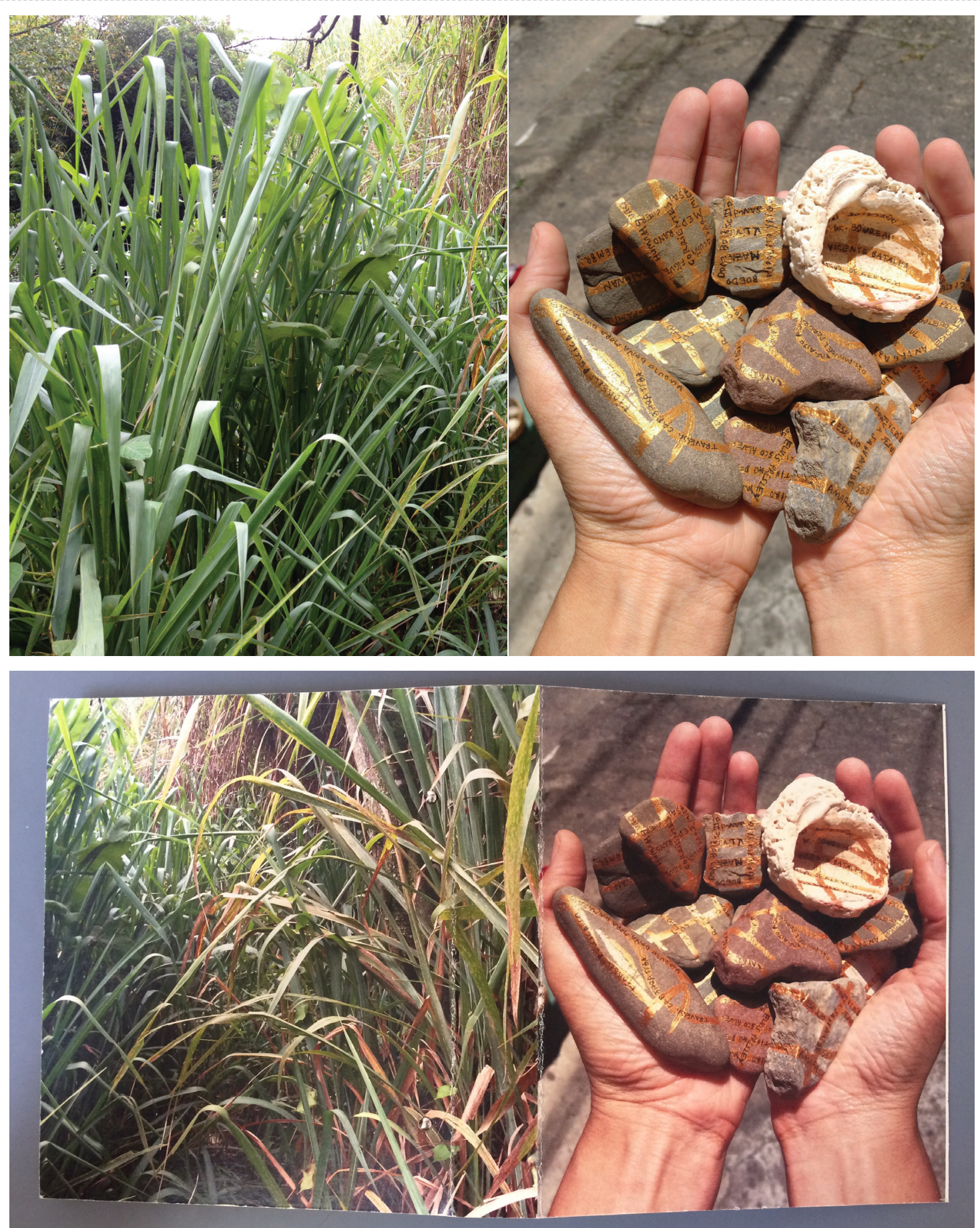
Atravessando o envoltório que protege e oferece o livro, iniciamos a experiência propriamente dita. O volume abre com imagens de cada um dos entrevistados(as) e, ao seu lado, o traçado da região que caminhamos juntos.
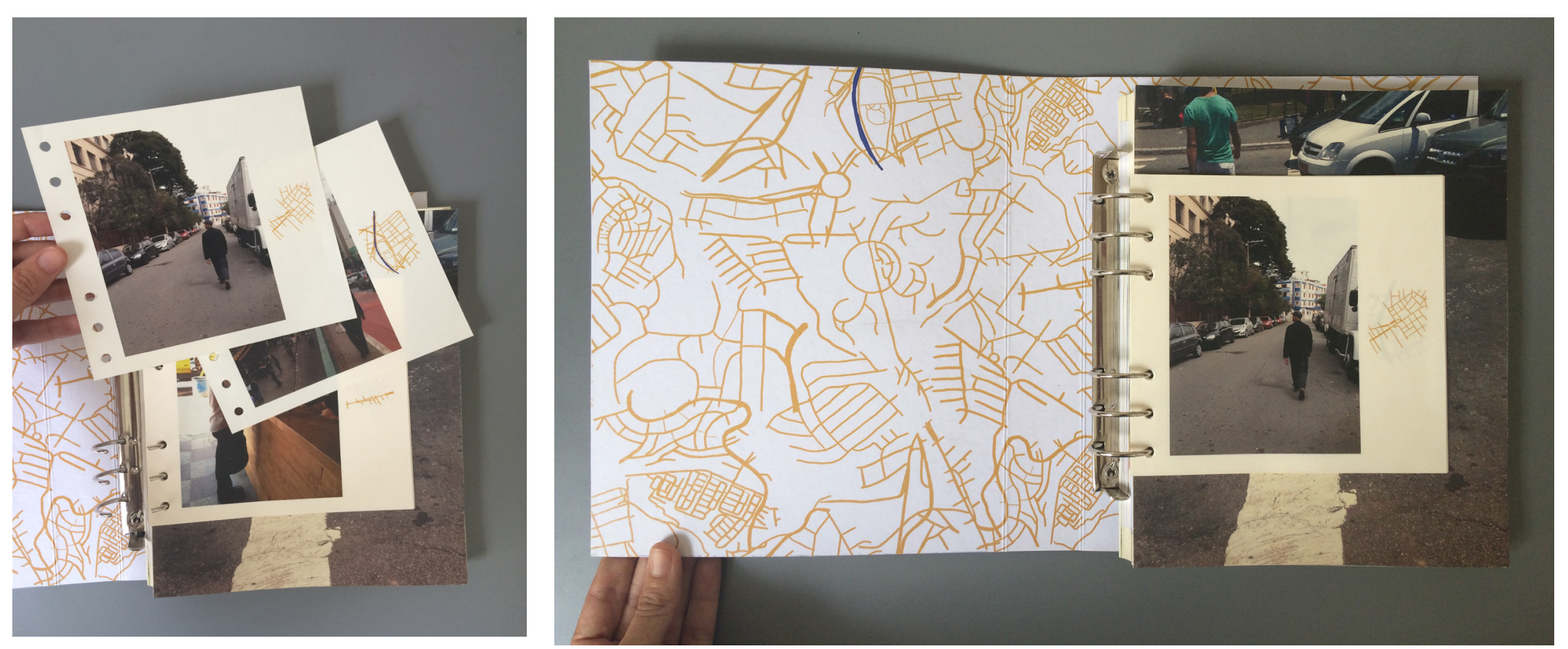

Figura 55 - Folhas internas de Cidade Passo 

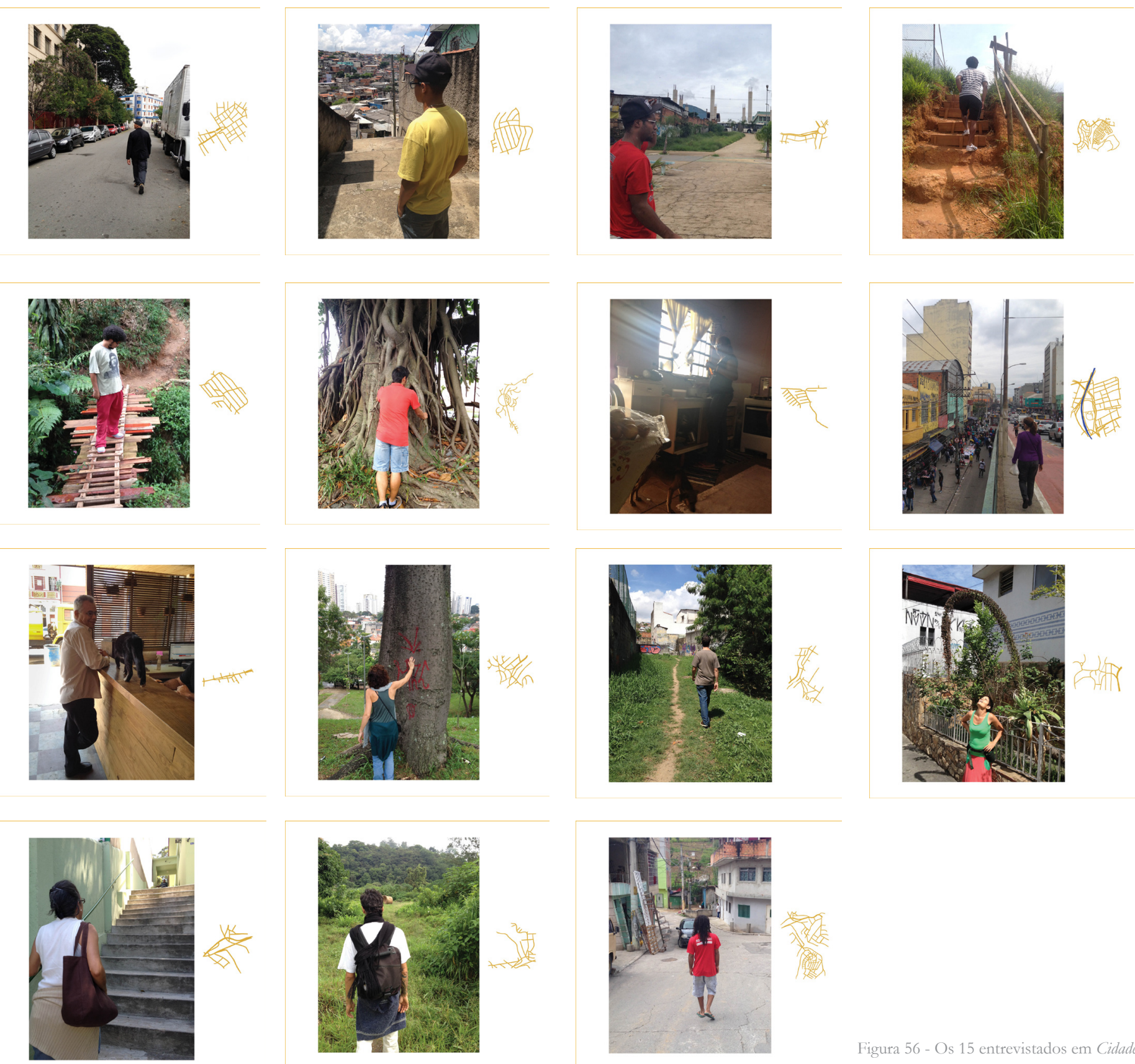

Figura 56 - Os 15 entrevistados em Cidade Passo 

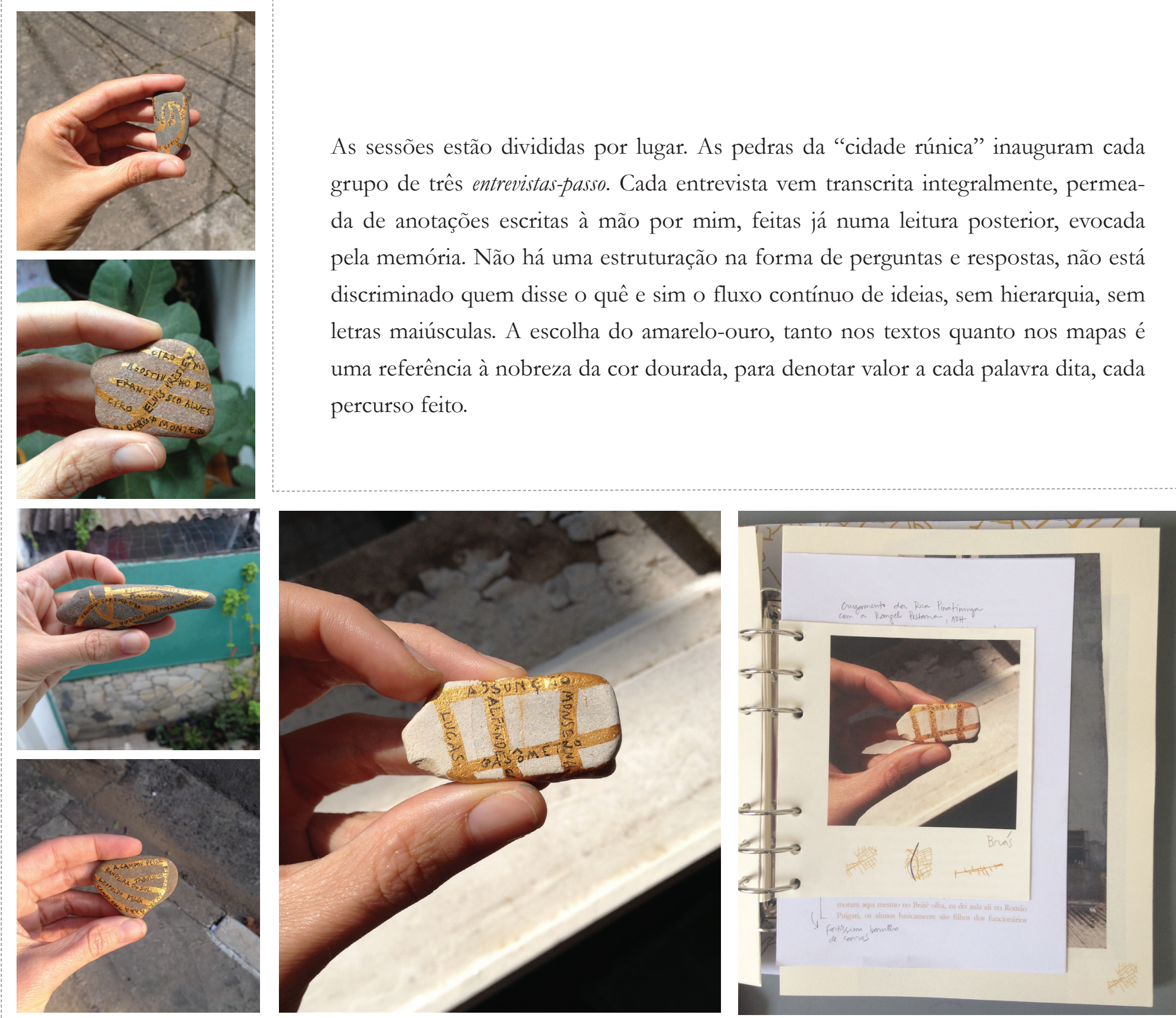

As sessões estão divididas por lugar. As pedras da "cidade rúnica" inauguram cada grupo de três entrevistas-passo. Cada entrevista vem transcrita integralmente, permeada de anotações escritas à mão por mim, feitas já numa leitura posterior, evocada pela memória. Não há uma estruturação na forma de perguntas e respostas, não está discriminado quem disse o quê e sim o fluxo contínuo de ideias, sem hierarquia, sem letras maiúsculas. A escolha do amarelo-ouro, tanto nos textos quanto nos mapas é uma referência à nobreza da cor dourada, para denotar valor a cada palavra dita, cada percurso feito.

Figura 57 - Imagens que abrem as sessões de Cidade Passo 

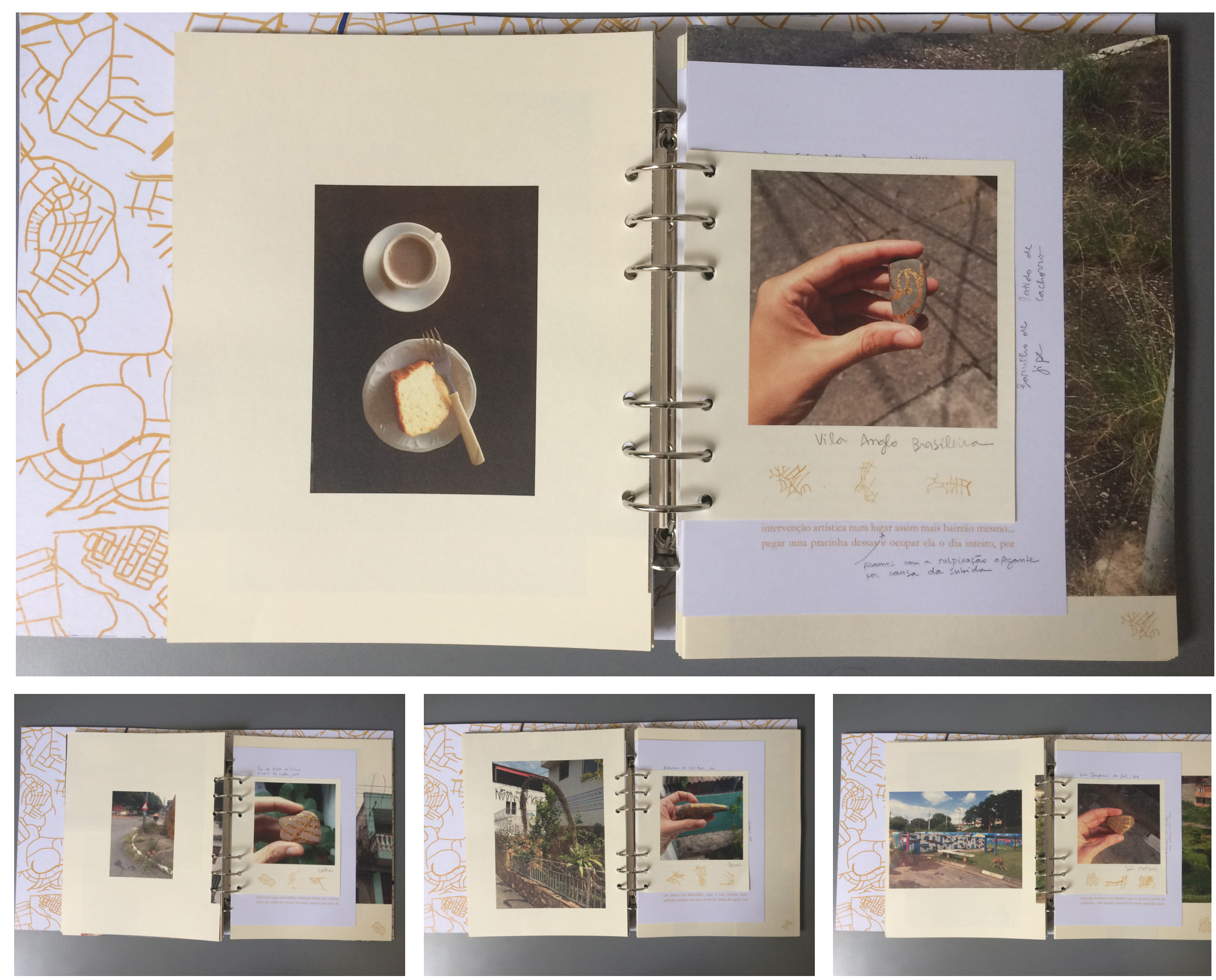

Figura 58 - Imagens que abrem as sessões de Cidade Passo 


$$
\text { हैiff 镂 }
$$
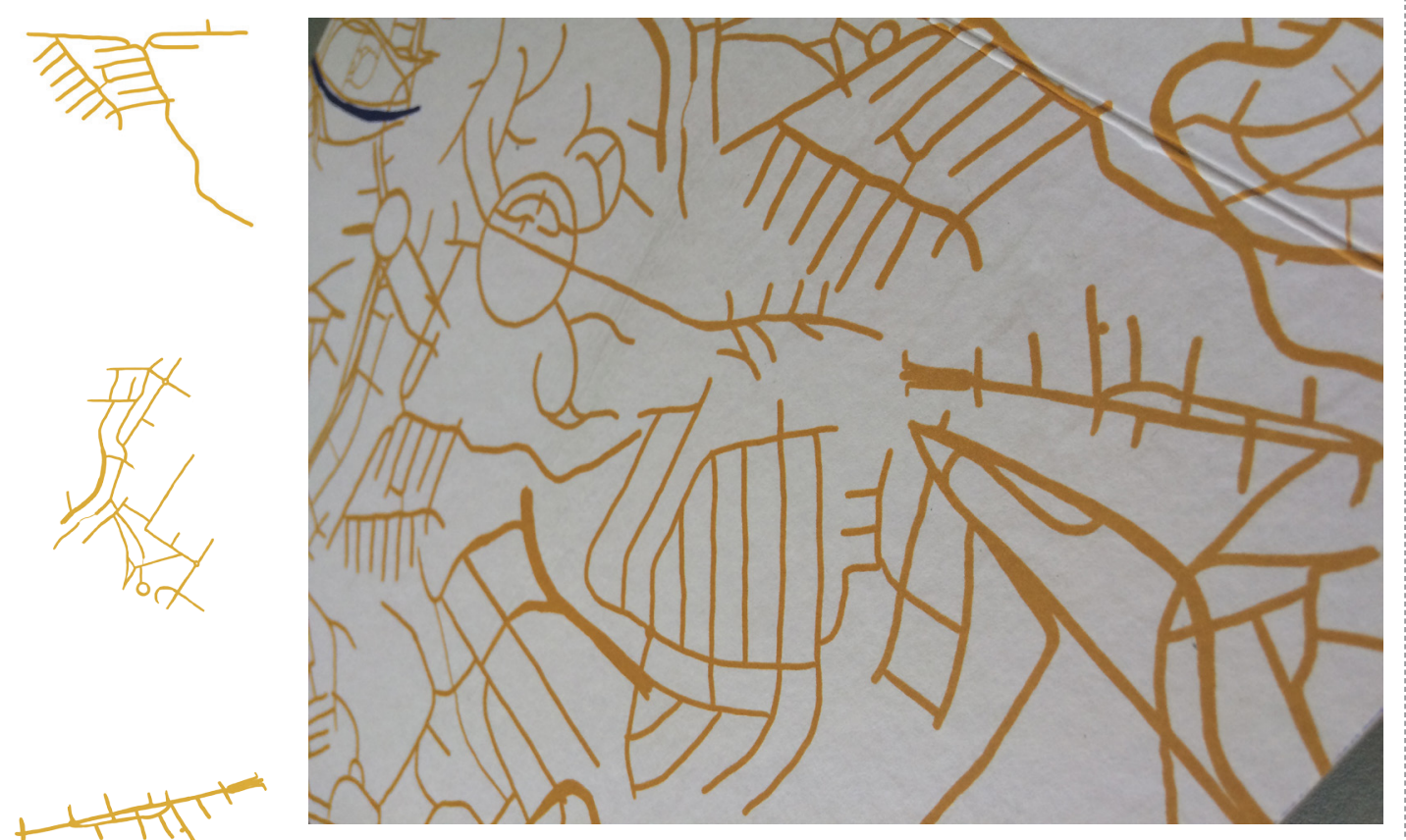

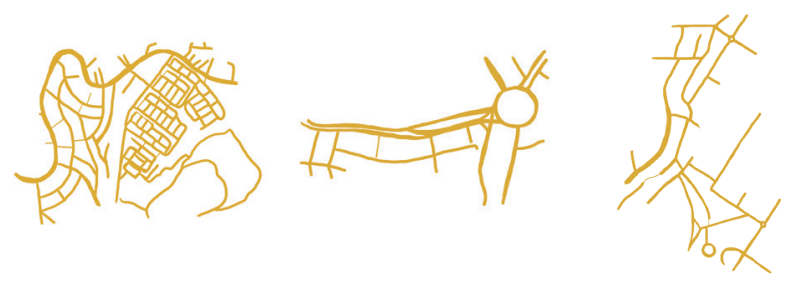
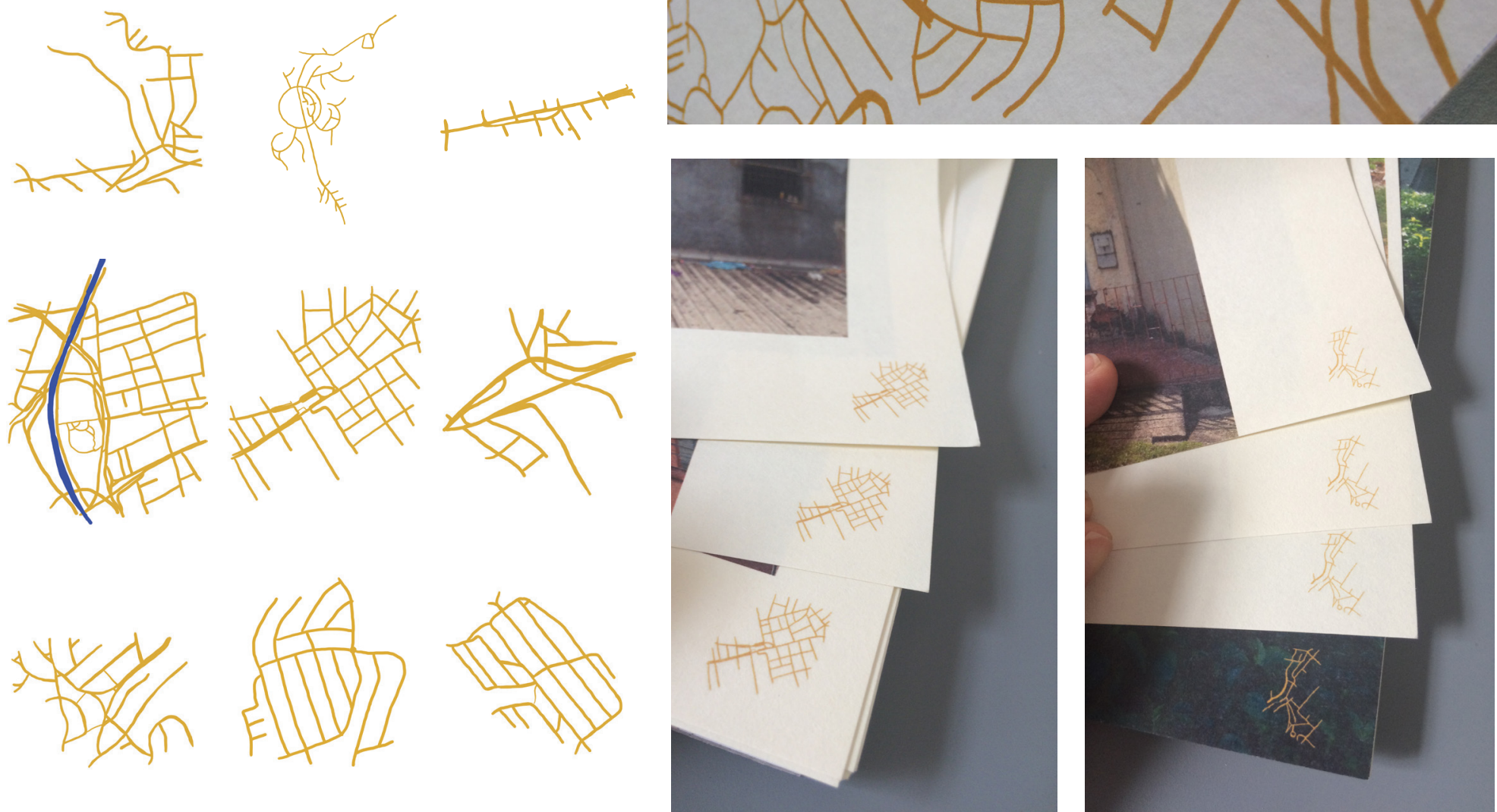

Figura 59 - Linhas dos percursos de Cidade Passo 


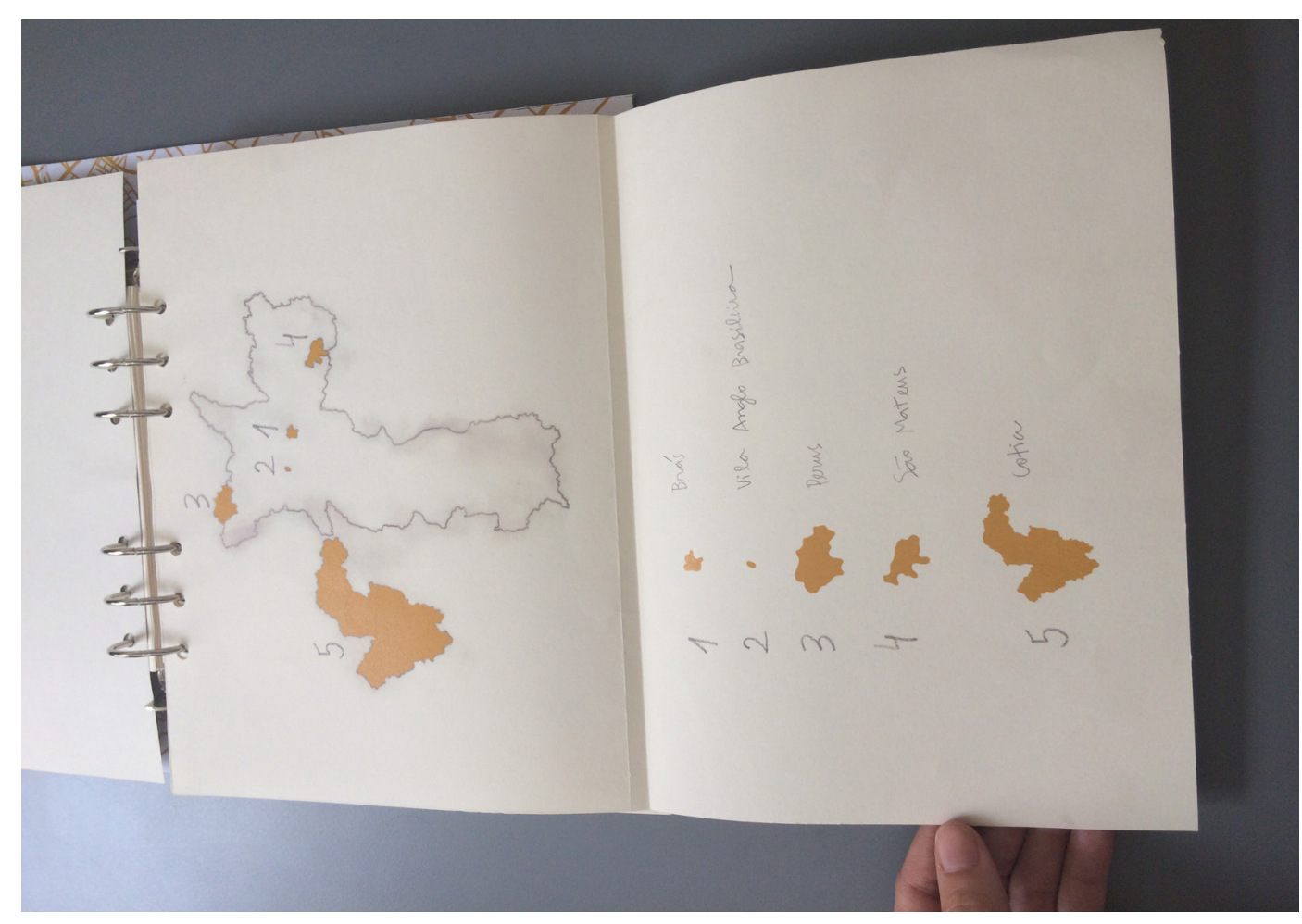

Figura 60 - Mapa do livro Cidade Passo

Ao invés de numeracão de páginas, escolhi identificar as folhas com o ícone do percurso a que fazem parte. O antropólogo britânico Tim Ingold, em sua formulação do que chama de "antropologia da linha", explica:

O que andar, acenar, observar, cantar, contar histórias, desenhar e escrever têm em comum? A resposta é que todas estas ações procedem ao longo de linhas de um tipo ou de outro. [...] Como criaturas que andam, falam e gesticulam os seres humanos geram linhas aonde quer que vão (INGOLD, 2007, p 1, tradução nossa).
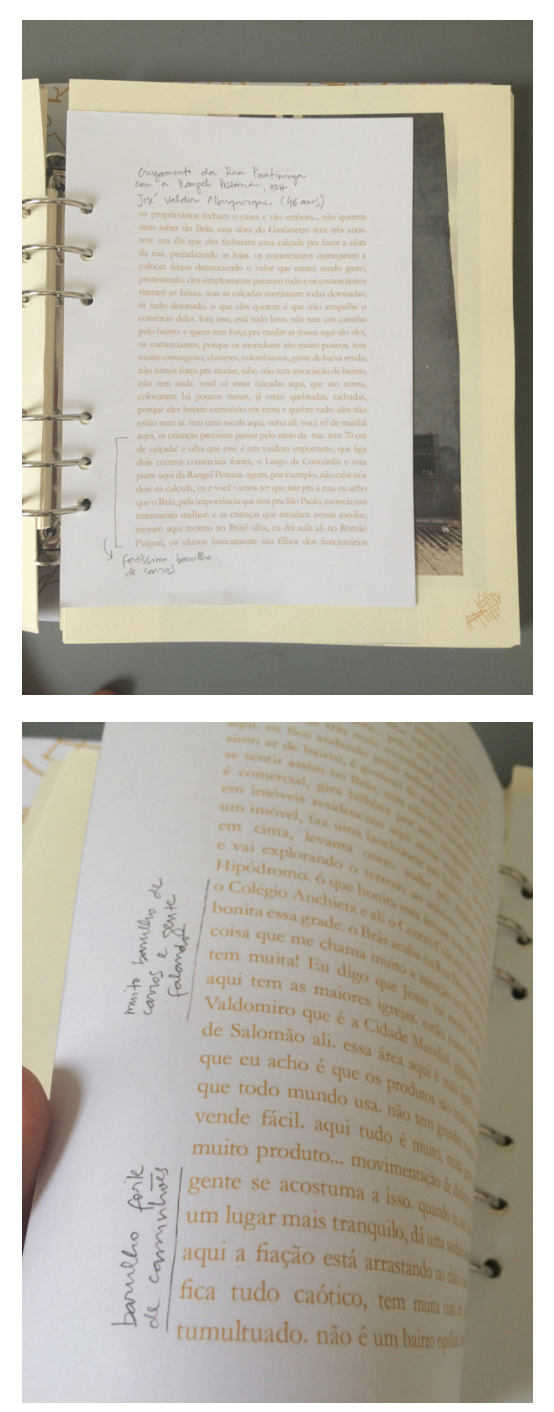

Figura 61 - Entrevistas transcritas em Cidade Passo

Os trajetos percorridos inscrevem linhas no espaço urbano, assim como as conversas, que foram sendo "puxadas" pelas memórias afetivas evocadas pelos caminhos. Essas linhas formam figuras e estas identificam, graficamente, os grupos de páginas, bem como ilustram a composição na guarda do livro. 
Foram tiradas inúmeras fotografias, a maioria às cegas, durante os percursos, ou seja, sem preparar demais os enquadramentos, buscar uma estetização " $\mathrm{X}$ ”, ou nenhum tipo de uniformização das mesmas. O intuito era registrar o que chamou minha atenção, mostrar o que foi visto, buscando criar, inicialmente, imagens de cunho referencial. Seu caráter de "objeto útil”, de registro, tão caro à pesquisa etnográfica, desdobrou-se, e a dimensão sensível, estética das fotos foi sendo descoberta no momento posterior, de edição.

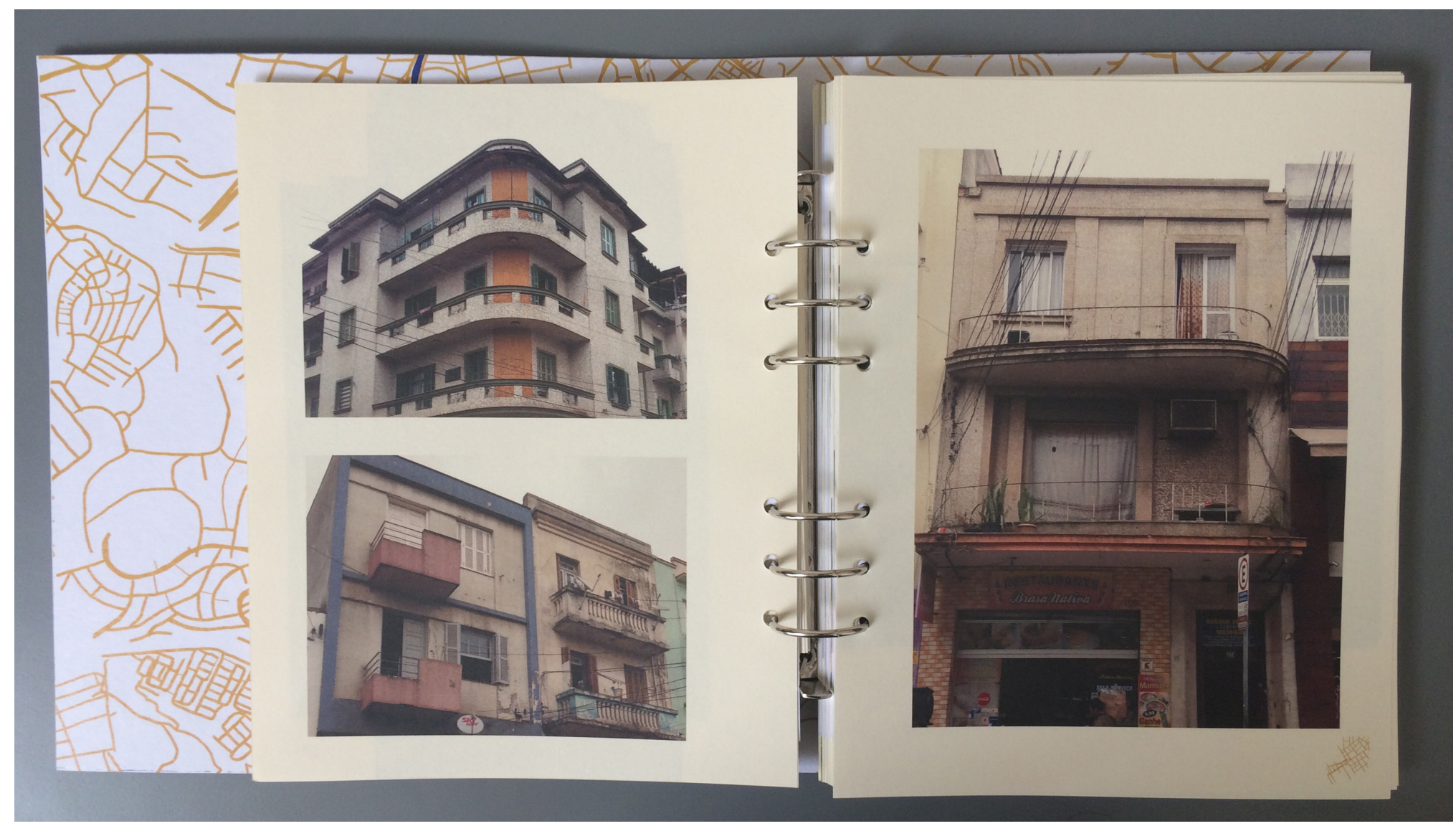

Figura 62 - Fotografias do Brás em Cidade Passo 


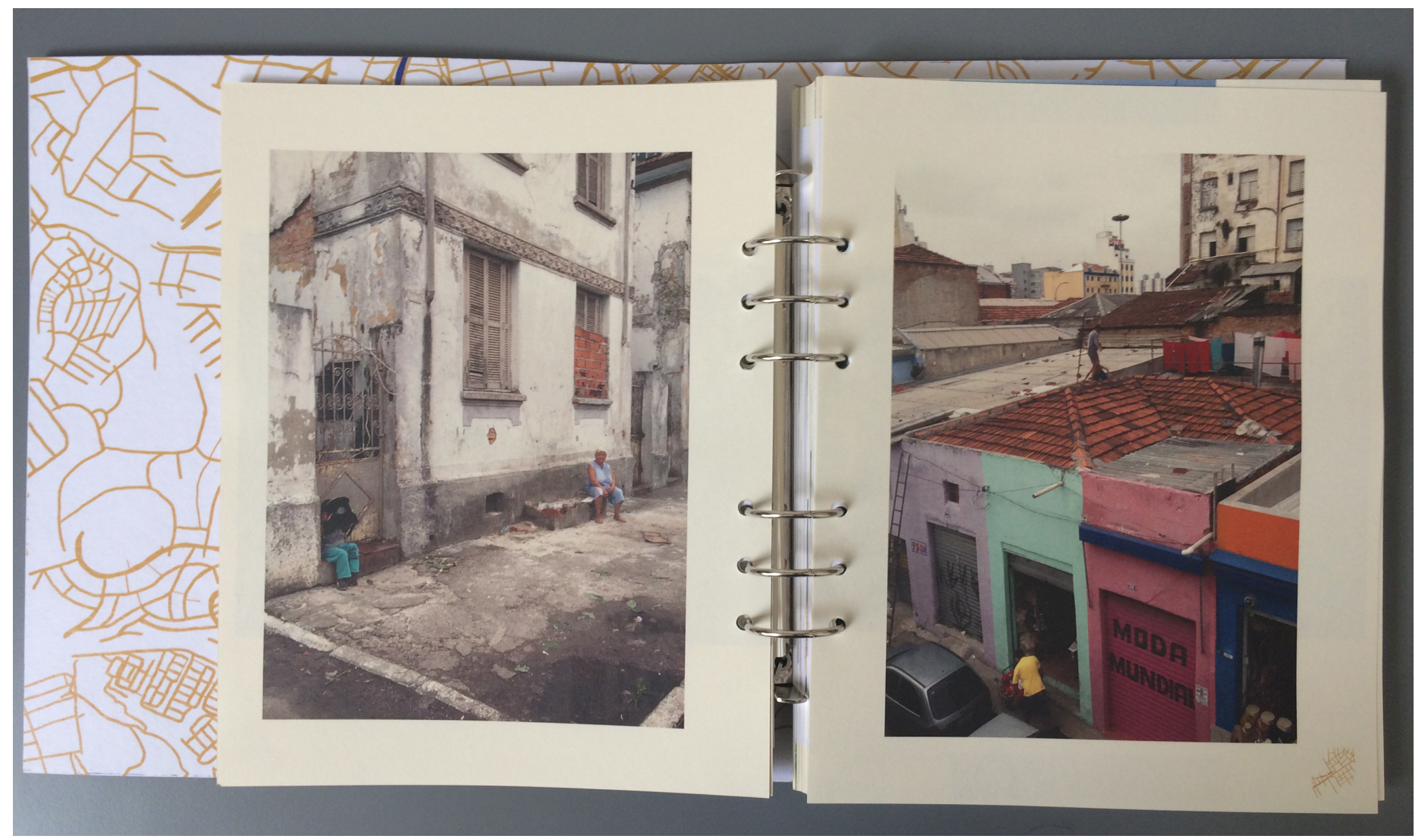

Figura 63 - Fotografias do Brás em Cidade Passo 

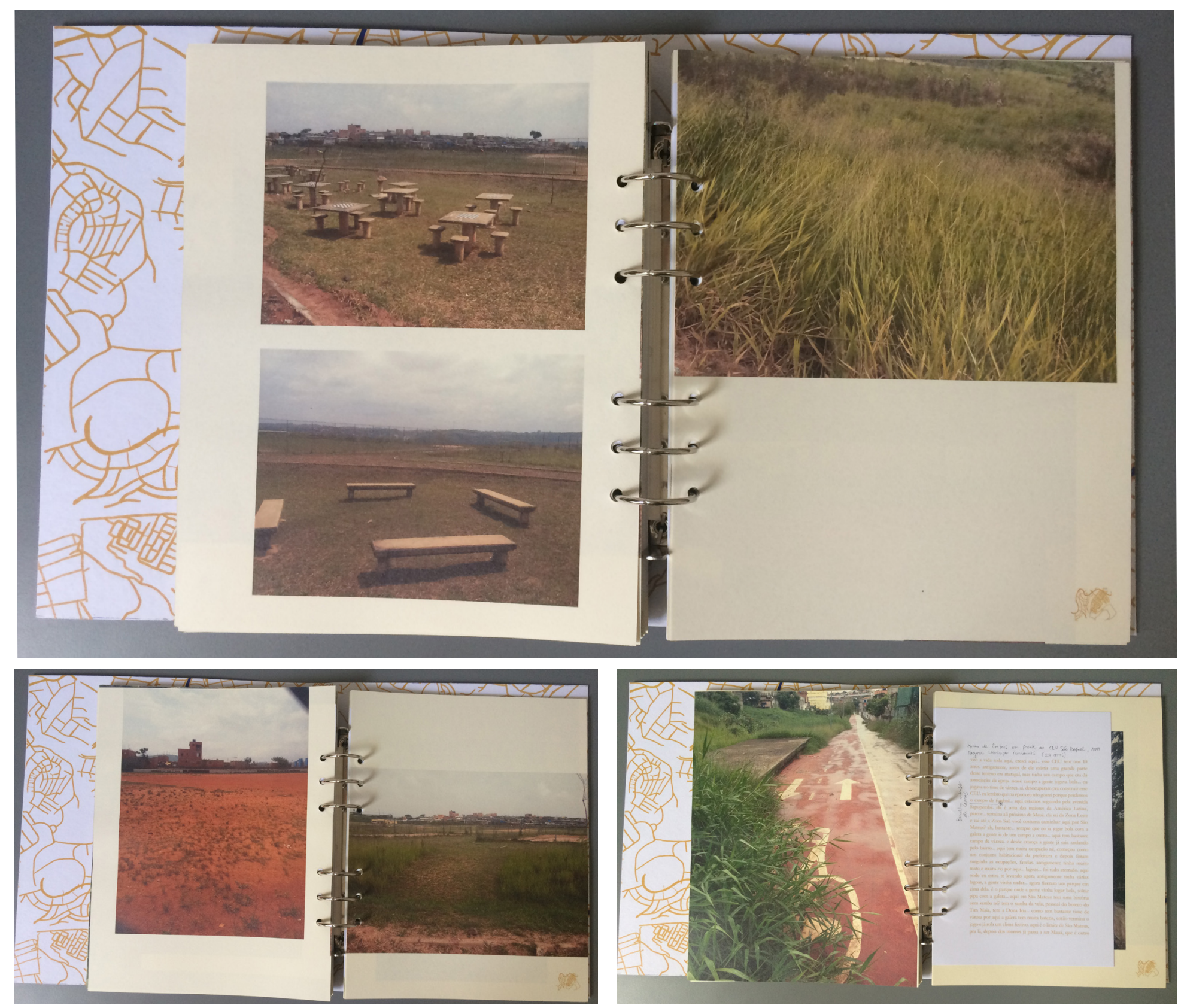

Figura 64 - Fotografias de São Mateus em Cidade Passo 

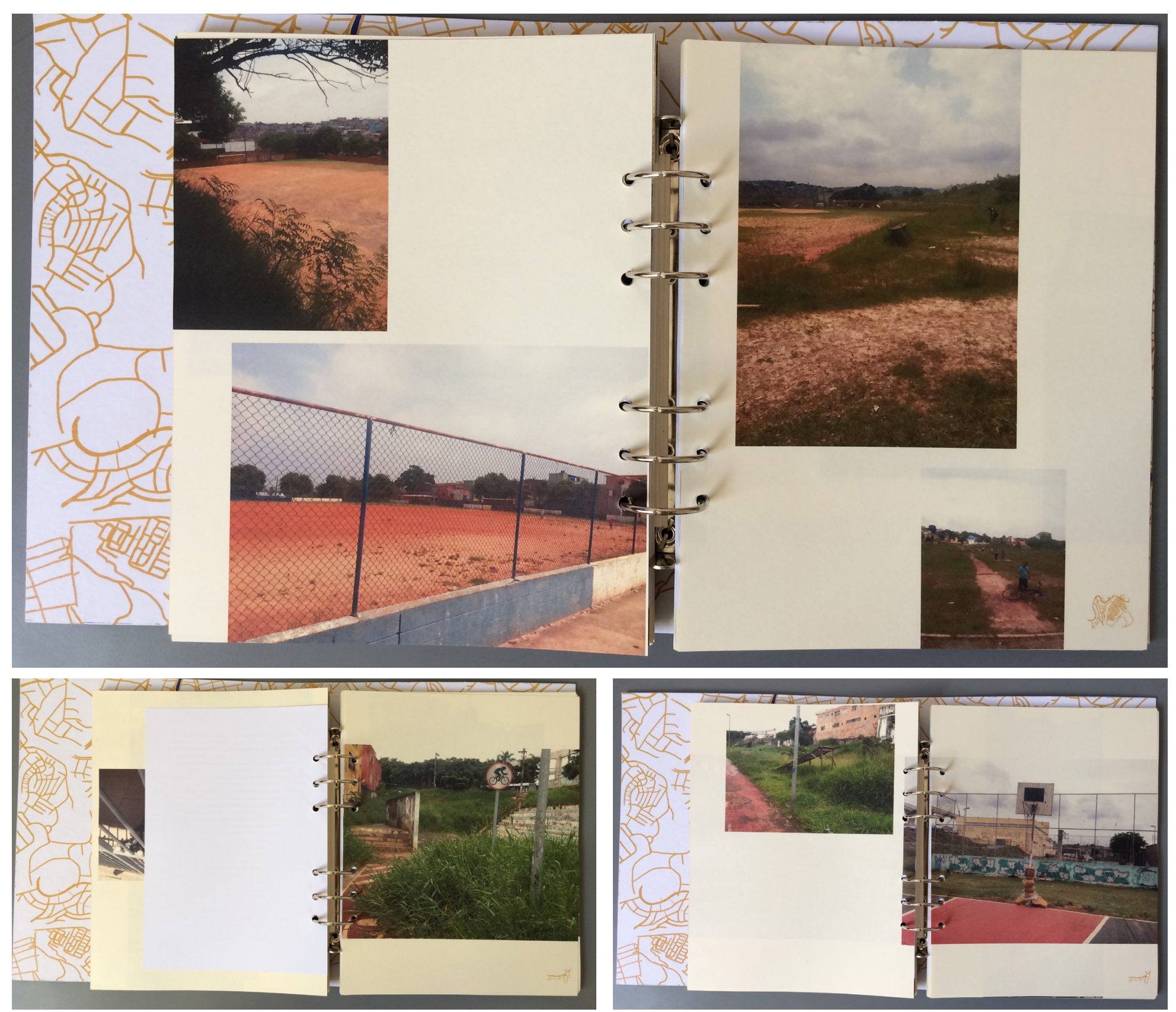

Figura 65 - Fotografias de São Mateus em Cidade Passo 

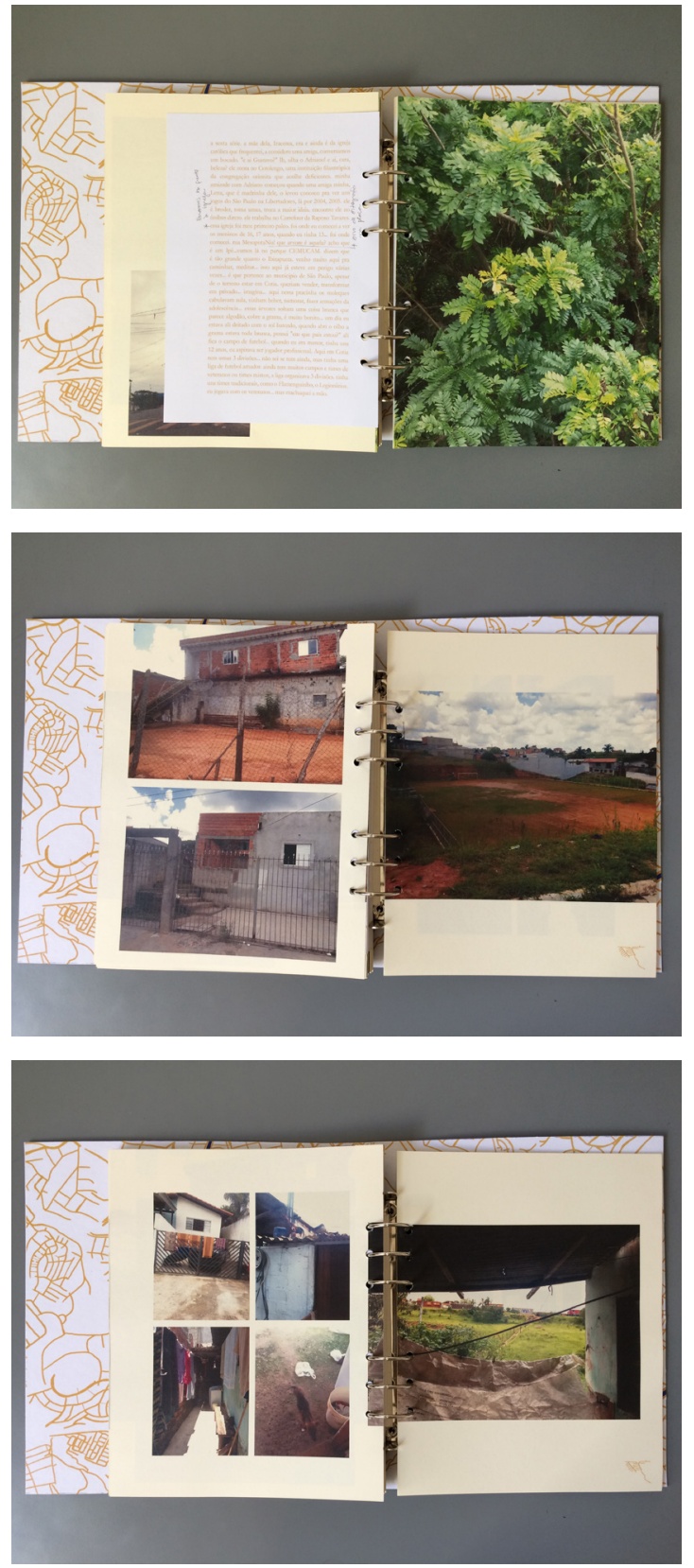

Figura 66 - Fotografias de Cotia em Cidade Passo
Daniela Mendes Cidade, em seu estudo "A cidade revelada - A fotografia como prática de assimilação da arquitetura" defende que a "fotografia de arquitetura" ou a "fotografia urbana", inserida na linguagem das artes visuais, pode vir a ser um instrumento potente de reflexão sobre a arquitetura e os fenômenos urbanos, uma vez que possibilitam uma linguagem direta e ao mesmo tempo subjetiva sobre as transformações do espaço (CIDADE, 2002, p. 11).

"O estudo sobre a cidade requer a contribuição de outras áreas do conhecimento como psicologia, geografia e história. No seio desta interdisciplinaridade devemos acrescentar a arte, principalmente a fotografia, como uma linguagem de expressão capaz de revelar os aspectos da cidade que passam desapercebidos por muitas pessoas, e que, entretanto, apresentam um caráter subjetivo indispensável para o estudo da cidade na sua totalidade" (ibid, p. 23 e 24).

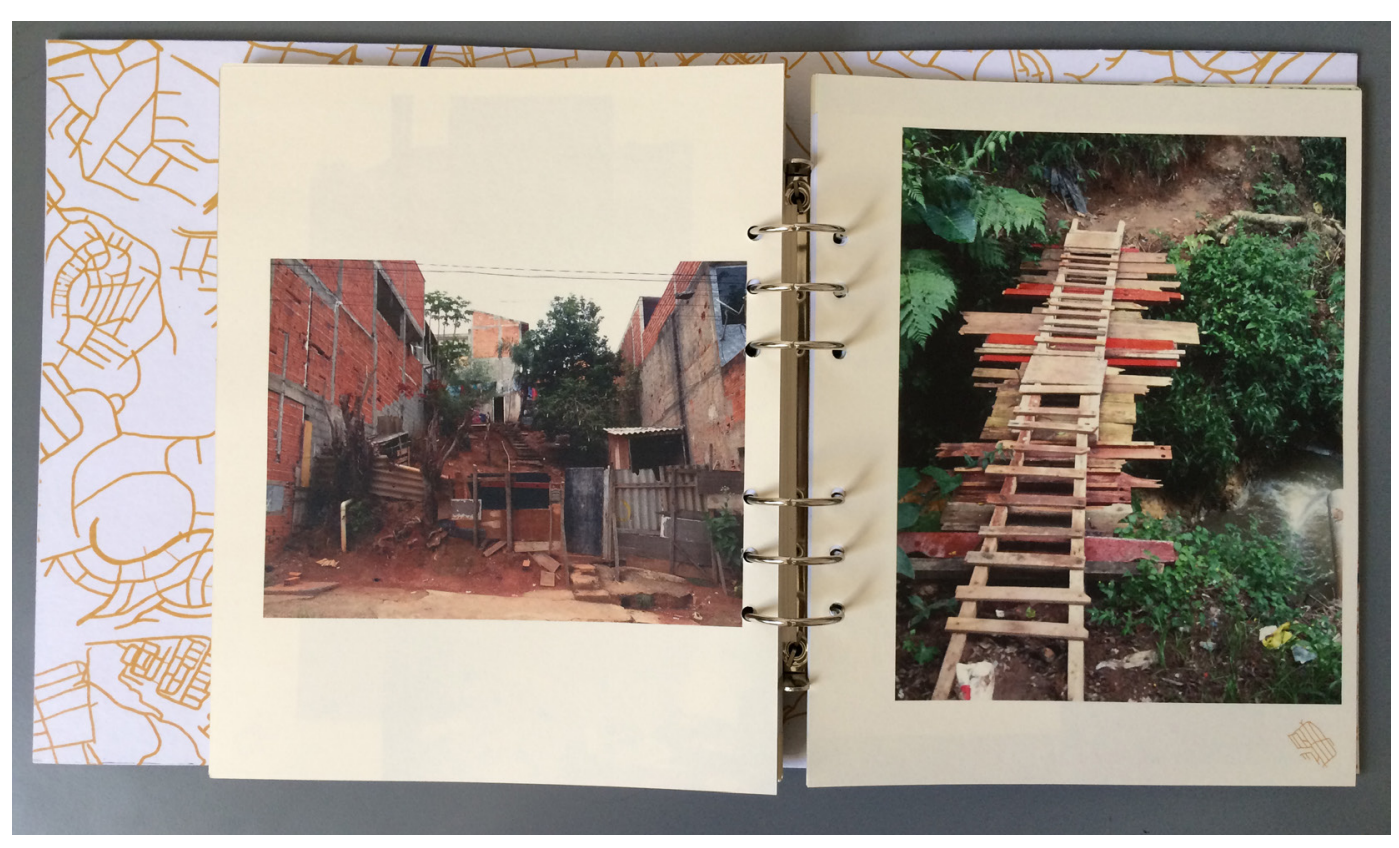



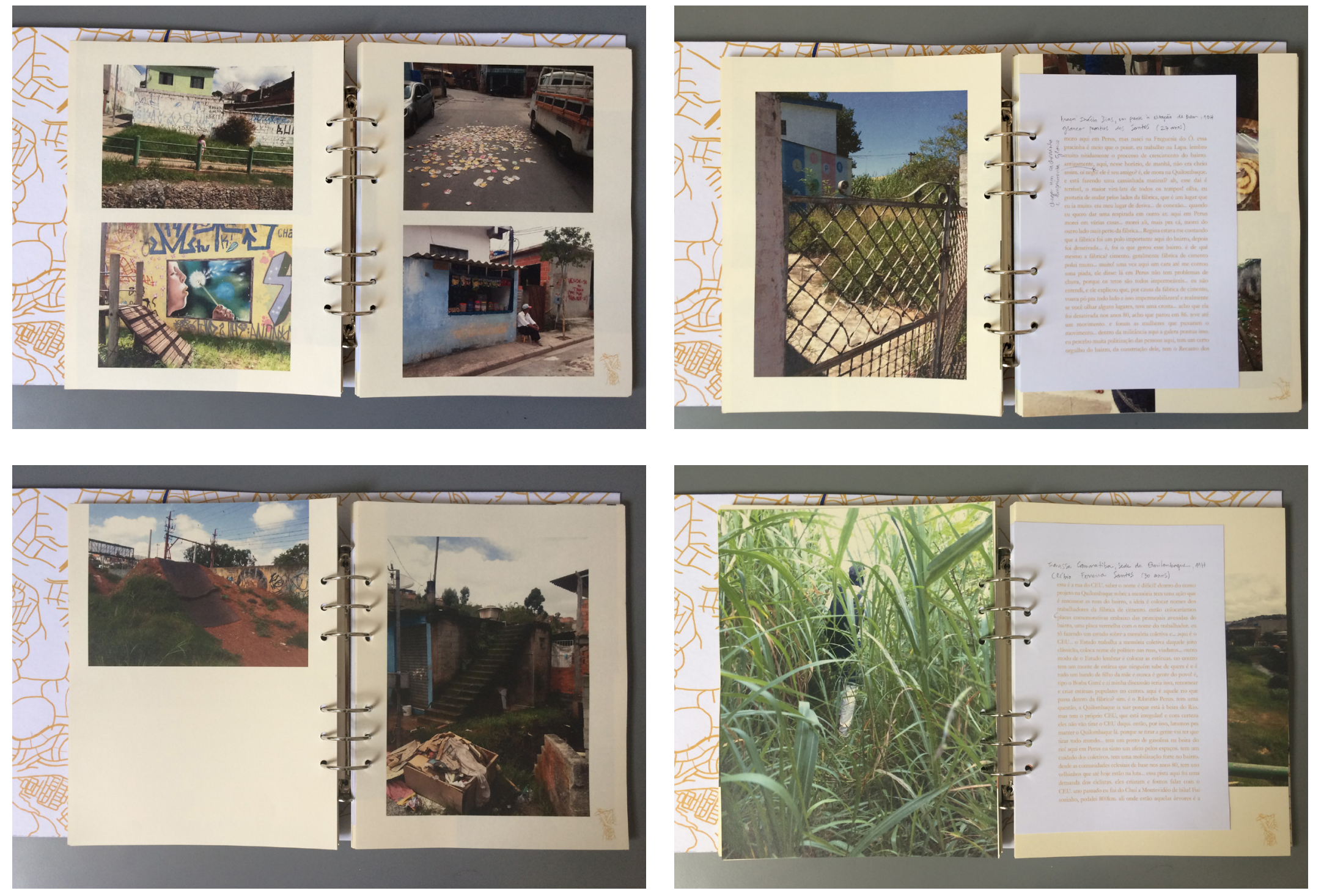

Figura 67 - Fotografias de Perus em Cidade Passo 


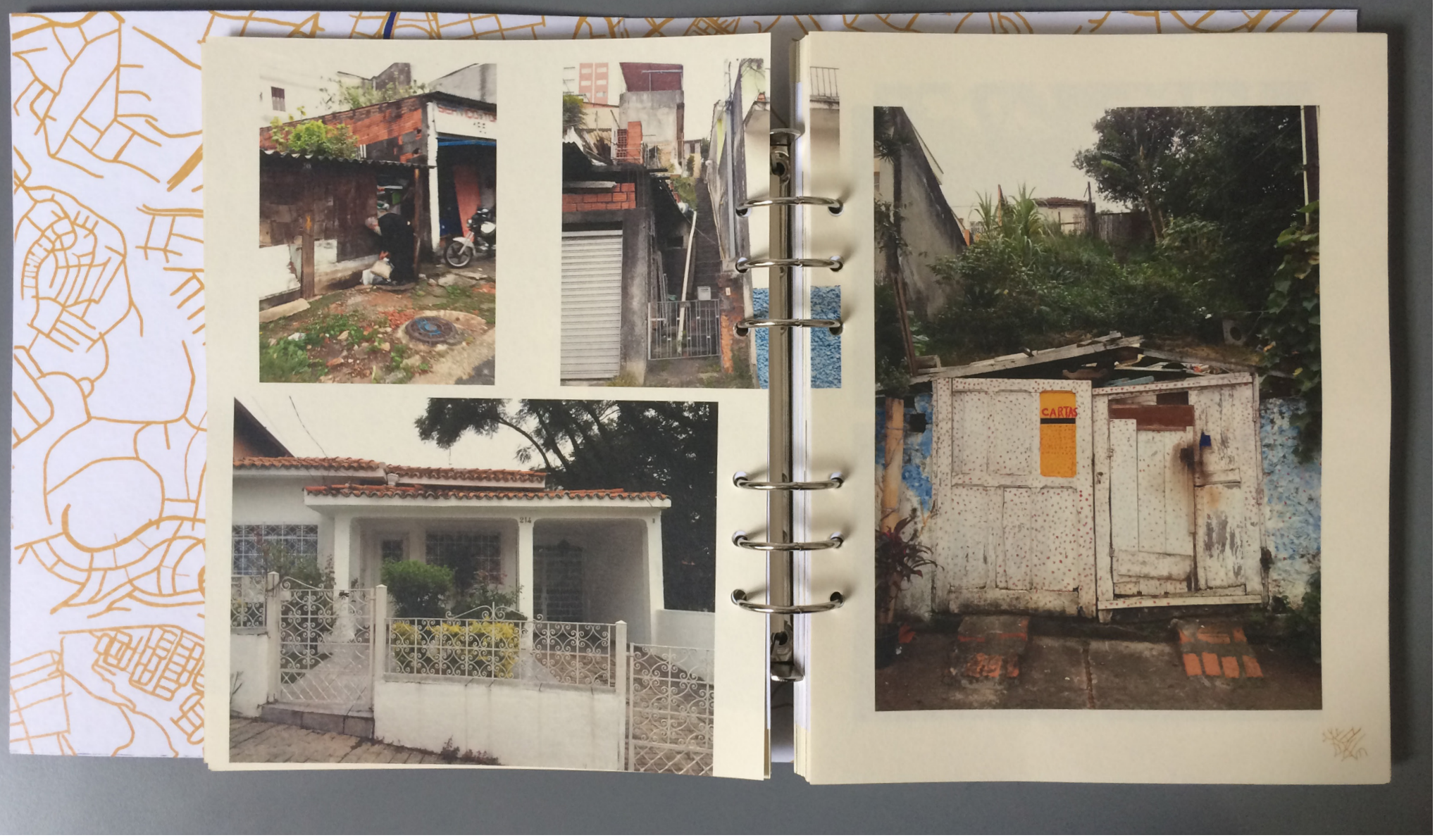

Figura 68 - Fotografias da Vila Anglo Brasileira em Cidade Passo 


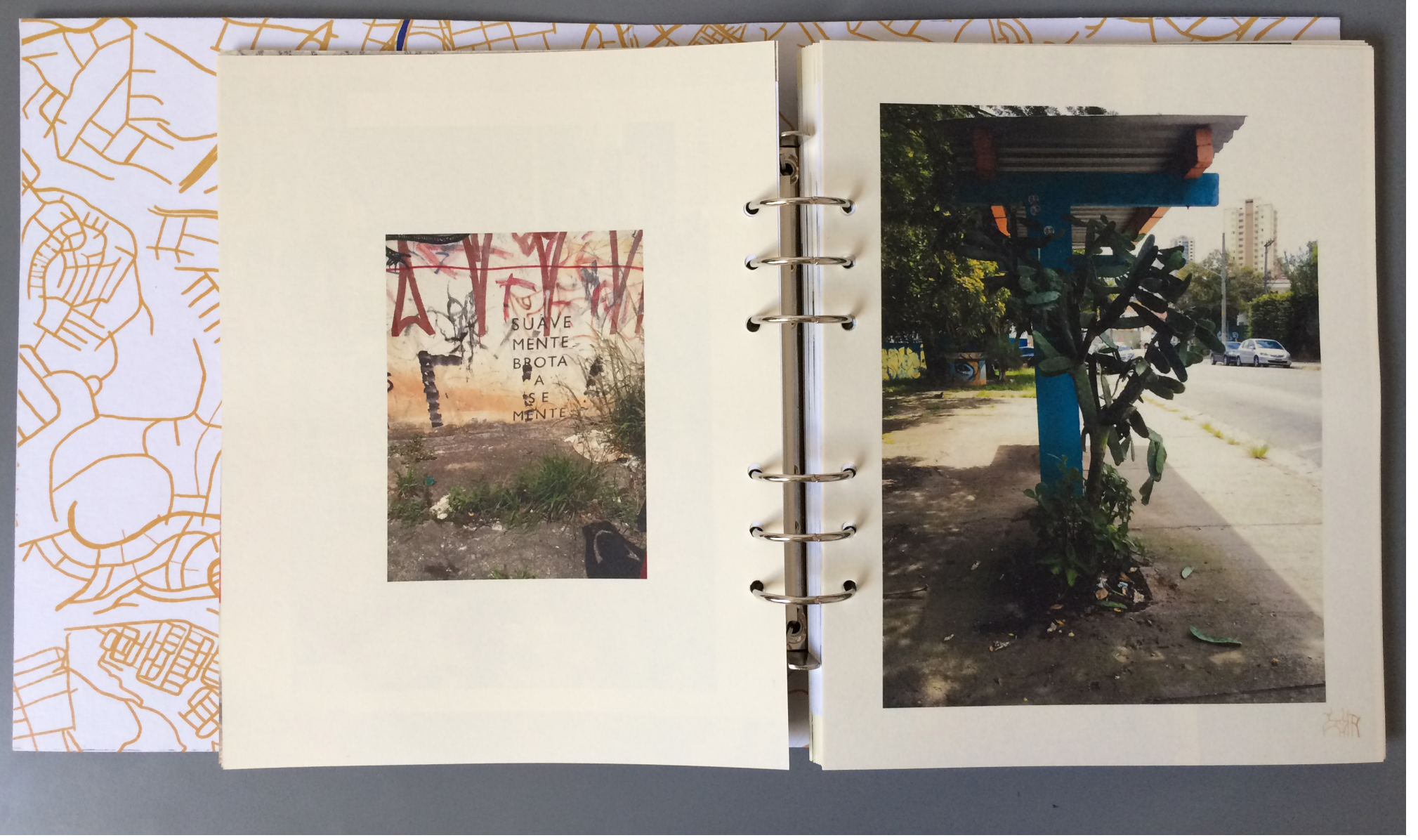

Figura 69 - Fotografias da Vila Anglo Brasileira em Cidade Passo 


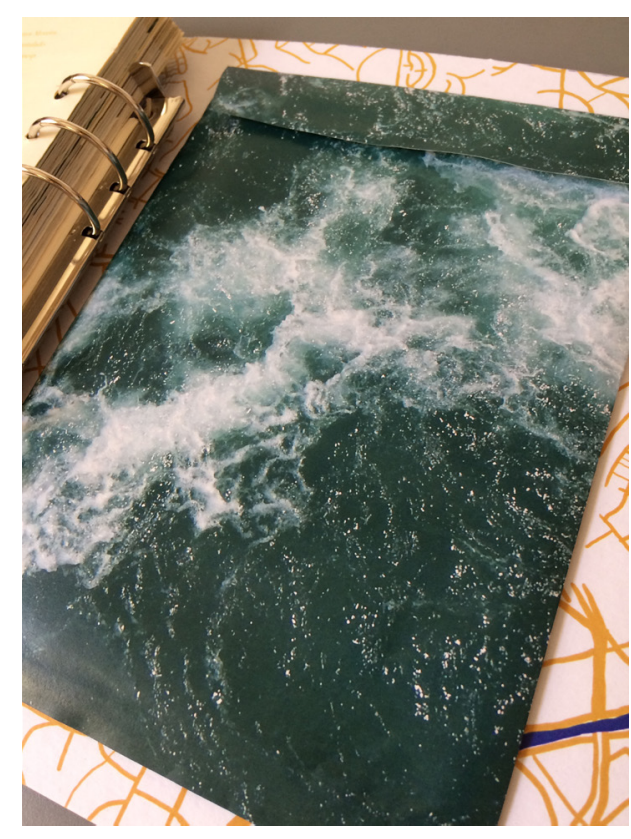

Figura 70 - Envelope em Cidade Passo
Fechando a narrativa de Cidade Passo, um envelope com estampa de mar revolto guarda uma tira de papel de 1,80m de altura. Nesse espaço em branco, 77 carimbos feitos a partir das fotografias e falas vistas nas páginas anteriores criam composições aleatórias, únicas em cada volume. Esse desdobramento surgiu de um desejo de desconstruir a experiência em narrativas outras, abertas, ficções possíveis. Ampliar a ideia de deriva gráfica, dando uma nova possibilidade de participação ao leitor. Fazer com que o vivido não acabasse no meu relato, mas tivesse continuidade de maneira lúdica no imaginário de quem tenha contato com o livro.

Roland Barthes em A câmara clara, diz sobre um dos aspectos essenciais da fotografia: "O que a fotografia reproduz ao infinito só ocorre uma vez: ela repete mecanicamente o que nunca mais poderá repetir-se existencialmente” (BARTHES, 1984, p. 13).

O evento eternizado pela fotografia é o rastro de uma presença que se encontra em um tempo e espaço específicos. Ela pertence a um contexto, uma época. Os carimbos descontextualizam, fragmentam, recriam a imagem captada pela câmera, que perde a "raiz", se aparta se sua matriz e passa a ser forma livre. Combinadas umas com as outras, geram composições que formam novas narrativas e evocam novos sentidos. A memória, deste modo, se confunde com imaginação.

Memória e imaginação tem como traço comum a presença do ausente e como traço diferencial, de um lado, a suspensão de toda posição de realidade e a visão de um irreal e do outro, a posição de um real anterior (RICOEUR, 2007, p. 61). 


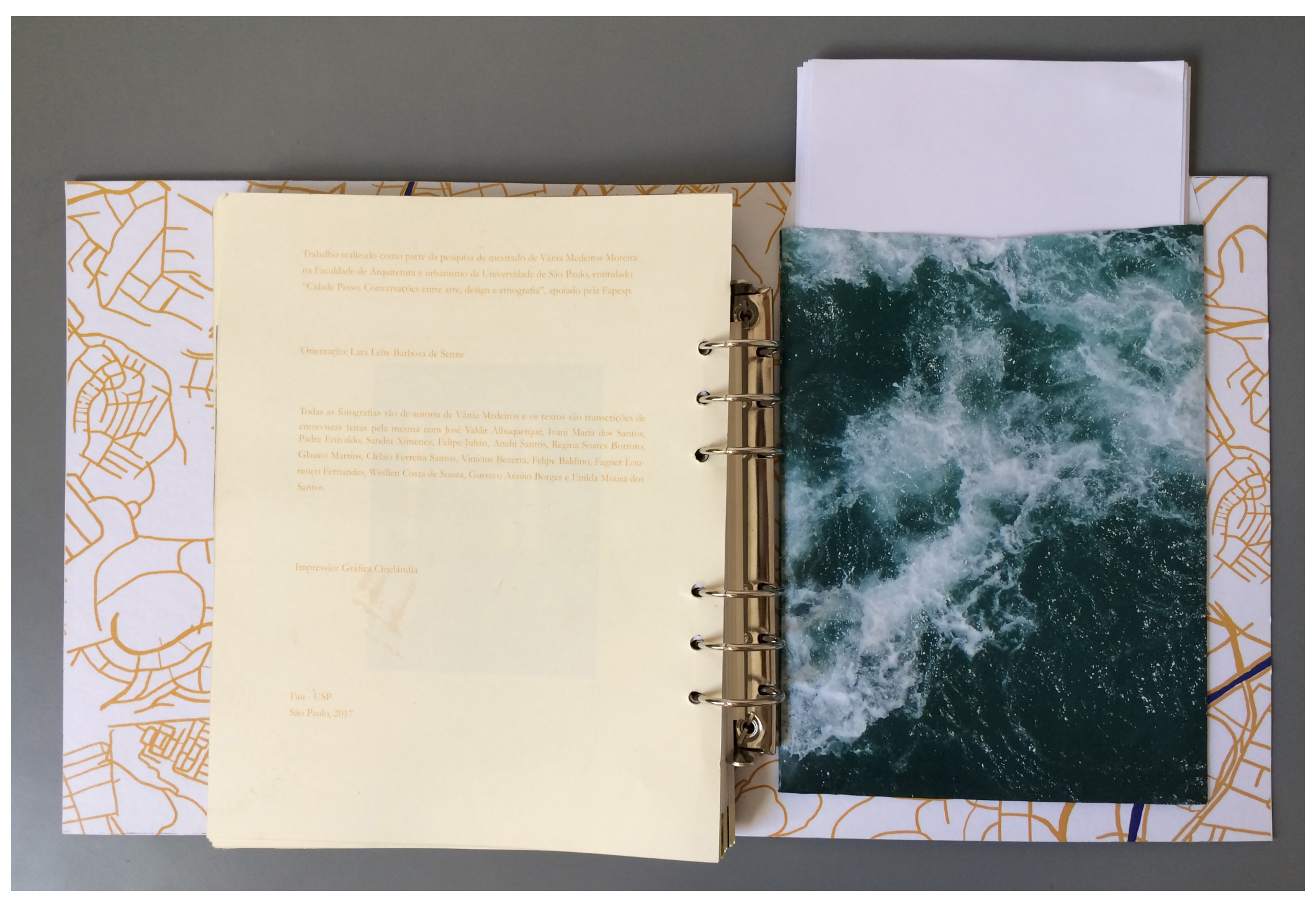

Figura 71 - Envelope em Cidade Passo 


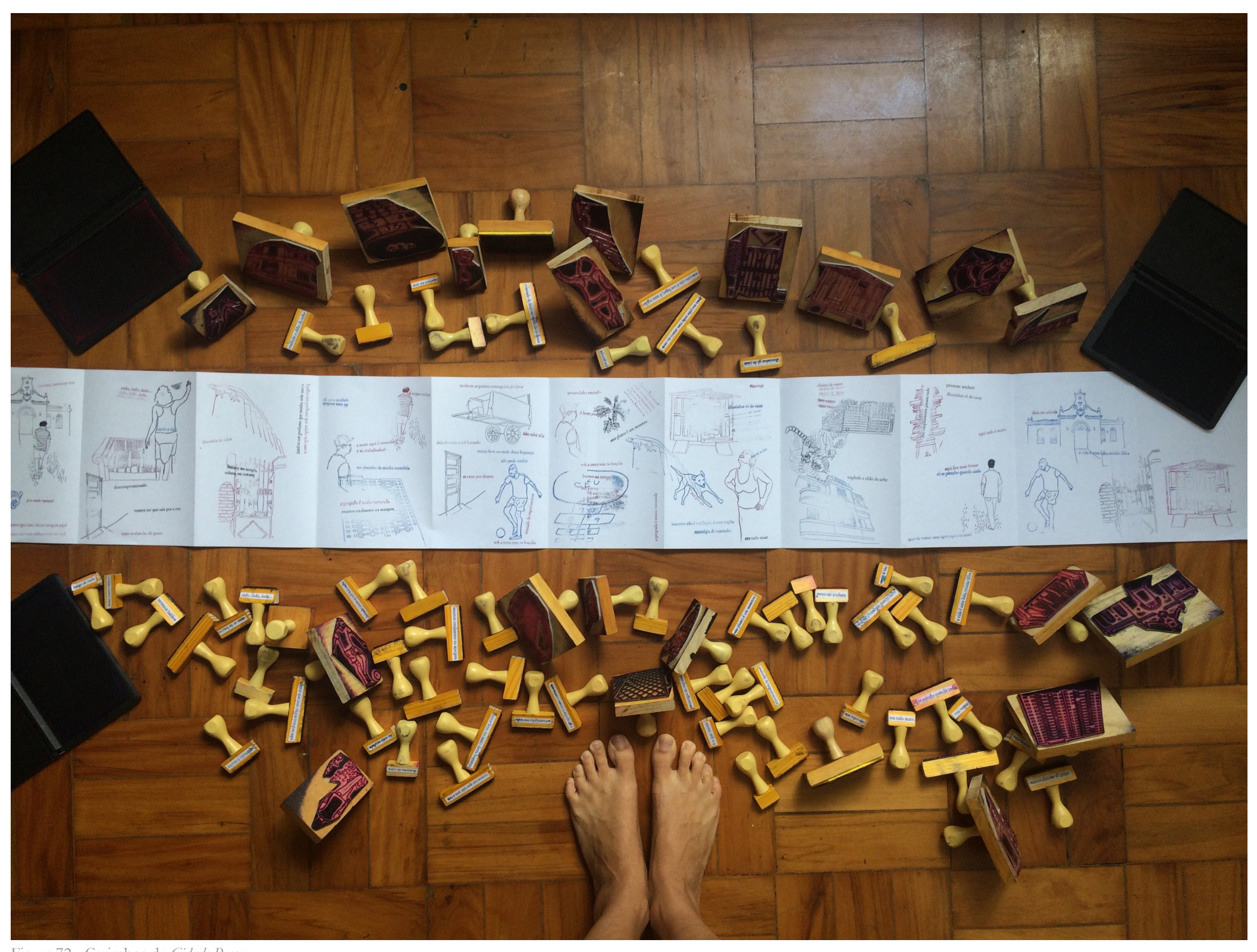

Figura 72 - Carimbos de Cidade Passo 

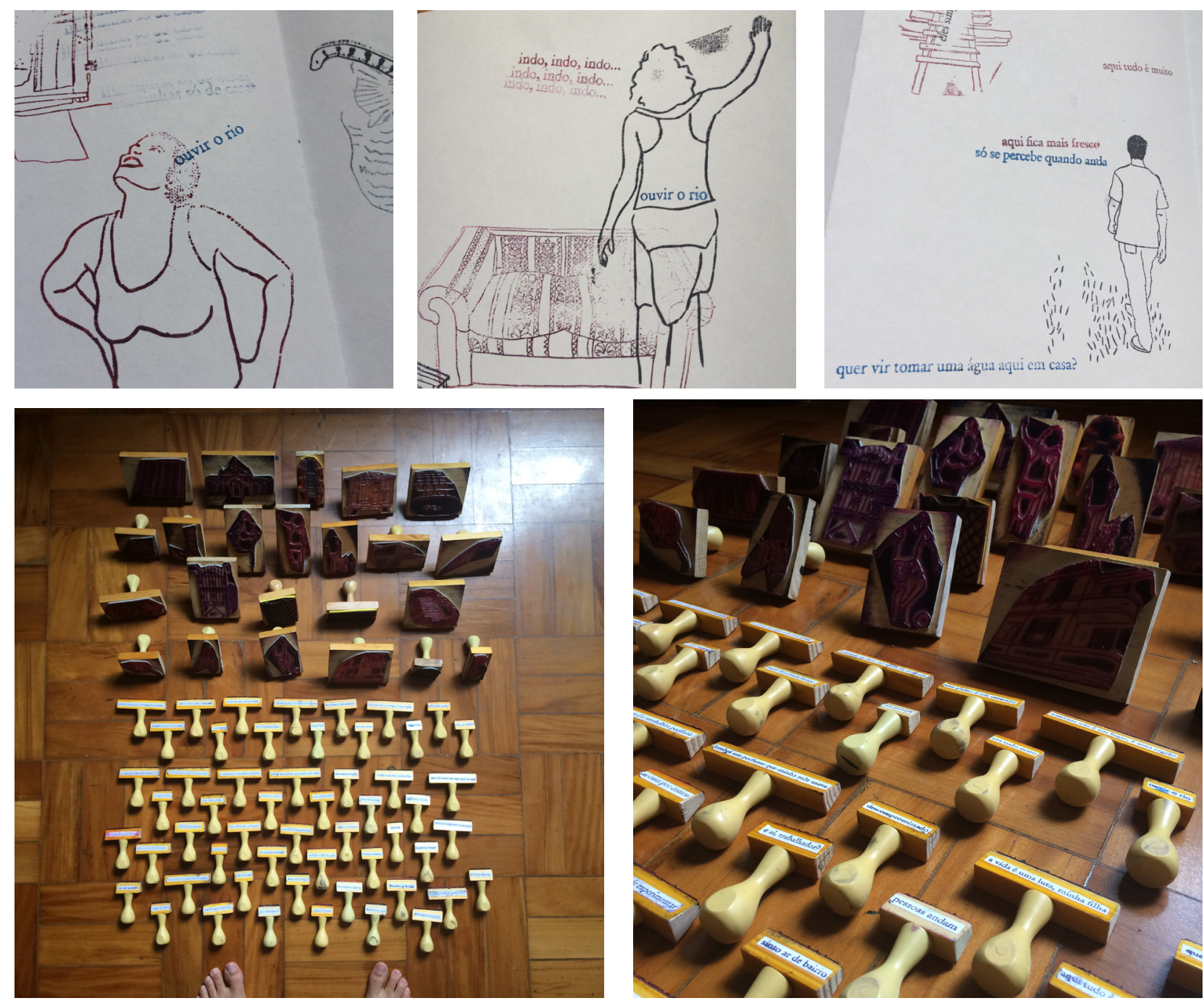

Figura 73 - Carimbos de Cidade Passo

Existe a idéia de que o próprio leitor/ usuário/ ativador possa manusear esses carimbos, fazendo ele mesmo sua própria deriva, a partir de sua própria ação sobre o papel. Isto enquanto possibilidade projetual deverá ser desenvolvido em um posterior desdobramento da pesquisa. 


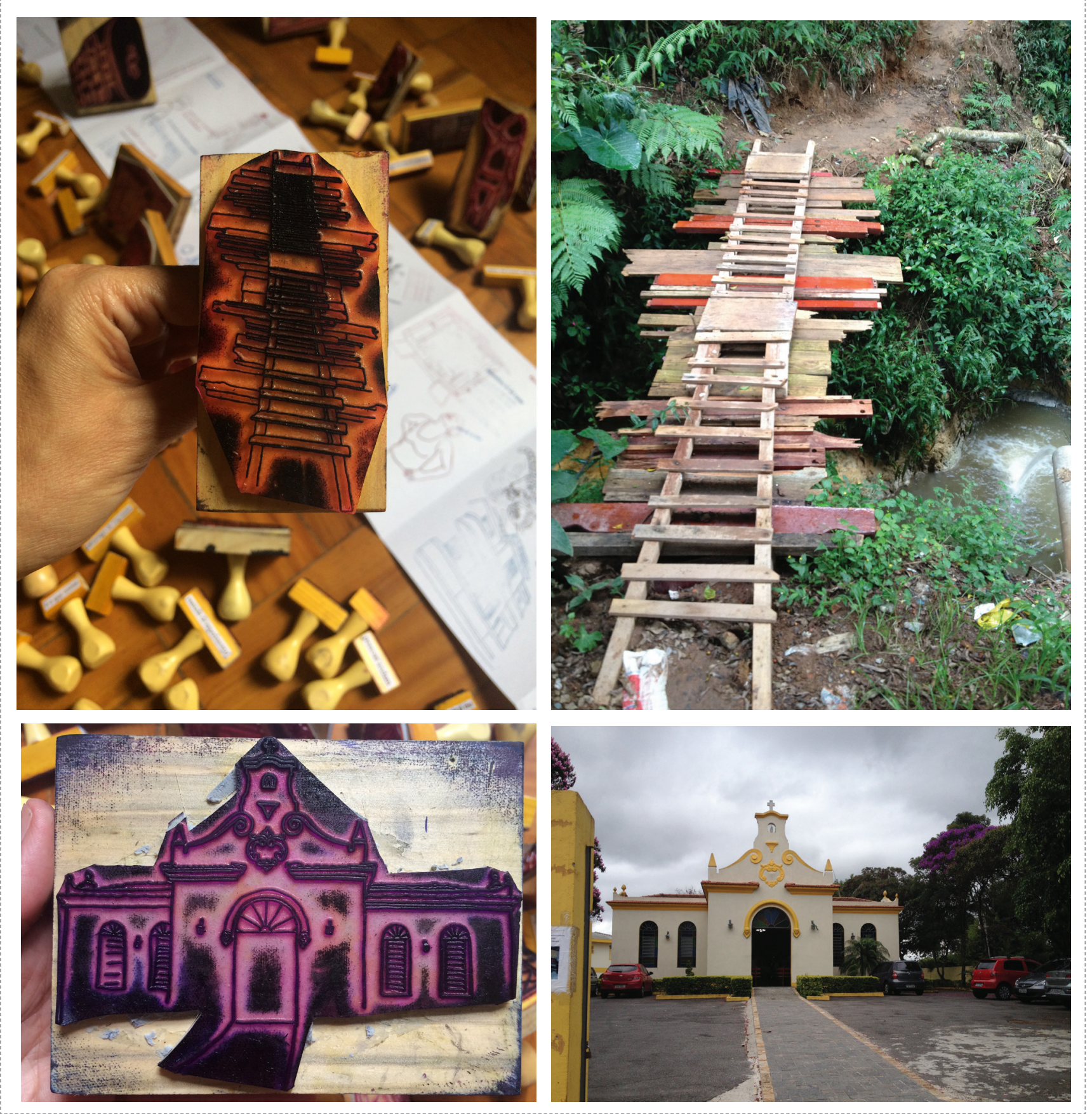

Figura 74 - Carimbos de Cidade Passo 

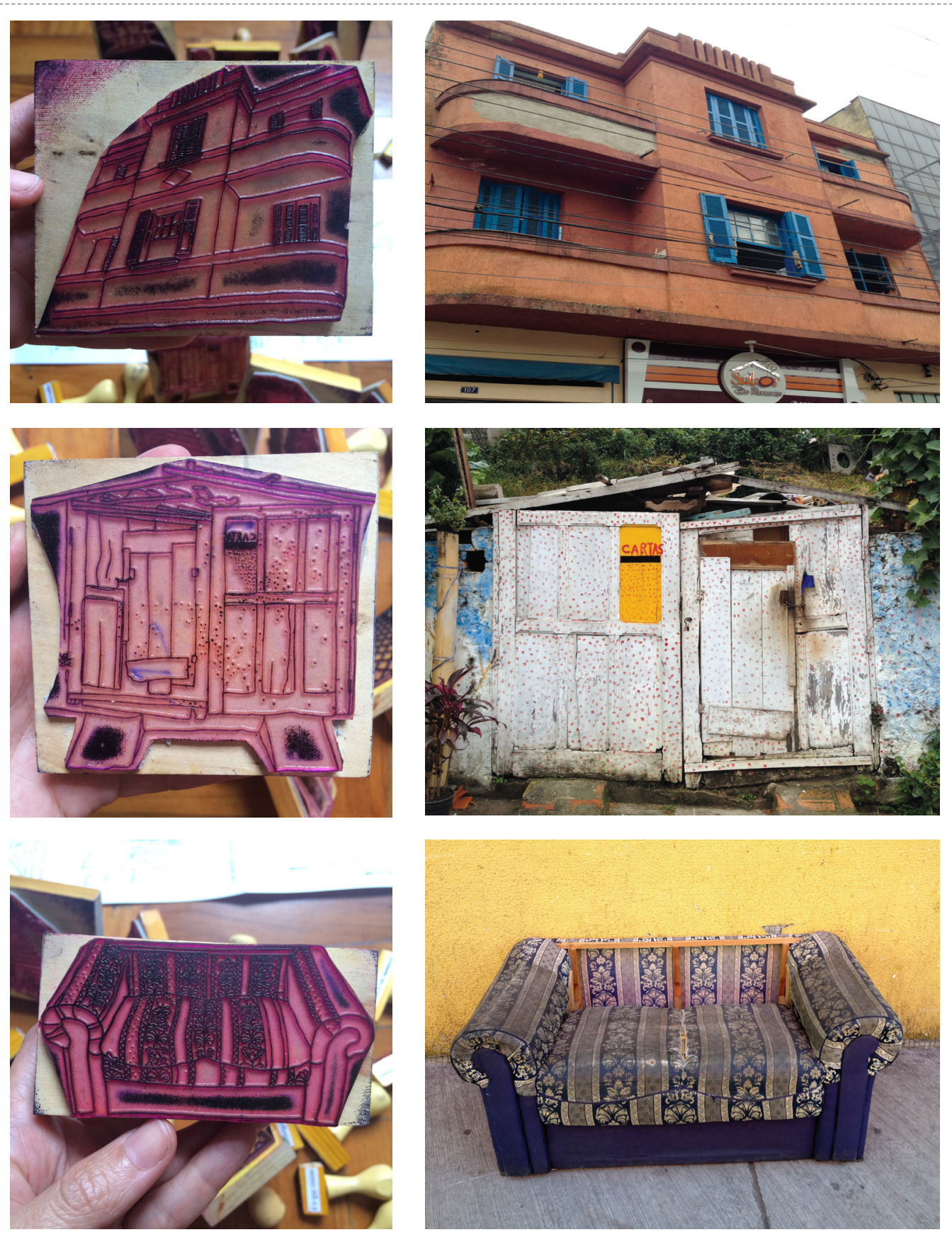

Figura 74 - Carimbos de Cidade Passo 

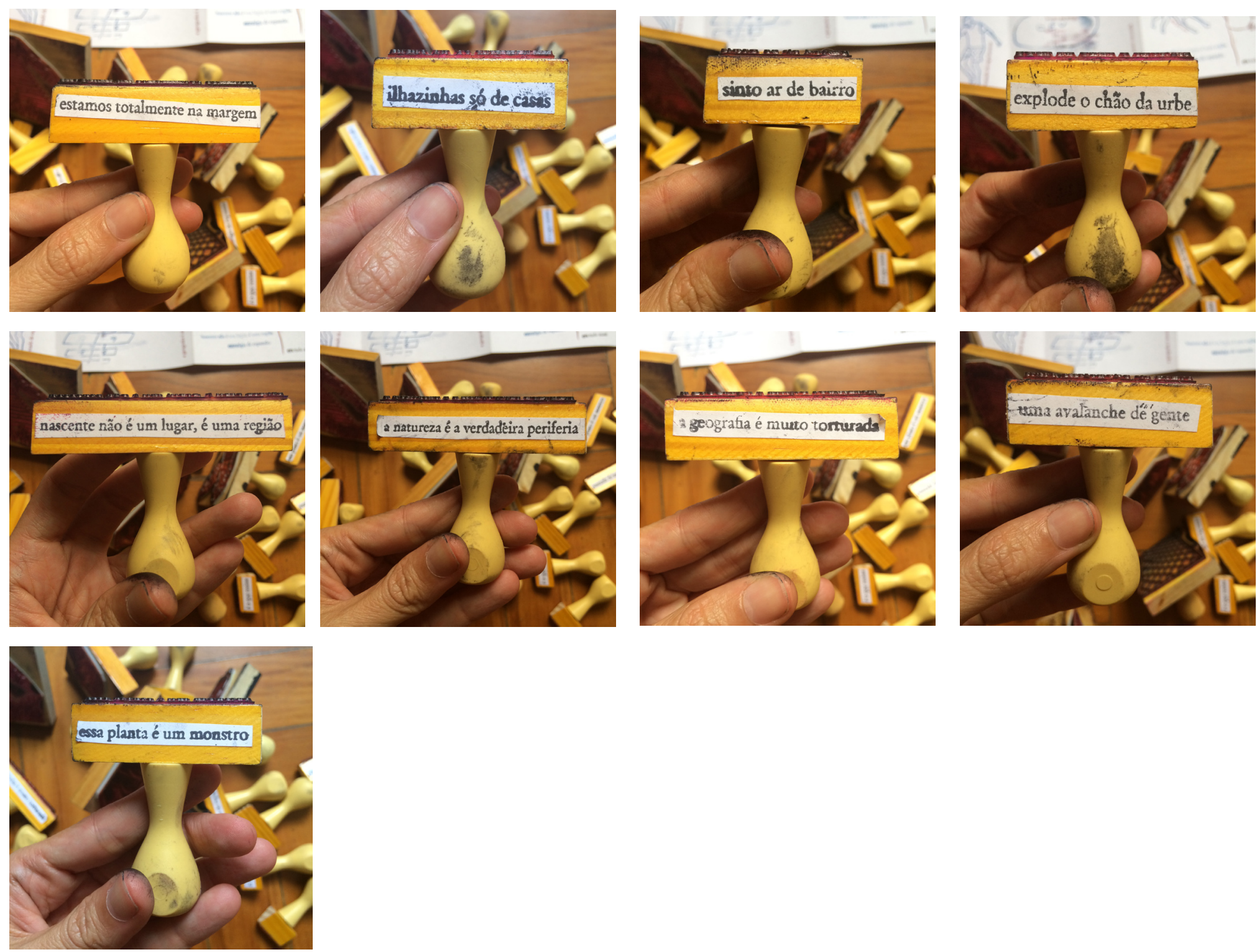

Figura 75- Carimbos de Cidade Passo 


\section{Para um novo começo}


O proposto com Cidade Passo foi um processo de corpo-a-corpo com a cidade, utilizando o caminhar como instrumento de "coleta de dados" (para utilizar uma expressão do design da informação). Nesta cartografia, o intuito não foi gerar conclusões e sim uma ativação de sensibilidades que, apesar de projetual, foi completamente aberta à intuição. Permeia todo o trabalho a crença de que o caminhar é um instrumento potente de leitura e escrita do espaço, capaz de promover um entendimento amplo do arquitetônico e do urbano na medida em que se presta a escutar e interagir diretamente na variabilidade do que é percorrido.

O designer que caminha, que erra - bem como o arquiteto, o etnógrafo e o artista expõe-se, lança-se ao desconhecido e torna-se assim um propositor de narrativas de cidade potentes, porque vividas, experimentadas e não baseadas em estatísticas puras e simples. "O errante não vê a cidade somente de cima, a partir da visão de um mapa, mas a experimenta de dentro; ele inventa sua própria cartografia a partir de sua experiência itinerante" (JACQUES, p. 24, 2012).

Jacques (2012) defende que as experiências errantes, quando narradas, em diversos formatos, desdobram a mesma em novas possibilidades a cada leitura. Vimos nas páginas anteriores uma série de exemplos de "corpocartografias", que perenizam vivências de corpo e conferem sentidos aventureiros, prismáticos, cambiantes aos trajetos. Podemos considerá-las como fragmentos de uma história de cidade não contada pelos grandes relatos hegemônicos e que não estão nos mapas oficiais.

Através dos diferentes trabalhos, imagens (fotos, filmes, cartografias), músicas ou escritos desses artistas, ou seja, através de suas narrativas errantes, é possível apreender o espaço urbano de outra forma, partindo do princípio de que os errantes questionam o planejamento e a construção dos espaços urbanos de forma crítica. O simples ato de errar pela cidade pode assim se tornar uma crítica ao urbanismo como disciplina prática de intervenção nas cidades (ibid, p. 30). 
O mapa pode ser uma forma de relato que serve ao sistema de poderes no sentido de escamotear as relações desiguais entre os diversos agentes e servir a projetos de mercantilização das cidades. Ao mesmo tempo, tem o potencial de ser um elemento desconstrutor de discursos de poder, propositor de reflexões amplas sobre o meio ambiente e a vida.

O arquiteto Pedro Fiori Arantes diz que uma proposta de "contramapa" tem a tarefa de expor o que é invisível. Tanto do lado das forças politico-econômicas mercantilistas e suas dinâmicas exploratórias quanto no sentido de tirar da invisibildade sujeitos políticos e seus territórios de ocupação que, em geral nos mapas, estão suprimidos, são tidos como áreas verdes ou as ruas não são registradas por que são informais.

(...) trazer esses sujeitos [invisibilizados] e nesse sentido humanizar a representação, incorporar histórias de vida individuais, coletivas, convergências, divergências, dissensos. É um mapa que se reporta à experiência vivida, por oposição a essa representação abstrata do capital e do Estado que os outros mapas impõem. É um exercício de tornar visível aqueles que são apagados da política e da condição de cidadãos. O mapa "anti-sistêmico", "contra-hegemônico", é o mapa que traz as evidências do que é apagado pelo outro mapa (ARANTES, 2012).

Renata Marquez aponta que a estética romântica é baseada em um isolamento social do criador artístico, uma disfunção no mundo funcional, uma "satisfação desinteressada" e uma "finalidade sem fim" que conduz à experiência do sublime. Por sua vez, a ciência moderna persegue a neutralidade e a objetividade e portanto esforça-se em separar o investigador do mundo que investiga por meio de um "olhar desincorporado", um olho de um corpo que utopicamente não faz parte do mundo, que se situa à distância, com o privilégio de ver uma suposta totalidade e de não se deixar distrair (MARQUEZ, 2009, p.18).

Cidade Passo caminhou numa direção inversa a esse paradigma uma vez que foi, sobretudo, uma experiência de contaminação, de entrega às alteridades do espaço. Foi uma 
escolha deliberada enquanto artista-designer de afetar-me, imergir em microssistemas, em cotidianidades de um trabalho etnográfico espontâneo.

Como este tipo de processo pode contribuir na formação de um conhecimento espacial? A prática da arquitetura, do urbanismo e do design não pode ser reduzida a índices numéricos, fatores econômicos, análises de gabinete uma vez que, como disse Milton Santos o espaço é "um resultado da inseparabilidade entre sistemas de objetos e sistemas de ações”(SANTOS, 2009, p.21). O conhecimento espacial é obrigatoriamente socioespacial e a proposição de situações experimentais aguça o olhar para questões, potencialidades e dinâmicas do mesmo, que não poderiam ser acessadas desde um lugar meramente estratégico.

O arquiteto dinamarquês Jan Gehl enfatiza em seu trabalho que a dimensão humana, vem sendo negligenciada por décadas no planejamento das cidades, ao passo em que as construções de edificios em grande escala e de vias para automóveis são priorizadas. Gehl defende que a boa qualidade "a nível dos olhos", no âmbito das cidades, deve ser considerada um direito humano básico.

A única abordagem bem sucedida para o projeto de grandes cidades para as pessoas deve considerar a vida e o espaço da cidade como ponto de partida. É o aspecto mais importante - e o mais difícil - e não pode ser deixado para mais tarde no processo. Se é fato que deve haver uma sequência, essa começa ao nível dos olhos e termina em uma vista aérea. Naturalmente, o melhor dos mundos é trabalhar com três escalas, ao mesmo tempo, de forma holística e convincente (GEHL, 2013, p. 198).

Francesco Careri defende que, para além da ampliação do repertório do indivíduo, o caminhar - e as narrativas que resultam desta experiência - revela-se útil à arquitetura como instrumento cognitivo e projetual, como forma de visibilizar a cidade. Neste sentido, a errância urbana deveria ser considerada como um valor em vez de um equí- 
voco. Em paralelo à grandes narrativas, à História oficial da cidade, as micronarrativas feitas pelos caminhantes podem servir para disseminar uma consciência do espaço e seus usos para além dos discursos oficiais.

O livro inscreve na cultura modos de olhar o mundo, construtos que trabalham na infinita tarefa de indagação, tradução e imaginação do conhecimento adquirido. É o design que confere materialidade, visibilidade e acessibilidade a esses conteúdos, na medida em que transforma processos sensíveis em projeto, em objeto legível. $\mathrm{Na}$ medida em que o livro (em seu caráter de mapa, no sentido deleuziano) é fruido, usado, transforma-se em dispositivo ativador de novas sensibilidades.

A fala que segue, de Francesco Careri, sintetiza o que acredito ser uma potência real do processo vivido em Cidade Passo:

O que se pode é indicar o caminho como um instrumento estético capaz de descrever e modificar os espaços metropolitanos que muitas vezes apresentam uma natureza que ainda deve ser compreendida e preenchida de significados, antes que projetada e preenchida de coisas. Assim, o caminhar revela-se um instrumento que, precisamente pela sua intrínseca característica de simultânea leitura e escrita do espaço, se presta a escutar e interagir na variabilidade desses espaços, a intervir no seu contínuo devir com uma ação sobre o campo, no aqui e agora das transformações, compartilhando desde dentro as mutações daqueles espaços que põem em crise o projeto contemporâneo. 


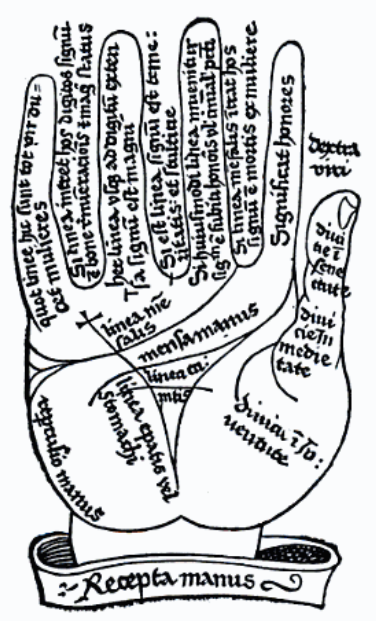




\section{Referências}

ALMEIDA, Sónia Vespeira. Antropologia e práticas artísticas em Portugal. Cadernos de Antropologia, v. 1, p. 73-83, 2013.

AFONSO, Ana Isabel. New graphics for old stories. Representation of local memories through drawings. (com desenhos de Manoel João Ramos) In Working Images, Visual Research and Representation in Ethnography. P. 72-89. London New York: Routledge, 2004.

ARANTES, Pedro Fiori. Entrevista concedida ao The Bartlett Development Planning Unit. Disponível em: < https://www. youtube.com/watch?v=FkiiAKlsQP4>. Acesso em: 26 de fevereiro de 2017.

BARBOSA, Lara Leite. Design sem Fronteiras: a relação entre o nomadismo e a sustentabilidade. São Paulo: Edusp/ FAPESP, 2012.

BARTHES, Roland. A câmara clara: nota sobre fotografia. Rio de Janeiro: Nova Fronteira, 1984.

BONSIEPE, Gui. Design, cultura e sociedade. São Paulo: Blucher, 2011.

CARERI, Francesco. Walkscapes. O caminhar como prática estética. São Paulo: Editora G. Gili, 2013.

CALLE, Sophie. Les Dormeurs. Paris: Actes Sud, 2000.

CAMART, Cécile. As estratégias editoriais de Sophie Calle: Livros de fotografias, fotorromance, livros de artista. In

Pós: Belo Horizonte, v. 5, n. 10, p. 112 - 129, novembro, 2015.

CARERI, Francesco. Walkscapes. O caminhar como prática estética. São Paulo: Editora G. Gili, 2013.

CERTEAU, Michel de. A Invenção do cotidiano 1. Artes de fazer. Petrópolis, RJ: Vozes, 2014.

CIDADE, Daniela Mendes. A cidade revelada. A fotografia como prática de assimilação da arquitetura. Dissertação (mestrado em teoria, história e crítica da arquitetura), Uiversidade Federal do Rio Grande do Sul, Porto Alegre, 2002.

COSTA Jr., Hely Geraldo. Entre arte e design. Sobre afectos e afecções na obra de Guto Lacaz. Dissertação (mestrado em artes) Universidade Federal de Minas Gerais, Belo Horizonte, 2009.

DAVILA, Thierry. Marcher, créer. Déplacements, flâneries, dérives dans l'art de la fin du XX siècle. Paris: Editions du Regard, 2002.

DEBORD, Guy. A Sociedade do Espetáculo. Rio de Janeiro: Contraponto, 1997.

DEBORD, Guy. Informe sobre la construcción de situaciones y sobre las condiciones de la organización y la acción de la tendencia situacionista internacional, 1957. Disponível em: <http://www.sindominio.net/ash/informe.htm> Acesso em: 8 de julho de 2016. 
DELEUZE, Gilles; GUATTARI, Félix. Mil platôs. Capitalismo e Esquizofrenia, vol.1. São Paulo: Editora $34,1995$.

DELEUZE, Gilles; GUATTARI, Félix. Mil platôs. capitalismo e esquizofrenia, vol.3. São Paulo: Editora 34, 1996.

DELEUZE, Gilles; GUATTARI, Félix. Mil platôs. capitalismo e esquizofrenia, vol.4. São Paulo: Editora 34, 1997.

DELEUZE, Gilles; GUATTARI, Félix. Mil platôs. Capitalismo e Esquizofrenia, vol 5. São Paulo: Editora 34, 2012.

DELEUZE, Gilles; PARNET; Claire. Diálogos. São Paulo: Escuta, 1998.

DELEUZE, Gilles; e GUATTTARI, F. O que é a filosofia? São Paulo: Editora 34, 1992.

ESCOBAR, Ticio. Arte Latinoamericano: una discusión de su concepto. In. 100 artistas latino-americanos. Exit Publicaciones, Madrid, 2010.

EVANS, James; JONES, Phill. The walking interview: Methodology, mobility and place. In Applied Geography, n. 31, p. 849 - 858, 2011.

FLÜSSER, Vilém. O Mundo Codificado. São Paulo: Cosac Naify, 2007.

FONTES, Adriana Sansão. Amabilidade urbana: A qualidade do espaço-tempo da intervenção temporária. In: Cadernos Proarq, Rio de Janeiro, n. 17, p. 22-41, 2011.

GEHL, Jan. Cidades para pessoas. 2a ed. São Paulo: Perspectiva, 2013.

GUY, E. Debord(er) la carte. Disponível em:< http://strabic.fr/Debord-er-la-carte\#nb6-2>. Data de acesso: 7 de agosto de 2014

INGOLD, Tim. Lines. A brief history. Routledge: New York, 2007.

JACQUES, P.B. Elogio aos Errantes. Salvador: EDUFBA, 2012.

KASTRUP, Virgínia. O funcionamento da atenção no trabalho do cartógrafo. In Revista Psicologia \& Sociedade; 19(1): 15-22, jan/abr. 2007

LYRA, Luciana de Fátima R.P. de Da artetnografia: máscara mangue em duas experiências performáticas. Relatório científico de pós-doutorado em antropologia. Universidade de Campinas, Campinas, 2013.

LYNCH, K. A imagem da cidade. 3a Ed. São Paulo : Editora WMF Martins Fontes, 2011.

MADERUELO, Javier. La idea de espacio en la arquitectura y el arte contemporáneos 1960 - 1989. Madrid, Ediciones Akal: 2008.

MARQUEZ, Renata Moreira. Geografias portáteis: arte e conhecimento espacial. Tese (doutorado em geografia). Instituto de Geociências, Universidade Federal de Minas Gerais, Belo Horizonte, 2009.

MESQUITA, A.L. Mapas dissidentes. Proposições sobre um mundo em crise (1960 - 2010). 2013.248 f. Tese (doutorado em Filosofia e Letras), Universidade de São Paulo, São Paulo, 2013. 
MONNET, Nadja. Flanâncias Femininas e etnografia. In Redobra, n. 11. p 218-234, 2014.

NOLLE, Christian. Books of Warfare: The Collaboration between Guy Debord \& Asger Jorn from 1957-1959, http://virose. pt/vector/b_13/nolle.html, acessado no dia 10 de março de 2016

NOVAES, Sylvia Caiuby (org). Entre Arte e Ciência. A fotografia na antropologia. São Paulo: Editora da Universidade de São Paulo, 2015.

OBRIST, Hans Ulrich. Mapping it out. An alternative atlas of contemporary cartographies. Londes: Thames \& Hudson, 2014

PENA, Rodolfo F. Alves. Projeção de Mercator; Brasil Escola. Disponível em < http://brasilescola.uol.com.br/geografia/projecao-mercator.htm>. Acesso em 25 de abril de 2016.

PRECIOSA, Rosane. Rumores discretos da subjetividade. Porto Alegre: Sulina; Editora da UFRGS, 2010.

RICOEUR. Paul. A memória, a história, o esquecimento. Campinas: Editora da Unicamp, 2007.

ROLNIK, Suely. Cartografia Sentimental: Transformações contemporâneas do desejo. Porto Alegre: Sulina; Editora da UFRGS, 2014.

SANTOS, Milton. A natureza do espaço: técnica e tempo, razão e emoção. São Paulo: Editora da Universidade de São Paulo, 2009. SANTOS, Milton. Elogio da lentidão. São Paulo: Folha de São Paulo, 11 de março de 2001.

TAUSSIG, Michael. I swear I saw this: drawings in fieldwork notebooks, namely my own. The University of Chicago Press, Chicago, 2011.

VISCONTI, Jacopo Crivelli. Novas derivas. São Paulo: Editora WMF Martins Fontes, 2014. 